\title{
IMPACTS OF CLIMATE CHANGE ON VEGETATION DISTRIBUTION NO. 2 - CLIMATE CHANGE INDUCED VEGETATION SHIFTS IN THE NEW WORLD
}

\author{
HUFNAGEL, L. ${ }^{1}{ }^{*}$ - GARAMVÖLGYI, Á. ${ }^{2}$ \\ ${ }^{I}$ Szent István University, Faculty of Agricultural and Environmental Science, Gödöllö, H-2100, \\ Páter Károly utca 1., Hungary (phone: +36-1-294-9875) \\ ${ }^{2}$ Department of Mathematics and Informatics, Faculty of Horticulture, Corvinus University of \\ Budapest, \\ H-1118 Budapest, Villányi út 29-43., Hungary \\ (phone: +36-1-482-6261) \\ *Corresponding author \\ e-mail: leventehufnagel@gmail.com \\ (Received $24^{\text {th }}$ Apr 2014; accepted $22^{\text {nd }}$ July 2014)
}

\begin{abstract}
After giving an overview of climate change induced vegetation shifts in the Palearctic region in our previous paper, in this article we review literature available in Web of Science on North and South America. We study different geographical regions such as Canada, Alaska, California, Southwestern, Eastern and Southeastern USA, the Great Lakes region, the Great Plains, intermontane basins and plateaus, Rocky Mountains and the Cascades as well as Central and South America. We summarize main results of relevant field studies, experiments and model simulations. Predicted environmental changes include temperature increases, altering precipitation patterns, droughts, permafrost thaw and ground subsidence in arctic regions, enhanced El Niño Southern Oscillation, sea level rise, increasing salinity of the vadose zone, snowpack declines and various disturbances. All vegetation types are affected by these changes, to the most important phenomena belong e.g. reduction of arctic and alpine communities, decreasing area of taiga, shrub encroachment in tundra areas, northward expansion of the tree line, reduction in wetland areas, invasion, altering forest regeneration patterns, decrease in dominance of conifer species, increased cover of salt-tolerant plant species in tidal marshes, expansion of grassland, compositional and structural changes of grasslands and forests, drying up of bogs, landward migration of mangroves, savannification of forests, expansion of chaparral as well as upward migration of species in the mountains.
\end{abstract}

Keywords: global warming, vegetation distribution, biome, vegetation zone, plant community

\section{Introduction}

Terrestrial ecosystems are greatly affected by climate, particularly temperature and precipitation (Holdridge, 1947; Woodward, 1987). Increases in atmospheric trace gas concentrations could warm the global average temperature significantly by the end of the $21^{\text {st }}$ century (Overpeck et al., 1991). Increased temperatures would reduce the supply of soil moisture by reducing the volume of snow and increasing winter runoff, and increase the potential evapotranspiration. These processes would likely produce widespread drought-induced dieback (Neilson et al., 1992). Besides, climate change models forecast not only global warming but alteration of precipitation regimes affecting timing, frequency and intensity of precipitation events as well (Easterling et al., 2000; NAST, 2000; IPCC, 2001). Drought frequency and severity are predicted to increase across numerous continental interiors (Müller et al., 2005). Alteration of precipitation patterns has the potential to cause major changes in vegetation, soils, 
biodiversity and ecological processes in terrestrial ecosystems (Neilson et al., 1989; Brown et al., 1997; Ehleringer et al., 2001).

As climatic zones change due to climate change, so too will the productivity, composition, diversity and spatial extent of ecosystems as well as plant dominance patterns and community evenness (Suffling \& Scott, 2002; Bates et al., 2006; Flantua et al., 2007; Kardol et al., 2010). As current ecosystems are temporary associations, they may re-sort into different assemblages as a response to climate change (Anderson et al., 1998). Species distributions are already affected by climate change (Hauer et al., 1997; Morin \& Chuine, 2005; Morin et al., 2008; Rehfeldt et al., 2002; Hamann \& Wang, 2006; Gómez-Mendoza \& Arriaga, 2007; Pucko et al., 2011), and large-scale (altitudinal or latitudinal) biogeographical shifts in vegetation are predicted in response to the altered precipitation and temperature regimes (Scheller \& Mladenoff, 2005; Parmesan, 2006; Adams et al., 2009; Feeley et al., 2011; Fridley \& Wright, 2012; Alo \& Wang, 2008; Valle-Díaz et al., 2009; Kupfer \& Cairns, 1996). Projections of the response of the biosphere to global climatic change indicate $50 \%$ to $90 \%$ spatial displacement of extratropical biomes. The mechanism of spatial shift could be dominated by either competitive displacement of northern biomes by southern biomes, or drought-induced dieback of areas susceptible to change (Neilson et al., 1992). These shifts have profound ecological impacts and are an important climate-ecosystem feedback through their alteration of carbon, water, and energy exchanges of the land surface (Adams et al., 2009).

Secondary interactions (such as indirect effects of climate change on fire intensity and ozone pollution, altered disturbance regimes) also play an important role in vegetation change (Malanson \& Westman, 1991; Beckage et al., 2006). Environmental responses to global change are likely to be nonlinear and thus complex (Malanson, 2001). This results in the fact that surprises are more likely than precise prediction. Besides, species interactions also strongly influence responses to changing climate and may overturn direct climatic effects and reverse community trajectories (Suttle et al., 2007).

Climate predictions suggest that changes in species' distributions will accelerate in the future (Morin et al., 2008; Allen \& Breshears, 1998). Theoretically, long-range migration can play a significant role in species distribution (He et al., 2003). If climate changes at a moderate rate, species will be able to migrate and track suitable conditions that match their niche (Hewitt, 1996, 2000; Ackerly, 2003). However, the rate of human-induced climate change may exceed the physiological capabilities of some species to migrate to areas with tolerable climate limits (Anderson et al., 1998). Species which are unable to keep pace with changing range limits may experience a reduction in population size and exist in climatic disequilibrium (Dyer, 1994; Dyer, 1994b). Besides, even if a population disperses to a new region with a favourable climate, interactions with other species may prevent its establishment and further spread (Ibanez et al., 2009). Increasing temperatures and severe droughts may cause high mortality in the trailing range edge of the distribution of mountain or high-latitude plant communities, driving the species to rapid range shifts and range boundary disturbances, species replacement, and community alterations (Lenoir et al., 2008; Jump et al., 2009; Mátyás, 2010). Furthermore, human dominated landscapes will function as barriers to migration for many species (Suffling \& Scott, 2002). As a consequence, many species have already suffered reductions in habitable area due to recent climate change (Parmesan, 2006). Northern ecosystems may be particularly vulnerable to climate change due to 
greater-than-average predicted temperature increases at higher latitudes (Körner \& Larcher, 1988; Kattenberg et al., 1996).

Species respond individually to climate change (Gleason, 1926; Chuine, 2001), as all of them have different climatic tolerances (Eeley et al., 1999). Thus, predicted distribution shifts are species-specific just as they were during past climate changes (Davis, 1989; Graham, 1992; Webb, 1992). As their dispersal rate also differs, different species will not face the same risks due to climate change (Morin et al., 2008; He et al., 2003). Changes in plant community composition will result from shifting competitive abilities and seed dispersal mechanisms of individual species (Malanson \& Westman, 1991; Davis, 1986; Webb, 1986; Malanson, 1993). Several authors suggest that forest communities do not respond as units (Davis, 1981; Webb, 1987; Huntley, 1991), thus, formation of novel communities can be expected as well (Pucko et al., 2011). However, permanent vegetation change will occur only if not only tree mortality patterns but tree recruitment patterns are also affected (Suarez \& Kitzberger, 2008). Pucko et al. (2011) add that future species responses may become increasingly divergent as the magnitude of climate change increases since species-specific environmental thresholds will be reached and the synergistic effects of multiple anthropogenic perturbations will rise.

After discussing climate change induced vegetation shifts in the Palearctic region in our former article (Garamvölgyi \& Hufnagel, 2013), in this paper we summarize observed and simulated changes of community composition and range shifts in America, based on literature available in Web of Science. Results are presented according to geographical regions, focusing on main trends and phenomena.

\section{Projections for North America in general}

Simulations for North American tree species for the $21^{\text {st }}$ century by Morin et al. (2008) show that local extinctions may occur in the south of species ranges, and colonisation of new habitats is expected in the north, although these are limited by dispersal ability for most species. The loss of habitats southward will be mostly due to increased drought mortality and decreased reproductive success, while northward colonisation will be primarily promoted by increased probability of fruit ripening and flower frost survival. Morin et al. (2008) also concluded that local extinction may proceed at a slower rate than forecasted so far because of the local adaptation of the species.

Shafer et al. (2001) also conducted simulations for tree and shrub species in North America for 2090-2099 and found large changes in the potential distribution of species (Table 1). They also showed that shifts are mainly driven by increases in temperature and changes in the moisture index, and that the pattern of vegetation response to climate change is strongly mediated by topography. According to their results, ranges will shift not only northward and upward in elevation but in all directions. Simulated potential range expansions in eastern North America, where topographic relief is relatively low, occur in a northward direction with increases in the mean temperature of the coldest month. Simulated west-to-east potential range changes along the prairie-forest border are primarily related to changes in the moisture index. In contrast, in western North America, the simulated patterns of change in potential ranges are more disjunct, often with large distances occurring between a species' current distribution and simulated areas of future potential habitat (e.g. in the case of Pseudotsuga menziesii, Douglas fir). 
Potential distributions of Betula papyrifera (paper birch) and Picea glauca (white spruce) are simulated to expand northward. However, while the southern range limit of Picea glauca contracts northward, the southern range limit of Betula papyrifera expands southward in the Rocky Mountains. As for the boreal tree species, relatively large areas of their current range remain suitable under future climate scenarios. In the mid-continent, potential ranges of both species are simulated to contract due to decreases in the moisture index.

In the intermountain region of the US, potential range of Artemisia tridentata (big sagebrush) is expected to shift northward in response to increases in the mean temperature of the coldest month, leading to a significant contraction of its current range. Increases in fire frequency under future climate scenarios could also facilitate the simulated potential range contractions because Artemisia tridentata does not resprout following fire events (Smith et al., 1997).

The simulated potential range of Yucca brevifolia (Joshua tree) is fragmented and displaced northward and eastward. Two desert species, Carnegiea gigantea (saguaro) and Larrea tridentata (creosote bush) also show significant potential range shifts. Potential range of Larrea tridentata is predicted to expand throughout the intermountain regions of the West into areas currently dominated by Artemisia tridentata. The potential range of Carnegiea gigantea is simulated to expand as well, with new habitats occurring both west and east of its current range. In the mountains of western Mexico, increased temperatures coupled with a lower moisture index may lead to potential range contractions of Pseudotsuga menziesii and Pinus ponderosa (ponderosa pine).

In the Pacific Northwest, potential ranges of high-elevation species, such as Abies amabilis (Pacific silver fir), are simulated to contract due to increases in temperature. Many Pacific Northwest species are simulated to shift from west of the Cascades and northern Sierras to the east of these mountain ranges. Affected are both conifer species, such as Pseudotsuga menziesii and Taxus brevifolia (Pacific yew), as well as broadleaf species, such as Alnus rubra (red alder) and Quercus garryana (Oregon white oak). Species which can tolerate relatively warm and dry conditions, such as Pinus ponderosa and Quercus lobata (California white oak) are simulated to expand into the area west of the Cascades and northern Sierras. Shafer et al. (2001) also concluded that many new areas of suitable bioclimatic habitat will be small and relatively isolated under the future climate scenarios, thus habitat fragmentation resulting from human land-use activities will have a significant impact on the abilities of species to disperse in response to changing climate conditions.

Table 1. Simulated changes in distribution of certain species for 2090-2099 (Shafer et al., 2001)

\begin{tabular}{|l|l|l|}
\hline \multicolumn{1}{|c|}{ Species } & \multicolumn{1}{c|}{ Direction of range shift } & \multicolumn{1}{c|}{ Change of range size } \\
\hline Betula papyrifera & northward, southward & expansion \\
\hline Picea glauca & northward & contraction, expansion \\
\hline Artemisia tridentata & northward & contraction \\
\hline Yucca brevifolia & northward, eastward & \\
\hline Carnegiea gigantea & westward, eastward & expansion \\
\hline Pseudotsuga menziesii & & contraction (in Mexico) \\
\hline Pinus ponderosa & & contraction (in Mexico) \\
\hline Abies amabilis & & contraction \\
\hline Pseudotsuga menziesii & eastward (in the Pacific NW) & \\
\hline
\end{tabular}




\begin{tabular}{|l|l|l|}
\hline Taxus brevifolia & eastward & \\
\hline Alnus rubra & eastward & \\
\hline Quercus garryana & eastward & \\
\hline Pinus ponderosa & westward (in the Pacific NW) & \\
\hline Quercus lobata & westward & \\
\hline
\end{tabular}

\section{Canada}

\section{Projected changes in climate}

Temperature change in continental areas of Canada may be twice the global average at $50^{\circ} \mathrm{N}$ and 3.5 times at $80^{\circ} \mathrm{N}$ (Etkin et al., 1998). On a countrywide scale models predict increased temperatures, but these are quite variable on a regional scale (Bouchard, 2001). Suffling and Scott (2002) observed a universal warming trend in all national parks of Canada, with greater temperature increases in winter, and most dramatically in the arctic region. As for precipitation, there is generally a large increase in winter in the Prairie parks, and especially large winter increases are seen in the arctic region. However, two mainland arctic parks are predicted to experience decreased winter precipitation. Furthermore, decreased summer precipitation is projected for all regions from Ontario westward. According to Bouchard (2001), increased aridity could be critical in some Prairie areas. Extreme events could be more frequent, with serious negative effects. In northern areas, warming trends will provoke permafrost degradation, development of thermokarsts and soil instability. A sea-level rise is anticipated as well, which will make the coasts of Prince Edward Island, New Brunswick and Nova Scotia vulnerable to submersion risks.

\section{Projected changes in vegetation}

In Canada, climate change represents an unprecedented challenge to national parks (Scott et al., 2002). Biomes are expected to shift northward (Bouchard, 2001) and according to modelling results, $37-48 \%$ of Canada's protected areas could experience a substantial change in terrestrial biome type under doubled atmospheric $\mathrm{CO}_{2}$ conditions (Lemieux \& Scott, 2005). In simulations by Scott et al. (2002), a novel biome type appeared in more than half of the national parks and greater than $50 \%$ of all vegetation grid boxes changed biome type. The proportional representation of tundra and taiga/tundra declined, while more southerly biomes (temperate forests and savanna/woodland) increased. Results for boreal forest varied among the climate change scenarios. In contrast, Schneider et al. (2009) suggest that 12-21\% of Alberta's boreal region will be converted to parkland and grasslands will shift northward into much of the existing parkland.

Suffling and Scott (2002) studied expected changes in Bruce Peninsula National Park and found that the anticipated drop in water level will dry the marshes and fens bordering the shoreline in many areas and dryland plants may colonise the upper fringes of the marsh complex. Decreased summer and autumn precipitation will result in a lower water table and increased drought conditions. As a consequence, marsh complexes will dry out more often and may be colonised by white cedar (Thuja occidentalis), resulting in a loss of plant diversity. Many plant communities may shift to more xeric species, while other species with high drought tolerance may thrive in the new conditions (e.g. Hymenoxis acaulis, angelita daisy). According to simulations by 
Lenihan and Neilson (1995), temperate summergreen vegetation community will remain dominant or possibly shift to mixed grass prairie vegetation and invasion by southern exotic species is expected as well.

For Atlantic Parks, Suffling and Scott (2002) predict the expansion of mixed and deciduous forest and the reduction of boreal forests, as well as reduction, isolation and extirpation of arctic-alpine species and communities. In Great Lakes - St. Lawrence Basin Parks, reduction of wetland areas, expanding mixed and deciduous forest, less boreal forest and expansion of southern exotics are expected. Hogenbirk and Wine (1991) also suggest that in mid-boreal wetlands, Eurasian species might dominate early successional communities due to the shift of seasonally flooded vegetation zones from flood-driven dynamics with cool and moist environmental conditions towards droughtand fire-driven dynamics with warmer and drier conditions. In Western Cordillera Parks, some alpine assemblages may disappear from mountain peaks, beside the latitudinal and altitudinal migration of ecozones. Loss of higher elevation alpine species is predicted for Pacific Parks as well, while in Arctic Parks the northward expansion of tree line is expected. Overall, the emergence of transitory ecological communities is predicted for the latter half of the $21^{\text {st }}$ century, however, ecosystem-level response to climate change will never be entirely predictable (Myers, 1995; Malcolm \& Markham, 1996).

\section{Role of fire and soils}

Distribution of boreal biome subzones in central Canada is largely governed by fire occurrence (Suffling, 1995). Forecasted rise in surface air temperatures and lower summer precipitation will likely lead to increased fire season length and area burned in forested regions (Stocks et al., 1998; Flannigan et al., 1998, 2000, 2005; Bélanger \& Pinno, 2008). The twofold increase in annual area burned in western North America in the last 40 years is probably linked to climate warming (Kasischke \& Stocks, 2000). Areas with dry macro- or microclimate or coarse-textured soils may be particularly susceptible to more frequent fire (Larsen, 1997). Due to this, Hogg and Hurdle (1995) assume that the Boreal Plain ecozone will shrink and give way to the Prairie ecozone. Bélanger and Pinno (2008) concluded that forests supported by sandy glacio-fluvial parent materials will be the first to be impacted. In contrast, stands supported by imperfectly or poorly drained glacio-lacustrine parent materials will be less susceptible to change because of more available water and nutrients, and will thus likely take a longer time for the transition from aspen to herbaceous vegetation. Forests supported by glacial till soils may be better buffered against warming and will likely resist invasion of herbaceous vegetation for longer compared to glacio-fluvial sites. The eventual shift from forest to herbaceous vegetation due to warming will also be favoured by increased fire disturbance (Axelrod, 1985; Romme et al., 1995). Lafleur et al. (2010) also assume that soil properties may constrain species migration, locally or regionally. Thus, these antagonistic forces (warming and soil characteristics) are likely to slow down potential tree migration in response to climate change. Because tree species respond individualistically to climate variables and soil properties, new tree communities are also likely to emerge.

At the forest-tundra boundary in eastern Canada, forest degradation is triggered by unusual fire events that interact with climatic stresses on conifer seed production and lead to failures of post-fire regeneration (Payette et al., 2001). Changes in fire interval may alter patterns of forest regeneration and cause shifts between deciduous- and 
conifer-dominated succession trajectories (Suffling, 1995; Frelich \& Reich, 1999; Dale et al., 2001). The same is confirmed by Johnstone and Chapin (2006), who found that young-burned stands had a much higher probability of regenerating to deciduous dominance than mature-burned stands in conifer-dominated boreal forests of northwestern Canada, despite the dominance of both groups by spruce (Picea mariana and Picea glauca) and pine (Pinus contorta) before the fire.

Concerning the rate of vegetation changes, Chapin et al. (2004) suggest these may be gradual at the northern forest limit or where seed dispersal limits species distribution. However, forest composition may be quite resilient to climate change in the central portions of a species range until some threshold is surpassed. At this point, changes can be rapid and unexpected, often causing a switch to very different ecosystem types.

\section{Changes in Arctic vegetation}

Several studies suggest that changes to Arctic vegetation such as increases in shrub abundance may result from increasing temperature (Stafford et al., 2000; Kaplan et al., 2003; Hassol, 2004; Johannessen et al., 2004; Tape et al., 2006; Notaro et al., 2007). According to observations, tall shrub tundra (vegetation dominated by tall shrubs, e.g. Alnus viridis, tall Salix spp. and Betula glandulosa) is encroaching into areas of dwarf shrub tundra (vegetation dominated by dwarf shrubs, e.g. Ledum decumbens, Vaccinium vitis-idaea, Arctostaphylos rubra, Rubus chamaemorus and sedges, e.g. Eriophorum vaginatum, Kobresia hyperborea) across the entire circumpolar region (Silapaswan et al., 2001; Sturm et al., 2001a; Stow et al., 2004; Tape et al., 2006). In the Mackenzie Delta region, the gradual transition between shrub and dwarf shrub suggests that this ecotone may be particularly sensitive to warming (Epstein et al., 2004a). Lantz et al. (2010) also found strong correlation between summer temperatures and vegetation type, which shows that increasing temperatures in the region (Lantz \& Kokelj, 2008) are likely to alter shrub abundance and shift the position of this ecotone. Plot level manipulations of temperature and nutrient availability further support predictions that warming will increase shrub dominance in the Low Arctic (Parsons et al., 1994; Chapin et al., 1995; Bret-Harte et al., 2001, 2002; Dormann \& Woodin, 2002; Walker et al., 2006). On the other hand, other vegetation communities such as lichen and moss decrease in cover fraction and biomass in response to warming (Olthof \& Latifovic, 2007). The expansion of tall shrub tundra is likely to have long-term impacts also on permafrost temperatures and terrain stability across the Low Arctic (Sturm et al., 2001a; Epstein et al., 2004b; Chapin et al., 2005; McGuire et al., 2006).

\section{United States of America}

\section{Changes in climate}

According to simulations by Lenihan et al. (2008a), relatively large increases in temperature and decreases in precipitation will be the general climatic trends in the eastern half of the United States. In contrast to the East, increases in precipitation accompanied by relatively small increases in temperature are the general projections for the West. Izaurralde et al. (2005) came to similar results. According to their simulations, large and contrasting regional changes can be expected in both precipitation and temperature. The extremes include significant warming in the north-eastern region of the country, almost no change in mean annual temperature in the south-eastern part, 
significantly drier conditions primarily in the southern half of the U.S. and the West may be much wetter than it is today. These predictions are surprising regarding the results of Grundstein (2009), who evaluated moisture trends between 1895-2006. Grundstein (2009) concluded that the eastern half of the country has been getting wetter in the $20^{\text {th }}$ century, even as temperatures have continued to increase in many areas. In particular, conditions have become wetter in the South, Northeast and East North Central regions as wetter conditions have expanded westward across the Central United States. On the contrary, many studies predict a drier climate in the central United States with an increasing likelihood of severe droughts (IPCC, 2001). Warming has been found across much of the United States, including the Northeast, West and northern Midwest, while a slight cooling trend was found in the Southeast ( $\mathrm{Lu}$ et al., 2005; Groisman et al., 2004; Lund et al., 2001). Precipitation has also shown positive trends across the United States (Groisman et al., 2004). The western half of the country has shown higher air temperatures but no consistent pattern in precipitation.

\section{Changes in vegetation}

According to their climate simulations, Izaurralde et al. (2005) suggest that climate change may increase net primary productivity slightly in the north-eastern quarter of the country and a bit southward from it, as well as in the coniferous forest of the Pacific northwest. Major losses may occur especially in the southeast. Overall, increases in net primary productivity can be expected in the west and decreases in the east.

However, the large number of future climate change scenarios used suggests that there is considerable uncertainty about possible future ecological impacts, particularly since some scenarios produce opposite sign ecological responses (Bachelet et al., 2001; Lenihan et al., 2008a). Although a number of model predictions have suggested that future climate change (including drought) will lead to extensive forest dieback and species migration (Leverenz \& Lev, 1987; Solomon, 1986; Pastor \& Post, 1988), such sensitivity has been questioned as well (Fischlin et al., 1995; Loehle, 1996; Loehle \& LeBlanc, 1996). Loehle $(1996,1998)$ suggested that current models of forest response might overestimate negative responses to climate change and concluded that forests would not suffer catastrophic dieback, but would instead be replaced gradually by faster growing tree species over longer time periods. Besides, according to simulations by Neilson and Drapek (1998), transient or stepwise changes in climate have beneficial rather than negative impacts on vegetation. They also concluded that moderate warming could produce increased vegetation growth over broad areas in the United States but greater warming could also produce large areas of drought stress. Simulations by Melillo et al. (1995) also resulted in both gains and losses of total forest area depending on the scenario. Investigating impacts of drought disturbance on forests of the United States, Hanson and Weltzin (2000) found that dramatic shifts in forest productivity and/or composition in the eastern United States as a result of intensification of drought over the next few decades are unlikely to be widespread. They concluded that it is still unclear which level of drought is required to kill or severely constrain growth of mature trees. However, forests growing in shallow soils with reduced water storage capacity would respond more than forested regions with annual late-season droughts. In contrast, Williams et al. (2000) suggest that significant displacement of biome boundaries can occur even in response to rather moderate warming.

It is also still unclear, just like in Europe (Garamvölgyi \& Hufnagel, 2013), whether communities will be able to keep pace with changing climate. Davis and Shaw (2001) 
argue that migration and adaptation would be hampered by the unprecedented rates at which climate appears to be changing in combination with ongoing changes in land use. According to Izaurralde et al. (2005), simulated land use changes are expected to be the most dramatic in the West.

Grundstein (2009) found that over the period 1895-2006, the most dramatic change has occurred across the Midwestern prairie peninsula (previously classified as tall grass prairie), where the wetter conditions have lead to a westward expansion of conditions favourable for oak-hickory-pine vegetation. Oak-hickory-pine has expanded into the South as well, where it replaces loblolly pine (Pinus taeda). Similarly, conditions suitable for tall grass have expanded westward into areas previously classified as short grass.

Bachelet et al. (2001) simulated vegetation distribution in the United States for the end of the $21^{\text {st }}$ century and came to controversial results. Over $40 \%$ of the coniferous forests are replaced by savannas under one of the scenarios, however, under all other scenarios, coniferous forests expand slightly. Temperate deciduous forest shifts to more northern locations and is replaced by either the southeast mixed forest or savannas under most scenarios. Northeast mixed forests are replaced by either savannas or the northward-shifting temperate deciduous forest in the Great Lakes region, due to warmer and drier climatic conditions. Southeast mixed forests are replaced mostly by savannas or partially by grasslands under the two warmer scenarios. However, these savannas may recover to forests by the end of the $21^{\text {st }}$ century. Tropical forests appear as a new vegetation type mostly in Louisiana, along the Gulf Coast in the Southeast, where they replace the original southeast mixed forest. The area covered by all forest types tends to decrease by the end of the $21^{\text {st }}$ century under the warmest scenarios, however, moderately warm scenarios produce increases in forest area of about $20 \%$. As for shrubland area, decreases are simulated under most scenarios, except for some, where shrubs replace grasses in areas of the Great Plains. Most shrubland losses occur in the Great Basin, where increased precipitation drives the replacement of shrubs by savannas. Savannas are simulated to increase by more than $50 \%$ under warm scenarios, however, they may also decrease according to another model. The area occupied by grasslands may remain stable, increase or decrease. Simulations for the western United States show $60 \%$ or greater reductions in the area of deserts under most scenarios due to significantly increased precipitation, a $20 \%$ increase in desert area is predicted only under the warmest scenario. Boreal forests in the Northeast shift northwards, and taigatundra and tundra are expected to decrease by more than $80 \%$ by the end of the $21^{\text {st }}$ century, due to increases in temperature. Western coniferous forests increase in area in most simulations. Overall, Bachelet et al. (2001) observed the same trends which are typical in Europe (Garamvölgyi \& Hufnagel, 2013): warming produces a northward shift of the various eastern forest types and an altitudinal shift of the taiga-tundra and tundra vegetation types. However, steep mountain slopes with unstable or poorly developed soils may limit the upslope migration of forests.

Bachelet et al. (2001) also concluded that forest areas are more sensitive than nonforest areas to potential future temperature increases. This is confirmed by the prediction according to which an average annual temperature increase of $4.5^{\circ} \mathrm{C}$ could produce a reduction in vegetation density over about $50 \%$ of US forest lands, while the remaining lands would experience increased growth. An overall increase can be expected in vegetation density with moderate warming, resulting in forest expansion across the United States. However, greater warming can lead to lower vegetation 
density and conversions of forests to savannas and grasslands. Neilson and Drapek (1998) came to the same result, suggesting that an early green-up may be possible in response to a moderate warming, followed later by vegetation density declines due to temperature-induced droughts. According to Bachelet et al. (2001), biomes that appear most sensitive to elevated temperatures include the temperate deciduous forest and the southeast mixed forest. Conifer forests show some indication of increased sensitivity with increasing temperature, but their overall response is less clear.

Table 2. Simulated changes in vegetation in the U.S. by the end of the 21st century (Bachelet et al., 2001)

\begin{tabular}{|c|c|c|c|}
\hline Vegetation type & Model & Scenario & $\begin{array}{c}\text { Character of } \\
\text { change }\end{array}$ \\
\hline \multirow{3}{*}{ coniferous forest } & \multirow{2}{*}{ MAPSS } & UKMO & $\begin{array}{l}\text { reduction, replaced } \\
\text { by savannas }\end{array}$ \\
\hline & & $\begin{array}{l}\text { all except UKMO } \\
\text { and GISS }\end{array}$ & expansion \\
\hline & $\mathrm{MC1}$ & CGCM1 & expansion \\
\hline \multirow[t]{4}{*}{$\begin{array}{c}\text { temperate deciduous } \\
\text { forest }\end{array}$} & \multirow[t]{2}{*}{ MAPSS } & $\begin{array}{l}\text { all except } \\
\text { HADCM2SUL }\end{array}$ & $\begin{array}{l}\text { reduction, } \\
\text { northward shift, } \\
\text { replaced by } \\
\text { southeast mixed } \\
\text { forest or savannas }\end{array}$ \\
\hline & & HADCM2SUL & expansion \\
\hline & \multirow{2}{*}{$\mathrm{MC1}$} & CGCM1 & reduction \\
\hline & & HADCM2SUL & expansion \\
\hline \multirow{4}{*}{$\begin{array}{c}\text { northeast mixed } \\
\text { forest }\end{array}$} & \multirow[b]{2}{*}{ MAPSS } & UKMO, GFDL & $\begin{array}{l}\text { reduction, replaced } \\
\text { by savannas }\end{array}$ \\
\hline & & $\begin{array}{l}\text { all except UKMO } \\
\text { and GFDL }\end{array}$ & $\begin{array}{l}\text { reduction, replaced } \\
\text { by temperate } \\
\text { deciduous forest }\end{array}$ \\
\hline & \multirow{2}{*}{$\mathrm{MC1}$} & CGCM1 & reduction \\
\hline & & HADCM2SUL & expansion \\
\hline \multirow{4}{*}{$\begin{array}{c}\text { southeast mixed } \\
\text { forest }\end{array}$} & \multirow{3}{*}{ MAPSS } & $\begin{array}{l}\text { UKMO, CGCM1, } \\
\text { GFDL }\end{array}$ & $\begin{array}{l}\text { reduction, replaced } \\
\text { by savannas }\end{array}$ \\
\hline & & UKMO, CGCM1 & $\begin{array}{l}\text { reduction, replaced } \\
\text { partially by } \\
\text { grasslands }\end{array}$ \\
\hline & & $\begin{array}{l}\text { all except } \\
\text { HADCM2SUL }\end{array}$ & $\begin{array}{l}\text { reduction, replaced } \\
\text { by tropical forest }\end{array}$ \\
\hline & $\mathrm{MC1}$ & & stable \\
\hline \multirow{2}{*}{ tropical forest } & MAPSS & $\begin{array}{l}\text { HADCM2SUL, } \\
\text { CGCM1 }\end{array}$ & expansion \\
\hline & $\mathrm{MC} 1$ & $\begin{array}{l}\text { HADCM2SUL, } \\
\text { CGCM1 }\end{array}$ & expansion \\
\hline shrubland & MAPSS & $\begin{array}{l}\text { all except UKMO } \\
\text { and } \\
\text { HADCM2SUL }\end{array}$ & $\begin{array}{l}\text { reduction, replaced } \\
\text { by savannas }\end{array}$ \\
\hline
\end{tabular}




\begin{tabular}{|c|c|c|c|}
\hline & $\mathrm{MC} 1$ & $\begin{array}{l}\text { HADCM2SUL, } \\
\text { CGCM1 }\end{array}$ & expansion \\
\hline \multirow{4}{*}{ grassland } & \multirow{3}{*}{ MAPSS } & $\begin{array}{l}\text { UKMO, } \\
\text { HADCM2SUL }\end{array}$ & $\begin{array}{l}\text { reduction, replaced } \\
\text { by shrubland }\end{array}$ \\
\hline & & UKMO & expansion \\
\hline & & HADCM2SUL & $\begin{array}{l}\text { reduction, replaced } \\
\text { by savannas }\end{array}$ \\
\hline & $\mathrm{MC1}$ & $\begin{array}{l}\text { HADCM2SUL, } \\
\text { CGCM1 }\end{array}$ & reduction \\
\hline \multirow[t]{2}{*}{ savanna } & MAPSS & $\begin{array}{l}\text { UKMO, CGCM1, } \\
\text { GFDL, } \\
\text { HADCM2SUL }\end{array}$ & expansion \\
\hline & $\mathrm{MC1}$ & $\begin{array}{l}\text { HADCM2SUL, } \\
\text { CGCM1 }\end{array}$ & reduction \\
\hline \multirow{3}{*}{ desert } & \multirow[t]{2}{*}{ MAPSS } & $\begin{array}{l}\text { HADCM2SUL, } \\
\text { HADCM2GHG, } \\
\text { CGCM1, GFDL }\end{array}$ & reduction \\
\hline & & UKMO & expansion \\
\hline & $\mathrm{MC1}$ & $\begin{array}{l}\text { HADCM2SUL, } \\
\text { CGCM1 }\end{array}$ & reduction \\
\hline \multirow[b]{2}{*}{$\begin{array}{c}\text { taiga-tundra and } \\
\text { tundra }\end{array}$} & MAPSS & & reduction \\
\hline & $\mathrm{MC1}$ & $\begin{array}{l}\text { HADCM2SUL, } \\
\text { CHCM1 }\end{array}$ & reduction \\
\hline
\end{tabular}

Table 2 shows that GCM scenarios can generate significant differences in the simulated future response of ecosystems and the same is confirmed by Lenihan et al. (2008a). In contrast to Bachelet et al. (2001), Lenihan et al. (2008a) included in their simulations fire regime as well, and came to different results assuming unsuppressed or suppressed fire (Table 3). Considering the role of fire may be important as Bachelet et al. (2003) predict an increase in total biomass burnt in the $21^{\text {st }}$ century.

Table 3. Simulated changes in vegetation in the U.S. for the period 2070-2099 under different fire regimes (Lenihan et al., 2008a)

\begin{tabular}{|c|l|l|}
\hline Vegetation type & \multicolumn{1}{|c|}{ Fire regime } & \multicolumn{1}{|c|}{ Character of change } \\
\hline \multirow{2}{*}{ temperate conifer forest } & unsuppressed fire & expansion \\
\cline { 2 - 3 } cool mixed forest & suppressed fire & expansion \\
\hline \multirow{2}{*}{ tropical forest } & unsuppressed fire & reduction \\
\cline { 2 - 3 } & suppressed fire & reduction \\
\cline { 2 - 3 } grassland & unsuppressed fire & expansion \\
\hline \multirow{2}{*}{ woodland/savanna } & unsuppressed fire & expansion \\
\cline { 2 - 3 } & suppressed fire & $\begin{array}{l}\text { expansion } \\
\text { reduction, replaced by } \\
\text { woodland }\end{array}$ \\
\cline { 2 - 3 } & unsuppressed fire & expansion \\
\hline & suppressed fire & $\begin{array}{l}\text { reduction, replaced by } \\
\text { forest }\end{array}$ \\
\hline
\end{tabular}




\begin{tabular}{|c|l|l|}
\hline \multirow{2}{*}{ shrubland } & unsuppressed fire & reduction \\
\cline { 2 - 3 } & suppressed fire & $\begin{array}{l}\text { reduction, replaced by } \\
\text { woodland }\end{array}$ \\
\hline \multirow{3}{*}{ subalpine forest } & unsuppressed fire & $\begin{array}{l}\text { reduction, replaced by } \\
\text { temperate forests }\end{array}$ \\
\cline { 2 - 3 } alpine & suppressed fire & reduction \\
\hline & unsuppressed fire & $\begin{array}{l}\text { reduction, replaced by } \\
\text { temperate forests }\end{array}$ \\
\cline { 2 - 3 } & suppressed fire & reduction \\
\hline
\end{tabular}

Under future climate with unsuppressed fire, the most significant change in vegetation distribution is the widespread expansion of woodland/savanna both in the Southeast, where it replaces forest, and in the interior West, where it replaces shrubland (Lenihan et al., 2008a). Besides, a near complete loss of alpine and subalpine forest vegetation can be observed in favour of temperate forest types, a northward shift of forest-type boundaries in the East, and a reduction in the extent of cool mixed forest in the Northeast. Under future climate with suppressed fire, forests in the Southeast remained stable. In the West, there is a widespread conversion of shrubland to woodland and woodland to forest. The woody encroachment also extends into the Central Plains where grassland and shrubland will be converted to woodland.

Although Bachelet et al. (2001) and Lenihan et al. (2008a) included different aspects in their simulations, comparing Table 2 and Table 3, one can see that they came mainly to similar results. The direction of simulated changes is the same in both studies.

Table 4 shows results of simulations conducted by Izaurralde et al. (2005). They used a bit different vegetation types and twelve climate change scenarios, which considered increases in temperature and $\mathrm{CO}_{2}$ concentration. In contrast to Lenihan et al. (2008a), fire disturbance was not taken into account.

In order to have a better overview, Table 5 summarizes the main future trends simulated by the above mentioned three authors regarding several vegetation types. As Bachelet et al. (2001) considered two models and several scenarios, it was necessary to simplify, thus only the most likely changes (predicted by the most scenarios) are displayed in Table 5.

Table 4. Simulated changes in vegetation in the U.S. (Izaurralde et al., 2005)

\begin{tabular}{|l|l|}
\hline \multicolumn{1}{|c|}{ Vegetation type } & \multicolumn{1}{c|}{ Character of change } \\
\hline boreal deciduous forest/woodland & expansion \\
\hline boreal conifer forest/woodland & reduction \\
\hline temperate/boreal mixed forest & reduction \\
\hline temperate conifer forest & expansion \\
\hline temperate deciduous forest & expansion \\
\hline tropical deciduous forest & expansion (new vegetation type) \\
\hline moist savanna & reduction \\
\hline dry savanna & reduction \\
\hline tall grassland & reduction \\
\hline short grassland & reduction \\
\hline xeric woodlands/shrub & expansion \\
\hline
\end{tabular}




\begin{tabular}{|l|l|}
\hline arid shrubland/steppe & expansion or reduction \\
\hline desert & expansion \\
\hline
\end{tabular}

Table 5. Comparison of simulated future changes in vegetation in the U.S. according to different authors $(\uparrow=$ expansion, $\downarrow=$ reduction, $-=$ not mentioned $)$

\begin{tabular}{|c|c|c|c|}
\hline $\begin{array}{c}\text { Vegetation } \\
\text { type }\end{array}$ & $\begin{array}{c}\text { Bachelet et al. } \\
\text { (2001) }\end{array}$ & $\begin{array}{c}\text { Lenihan et al. } \\
\mathbf{( 2 0 0 8 a )}\end{array}$ & $\begin{array}{c}\text { Izaurralde } \\
\text { et al. (2005) }\end{array}$ \\
\hline $\begin{array}{c}\text { boreal } \\
\text { deciduous } \\
\text { forest }\end{array}$ & - & - & $\uparrow$ \\
\hline $\begin{array}{c}\text { boreal conifer } \\
\text { forest }\end{array}$ & $\uparrow$ & - & $\downarrow$ \\
\hline $\begin{array}{c}\text { temperate } \\
\text { deciduous } \\
\text { forest }\end{array}$ & $\uparrow / \downarrow$ & $\uparrow$ & $\uparrow$ \\
\hline $\begin{array}{c}\text { temperate } \\
\text { conifer forest }\end{array}$ & $\uparrow$ & $\downarrow$ & $\uparrow$ \\
\hline $\begin{array}{c}\text { northeast } \\
\text { mixed forest }\end{array}$ & $\downarrow$ & - & $\downarrow$ \\
\hline $\begin{array}{c}\text { southeast } \\
\text { mixed forest }\end{array}$ & $\downarrow$ & $\uparrow$ & - \\
\hline tropical forest & $\uparrow$ & $\uparrow / \downarrow$ & $\downarrow$ \\
\hline savanna & $\uparrow / \downarrow$ & $\downarrow$ & $\uparrow / \downarrow$ \\
\hline shrubland & $\uparrow / \downarrow$ & $\downarrow$ & $\uparrow$ \\
\hline grassland & $\downarrow$ & $\downarrow$ & - \\
\hline desert & $\downarrow$ & & $\downarrow$ \\
\hline tundra / alpine & $\downarrow$ & & $\uparrow$ \\
\hline
\end{tabular}

It can be observed that predicted changes are not always clear. All three authors agree that temperate conifer forests as well as tropical forests are expected to expand, while northeast mixed forest is likely to decrease. Tundra and alpine vegetation is also predicted to lose area, however, trends regarding savanna and shrubland vary.

\section{Alaska}

\section{Expected changes in environmental factors}

According to climate change scenarios and observations, the greatest magnitude of warming will occur at high latitudes $\left(45-65^{\circ} \mathrm{N}\right)$, with the most marked effects within the continental interiors (Hansen \& Lebedeff, 1987; Lashof \& Ahuja, 1990; Houghton et al., 1996; Kattenberg et al., 1996; Serreze et al., 2000; IPCC, 2001; Christensen et al., 2007). In Alaska, a warming trend of $0.75{ }^{\circ} \mathrm{C}$ per decade has been identified for the last three decades of the $20^{\text {th }}$ century over land bordering the Bering Sea (Chapman \& Walsh, 1993; Serreze et al., 2000). Some authors expect an increase of 3-8 ${ }^{\circ} \mathrm{C}$ in air temperature in the Arctic within the next 50 years (Hansen \& Lebedeff, 1987; Maxwell, 1992), while others suggest a rise of $1-2{ }^{\circ} \mathrm{C}$ over 20 years and $4-5{ }^{\circ} \mathrm{C}$ over 100 years 
(BESIS, 1997). Chapin et al. (1995) suggest that regional climatic warming may already be altering species composition of Alaskan arctic tundra. Warming can affect plant community composition, biomass and productivity directly through warmer air and soil temperatures (Kane et al., 1992; Maxwell, 1992) and indirectly through alteration of soil water and nutrient availability. Increased air temperature directly stimulates plant growth and plant species shifts across a range of tundra ecosystems (Arft et al., 1999; Jonasson et al., 1999; Dormann \& Woodin, 2002; van Wijk et al., 2003; Walker et al., 2006), and also stimulates soil warming and nutrient release from soil organic matter (Schuur et al., 2007). However, increased nutrient availability, in particular nitrogen, also increases plant growth and shifts species composition in many well-drained tundra ecosystems (Jonasson et al., 1999; Shaver et al., 2001; Dormann \& Woodin, 2002; van Wijk et al., 2003; Mack et al., 2004; Czóbel et al., 2013; Walker et al., 2006). In addition, warming can cause permafrost (permanently frozen soil) to thaw and thermokarst (ground subsidence) to develop, which can alter the structure of the ecosystem by altering hydrological patterns within a site (Schuur et al., 2007). Nitrogen also may increase in availability as permafrost thaws (Shaver et al., 2001; Mack et al., 2004). The altered moisture regime promotes mesophilic mosses (Camill, 1999) and vascular plants in some areas (Lloyd et al., 2003), while preventing growth of other species (Jorgenson et al., 2001). The indirect effect of changing moisture regime on soil nutrient availability is also likely to affect plant growth and species composition (Schuur et al., 2007). Overall, the net effect of warming on vegetation and ecosystem dynamics is likely to be strongly dependent on moisture status following thaw (Oechel et al., 1994; Camill, 1999). Other authors emphasize an overriding influence of nutrient limitation on tundra production in the Low Arctic and suggest that environmental factors are expected to affect net primary production of the whole ecosystem only if they alter nutrient availability (Jonasson, 1992; Shaver et al., 1992). On the contrary, shoot growth of plants of individual species responds sensitively to changes in light, temperature and nutrients (Chapin \& Shaver, 1985; Shaver et al., 1986, Parsons et al., 1994). The response of the species may, however, cancel out at the ecosystem level due to a redistribution of resources among species in the community (Chapin et al., 1995).

\section{Vegetation changes - compositional shift in tundra}

At high latitudes, even relatively small changes in temperature could have large consequences to boreal and tundra ecosystems (Viereck et al., 1986). Alaska's North Slope is especially vulnerable to climatic change; vegetation changes result there from the interplay of climate, vegetation response and landscape processes (Kittel et al., 2011). Climate-related changes will depend not only on the magnitude and direction of temperature and precipitation shifts, but also on storm and high wind event frequency and intensity. In the High Arctic, under warmer air temperatures and longer growing seasons, areas with sparse vegetation and deep active layers may develop a thicker and more wide-spread layer of moss (Epstein et al., 2004a). Moist non-tussock tundra responds to warming with conversion to wetlands and expanding thaw lakes as the active layer deepens and ground subsides (Kittel et al., 2011).

As for the Low Arctic, upland moist acidic tundra is the most common vegetation association and it is highly sensitive to climate warming (Epstein et al., 2004a). Paleoenvironmental studies support the conclusion that climatic change has the potential to alter current boundaries between moist non-acidic tundra and moist acidic 
tundra, with warming favouring moist acidic tundra (Kaufman et al., 2004). However, it is still unclear how quickly such a conversion could occur. The shift from non-acidic to acidic tundra in the mid-Holocene took on the order of centuries to millennia (Oswald et al., 2003). In their research, Schuur et al. (2007) found that aboveground plant biomass ranged from being dominated by sedges (graminoids, such as Eriophorum vaginatum), to becoming increasingly dominated by deciduous and evergreen shrubs (including Rubus chamaemorus, Vaccinium uliginosum and Betula nana) and mosses across the studied sites as thermokarst became more developed. It means that plant species and functional group shifts among sites are driven by changes occurring at the microsite level, via changes in microclimate that accompanied ground subsidence. Changes in hydrology produced by ground subsidence create a wide range of microenvironments that affect plant species composition and growth as well. Shrubs and moss prefer warm and moist sites, whereas graminoids dominate cold and dry sites.

Chapin et al. (1995) did not consider topographical changes when conducting manipulation experiments in moist tussock tundra in Alaska. Although they found contrasting responses to temperature increase and to nutrient addition by different growth forms, they came to similar results as Schuur et al. (2007) regarding changes in dominance of life forms. Chapin et al. (1995) concluded that some of the manipulations altered nutrient availability, biomass, growth-form composition, net primary production and species richness in less than a decade, indicating that arctic vegetation is sensitive to climatic change. However, short-term responses were poor predictors of longer term changes in community composition. According to their results, nitrogen and phosphorus availability tended to increase in response to elevated temperature, reflecting increased mineralization (cf. Schuur et al., 2007). Nutrient addition increased biomass and production of deciduous shrubs but reduced growth of evergreen shrubs and nonvascular plants. Elevated temperature enhanced shrub production but reduced production of nonvascular plants. At the end of the long-term treatment, deciduous shrubs dominated, and graminoids, evergreen shrubs, and nonvascular plants declined. Species richness was reduced by $30-50 \%$ by temperature and nutrient treatments, due to loss of less abundant species. In summary, resources required for growth (i.e., nutrients and light) appeared to be more critical than temperature in determining plant biomass in tussock tundra.

\section{Shrub expansion}

Increased temperatures have been observed to promote shrub expansion on the North Slope and also elsewhere in Alaska over recent decades (Chapin et al., 1995; Shaver et al., 1998; Sturm et al., 2001b; Tape et al., 2006; Strack et al., 2007; Lawrence \& Swenson, 2011). The fact that moist tussock tundra would give way to moist low shrub tundra (Epstein et al., 2004a; Kittel et al., 2011) is supported by field manipulation experiments as well (Chapin \& Shaver, 1996; Bret-Harte et al., 2001; Hobbie \& Chapin, 1998; Shaver et al., 2001; Jonsdottir et al., 2005). However, in contrast to the study by Schuur et al. (2007), increased shrub abundance in some fertilizer treatments correlated with decreased moss abundance, as canopy closure decreased growth and survival of nonvascular mosses and lichens (Chapin \& Shaver, 1996; Shaver et al., 2001). Arft et al. (1999) again came to different results, concluding that increases in deciduous shrub and graminoid cover together occurred across sites, whereas nonvascular cover decreased. However, initial responses in productivity may not entirely reflect the long- 
term trajectory of species dominance (Hollister et al., 2005). Overall, a warmer and wetter climate would promote peat formation and shrub expansion, in contrast, a warmer and drier climate may foster drier upland tundra landscapes (Kittel et al., 2011). According to Epstein et al. (2004a), the transition between tussock tundra and low shrub tundra appears to be responding most rapidly to climatic warming as this transition correlates more strongly with climate than with other environmental variables, besides, dominant species exhibit gradual changes in abundance and they have demographic properties that allow rapid increases in abundance following climatic shifts. Shrubs can achieve dominance potentially within a decade, whereas spruce trees often require several decades to centuries to achieve dominance within tundra, and Sphagnum moss colonization of non-acidic sites may require centuries to millennia of soil development (Epstein et al., 2004a).

\section{Compositional change in boreal forests}

Global vegetation models predict that boreal forests are particularly sensitive to a biome shift during the $21^{\text {st }}$ century (Beck et al., 2011). In the boreal forest region of Alaska, the average mean annual temperature increased $1.6{ }^{\circ} \mathrm{C}$ from 1949 to 1999 (Stafford et al., 2000). Increased growing season and warmer temperatures over the next century are predicted to generate increases in forest in northern Alaska (Euskirchen et al., 2009; Barrett \& Gray, 2011). However, thermokarsts can collapse boreal forests, to be replaced over time by meadows, bogs and lakes (Osterkamp et al., 2000). Barrett \& Gray (2011) suggest that the boreal region is suspected to be a significant possible source of greenhouse gases as climate warms.

Climatic warming and associated increases in nutrient availability are expected to enhance the probability of white spruce (Picea glauca) surviving on the North Slope (Kittel et al., 2011). Rupp et al. (2000) suggest that the most plausible change from upland tundra in response to climatic warming is to conifer forest due to invasion of white spruce forest, because this is the forest type that most commonly occurs south of the Alaskan arctic tree line (Bliss \& Matveyeva, 1992; Starfield \& Chapin, 1996). The same is confirmed by Brubaker et al. (1983) and by Barrett and Gray (2011) as well. However, the Brooks Range may be an effective barrier to northward migration and expansion of this species (Kaufman et al., 2004; Rupp et al., 2000). Besides, Juday and Solomon (2000) observed significant declines in white spruce growth rates after 1976 when summer air temperatures increased. Thus, drought stress could be a controller of production and survival of these trees. Calef et al. (2005) predict that black spruce (Picea mariana) will remain the dominant vegetation type under all scenarios, potentially expanding most under warming coupled with increasing fire interval.

According to Juday and Solomon (2000), species of deciduous poplar and aspen (Populus spp.) trees appear to be better adapted to warmer and drier summer conditions than white spruce. Simulations by Leemans (1991) and Prentice et al. (1993) predict a gradual elimination of conifer species and an increase in abundance of hardwood species such as oak (Quercus sp.) with winter warming scenarios. The same is confirmed by Potter (2004), who suggests that taiga forests of interior Alaska have changed markedly over the past 50 years of climate warming, and whose projections predict a shift from dominance by evergreen needleleaf trees (taiga) to mixed broadleafneedleleaf tree composition in the future. This is consistent with observations by Roland (1999) as well, who found increased colonization by paper birch (Betula papyrifera) 
seedlings with climate warming in forest plots in Alaska. Besides, following fire, early successional broad-leaved deciduous shrubs and trees (Larsen, 1965; Viereck, 1973; Payette \& Gagnon, 1985) replace white spruce forests. Calef et al. (2005) suggest that deciduous forests will expand their range the most in the case of decreasing fire interval, warming or increasing precipitation.

Overall, similar changes are predicted by Beck et al. (2011), who suggest that evergreen forests will expand into current tundra while being replaced by grasslands or temperate forest at the biome's southern edge throughout interior Alaska, due to drought-induced productivity declines. According to simulations by Rupp et al. (2000), tundra could be converted to forest within 200 years, however, partial barriers may slow this conversion by 300-400 years. Simulations by Bachelet et al. (2005) show that 75$90 \%$ of the area simulated as tundra in 1922 will be replaced by boreal and temperate forest by the end of the 21 st century. Ultimately, tree dispersal rates, habitat availability, the rate of future climate change and how it changes disturbance regimes, are expected to determine where the boreal biome will undergo a gradual geographic range shift, and where a more rapid decline (Beck et al., 2011). Calef et al. (2005) concluded that tundra can be replaced by forest under warming but is expected to expand under precipitation increase.

The successional switch of broad-leaved deciduous forest to white spruce forest can be accelerated by both heavy moose browsing pressure and extremely cold climate (Kielland et al., 1997). 1982). Grasslands occur under dry conditions in the boreal forest zone (Edwards \& Armbruster, 1989). Under cold climatic conditions dry grassland may switch to upland tundra (Starfield \& Chapin, 1996; Chapin \& Starfield, 1997), however, a switch from upland tundra to dry grassland may also occur under extremely dry conditions. Dry grassland will switch to a broad-leaved deciduous forest type under not too dry climate conditions if a seed source exists (Rupp et al., 2000).

\section{Role of natural disturbances}

Natural disturbances further complicate direct impacts from temperature increase (Barrett \& Gray, 2011). Barrett \& Gray (2011) suggest that not only direct climateplant interactions may cause range shifts, but other disturbance events such as outbreaks of spruce beetles. Besides, spatial features (e.g., topographic barriers) and processes, including disturbance propagation and seed dispersal, largely control the pattern and rate of short-term transient changes (Rupp et al., 2000). Under future climate change scenarios, fire emissions and the area burned are expected to increase (Bachelet et al., 2005) as longer and warmer summers can increase fire frequency, which in turn affects permafrost and alters rates of dispersal and growth for boreal species (Rupp et al., 2002; Wirth et al., 2008). According to Rupp et al. (2000), topographic barriers have little influence on fire size in low-flammability vegetation types (such as upland tundra and broad-leaved deciduous forest), but reduce the average fire size and increase the number of fires in highly flammable vegetation (e.g. dry grassland). Bachelet et al. (2005) suggest that by the end of the $21^{\text {st }}$ century Alaska may become a net carbon source. The role of fire is underlined by the fact that changes in fire severity can have more effect on post-fire community composition than environmental factors (moisture and $\mathrm{pH}$ ) do (Bernhardt et al., 2011). 


\section{California}

\section{Changes in environmental conditions}

California is one of the most climatically and biologically diverse areas in the world (Lenihan et al., 2003). According to predictions, California may experience substantially warmer and wetter winters, somewhat warmer summers, and an enhanced El Niño Southern Oscillation during the $21^{\text {th }}$ century (Field et al., 1999; Gutowski et al., 2000). However, Urban et al. (2000) suggest that although current general circulation models all predict warmer temperatures for California under enhanced $\mathrm{CO}_{2}$ scenarios (VEMAP, 1995), the models do not agree on the direction of change in precipitation. These projected changes are proven by trends in the recent past as well. Southern California's climate warmed at the surface, the precipitation variability increased, and the amount of snow decreased between 1977 and 2006-2007 (Kelly \& Goulden, 2008).

\section{Vegetation changes}

According to simulations by Diffenbaugh et al. (2003), vegetation in the western United States is sensitive to changes in atmospheric $\mathrm{CO}_{2}$ concentrations, with woody biome types replacing less woody types throughout the domain. It is also sensitive to climatic effects, particularly at high elevations, due to both warming throughout the domain and decreased precipitation in key mountain regions such as the Sierra Nevada of California and the Cascade and Blue Mountains of Oregon.

A change in climate is expected to shift plant distribution as species expand in newly favourable areas and decline in increasingly hostile locations (Kelly \& Goulden, 2008). According to a study by Kelly and Goulden (2008) in Southern California's Santa Rosa Mountains, the average elevation of the dominant plant species rose approximately 65 $\mathrm{m}$ between 1977 and 2006-2007, which appears to be a consequence of changes in regional climate. On the contrary, Crimmins et al. (2011) suggest that climate changes in California have also resulted in a significant downward shift in species' optimum elevations. Although this downhill shift is counter to what would be expected given $20^{\text {th }}$-century warming, it can be explained by species' niche tracking of regional changes in climatic water balance rather than temperature. Similar downhill shifts can be expected to occur where future climate change scenarios project increases in water availability that outpace evaporative demand. However, Lutz et al. (2010) predict declining water availability and increasing climatic water deficit for Yosemite National Park, California, resulting in accelerating changes in forest structure and composition in the future.

In Californian tidal marshes, salinity has increased because of water diversion and sea level has risen as well since 1975, which lead to the increased cover of the most salttolerant plant species (Sarcocornia pacifica, Pacific swampfire), whereas Schoenoplectus californicus (California bulrush), the least salt-tolerant plant species, decreased in cover (Watson \& Byrne, 2012). Besides, accelerated sea level rise resulted in the large-scale replacement of Distichlis spicata (seashore saltgrass) predominantly by Schoenoplectus americanus (chairmaker's bulrush) (Watson \& Byrne, 2012).

Lenihan et al. (2003) simulated future vegetation distribution for the period 20702099 using two models, the Hadley Climate Center HADCM2 model (HAD) and the National Center for Atmospheric Research Parallel Climate Model (PCM) (Table 6, 7 and 8$)$. 
Table 6. Simulated changes in vegetation for 2070-2099 in California (Lenihan et al., 2003)

\begin{tabular}{|c|c|c|}
\hline Vegetation classes & HAD & PCM \\
\hline alpine / subalpine forest & $\begin{array}{l}\text { partly replaced by evergreen } \\
\text { conifer forest }\end{array}$ & $\begin{array}{l}\text { partly replaced by } \\
\text { shrubland }\end{array}$ \\
\hline evergreen conifer forest & $\begin{array}{l}\text { partly replaced by mixed } \\
\text { evergreen forest; net } \\
\text { increase }\end{array}$ & $\begin{array}{l}\text { partly replaced by mixed } \\
\text { evergreen woodland; partly } \\
\text { replaced by mixed } \\
\text { evergreen forest; net loss }\end{array}$ \\
\hline mixed evergreen forest & $\begin{array}{l}\text { expansion; partly replaced } \\
\text { by evergreen conifer forest }\end{array}$ & $\begin{array}{l}\text { partly replaced by mixed } \\
\text { evergreen woodland }\end{array}$ \\
\hline $\begin{array}{l}\text { mixed evergreen } \\
\text { woodland }\end{array}$ & $\begin{array}{l}\text { partly replaced by mixed } \\
\text { evergreen forest; partly } \\
\text { replaced by evergreen } \\
\text { conifer forest }\end{array}$ & $\begin{array}{l}\text { partly replaced by } \\
\text { grassland; net decline }\end{array}$ \\
\hline grassland & $\begin{array}{l}\text { expansion; partly replaced } \\
\text { by mixed evergreen forest }\end{array}$ & \\
\hline shrubland & $\begin{array}{l}\text { partly replaced by mixed } \\
\text { evergreen forest; partly } \\
\text { replaced by evergreen } \\
\text { conifer forest }\end{array}$ & $\begin{array}{l}\text { partly replaced by } \\
\text { grassland; net decline }\end{array}$ \\
\hline desert & partly replaced by grassland & \\
\hline
\end{tabular}

Table 7. Regional examples for vegetation changes according to HAD in California (Lenihan et al., 2003)

\begin{tabular}{|l|l|}
\hline \multicolumn{1}{|c|}{ Replaced } & \multicolumn{1}{c|}{ Replaced by } \\
\hline Douglas-fir-white fir forest & Douglas-fir-tan oak forest \\
\hline white fir-ponderosa pine forest & ponderosa pine-black oak forest \\
\hline blue oak woodlands & tan oak-madrone-canyon live oak forest \\
\hline chaparral & $\begin{array}{l}\text { tan oak-madrone-canyon live oak forest; } \\
\text { coast live oak-madrone; canyon live oak- } \\
\text { Coulter pine; redwood and closed-cone } \\
\text { pines }\end{array}$ \\
\hline perennial grassland & tan oak-madrone-canyon live oak forest \\
\hline live oak woodlands & $\begin{array}{l}\text { coast live oak-madrone; canyon live oak- } \\
\text { Coulter pine }\end{array}$ \\
\hline northern juniper woodland & ponderosa pine-Jeffrey pine forest \\
\hline sagebrush scrub & ponderosa pine-Jeffrey pine forest \\
\hline canyon live oak-madrone forest & redwood and closed-cone pines \\
\hline subalpine parks and meadow & red fir and lodgepole pine \\
\hline
\end{tabular}


Table 8. Regional examples for vegetation changes according to PCM in California (Lenihan et al., 2003)

\begin{tabular}{|l|l|}
\hline \multicolumn{1}{|c|}{ Replaced } & \multicolumn{1}{c|}{ Replaced by } \\
\hline northern juniper woodland & grassland \\
\hline sagebrush scrub & grassland \\
\hline oak woodland communities & grassland communities \\
\hline chaparral & grassland communities \\
\hline Douglas-fir-tan oak forest & northern oak woodland \\
\hline Douglas-fir-white fir forest & northern oak woodland \\
\hline alpine meadow communities & whitebark pine krummholtz \\
\hline
\end{tabular}

In summary, according to Lenihan et al. (2003), the HAD scenario predicts a warmer and wetter climate resulting in the expansion of forests and in a net increase in evergreen conifer forest. However, the simulated life-form composition is expected to change from needleleaf dominance to mixed needleleaf-broadleaf in the northern half of the state. In addition to widespread advancement of forests, another prominent feature of the response of vegetation distribution under the HAD scenario is the advancement of grassland. Under the drier and cooler PCM scenario, the expansion of grassland is predicted along with a net decline in evergreen conifer forest, mixed evergreen woodland and shrubland.

Using other climate scenarios, Lenihan et al. (2008b) came to similar results. Predicted changes include significant declines in the extent of alpine/subalpine forest due to longer and warmer growing seasons; the replacement of evergreen conifer forest by mixed evergreen forest with increases in temperature, or by woodland, shrubland or grassland with increases in fire; and an increase in the extent of mixed evergreen forest. Furthermore, a decline in mixed evergreen woodland and shrubland as well as the expansion of grassland are expected. These results are confirmed by Rehfeldt et al. (2006) as well.

In contrast to the previous studies, Urban et al. (2000) suggest that besides temperature and precipitation, supply and demand components of the water balance should be considered as well. Although temperature and precipitation can predict the location of the mixed conifer zone, several species can co-occur within this zone, as defined by the spatial scaling of microtopography and soils. Under climatic change, species might move around within this zone, more mesic species being displaced to deeper soils or more northerly exposures, while more xeric species to shallower soils or more southerly exposures.

Zavaleta et al. (2003) showed that relative dominance of functional groups may shift in grasslands due to increases in temperature, precipitation, $\mathrm{CO}_{2}$ concentration and $\mathrm{N}$ deposition. They found that grassland diversity and composition were sensitive to all four of the individual global changes, supporting the fact that grasslands containing fastgrowing or short-lived species are especially responsive to climate change (Grime et al., 2000). According to their experiments, the largest change in relative functional group abundance (expansion of forbs) occurs under the combination of elevated $\mathrm{CO}_{2}+$ warming + precipitation (Zavaleta et al., 2003), which will likely affect much of California in the future (Giorgi et al., 1994). Thus, forbs - which include most of the remaining native species in Californian grasslands (Hickman, 1993) - could be the group of species in grasslands most vulnerable to environmental changes, including 
climate and atmospheric changes. Zavaleta et al. (2003) also suggest that individual species are more sensitive to temporal variation and extremes than to multiyear, mean changes in resource availability and environmental conditions, which is consistent with predictions by IPCC (2001).

\section{Southwestern USA}

\section{Changes in environmental conditions}

Climate models predict a warmer and drier climate throughout the southwestern U.S. in the $21^{\text {st }}$ century (Seager et al., 2007; Solomon et al., 2009). Warmer temperatures and increasing frequency of droughts should cause major shifts in plant community composition and structure (Allen, 2007; Williams \& Jackson, 2007) in this region via differences in mortality and drought adaptations among woody species.

\section{Susceptibility for invasion}

Plant population dynamics in arid and semiarid lands is highly dependent on water availability, thus, under future climate change these systems are expected to be drastically affected by changes in precipitation and temperature (Kerkhoff et al., 2004; Suazo et al., 2012). Changing precipitation regimes (such as changes in the amount and timing of precipitation and increases in large rainfall events) may enhance the susceptibility of habitats to invasion by non-native plant species (Weltzin et al., 2003; Bradley, 2009). Besides, this kind of susceptibility may be increased by increases in nutrient availability (Davis et al., 2000) and soil disturbance (Burke \& Grime, 1996; Huston, 2004) as well since the spread and establishment of non-native plant species can be facilitated by the physical condition and resource availability of the invaded habitat (Davis et al., 2000; Burke \& Grime, 1996). Invasive species compete with natives for water and soil nutrients (Brooks, 2000), and non-native species are often more efficient than natives at capturing these resources and utilize them for seed production (Monaco et al., 2003; Huxman et al., 2008; DeFalco et al., 2003). In the Mojave Desert, an experiment by Suazo et al. (2012) showed that invasion success increased with availability of unused water, at least for the grass Schismus spp. (Mediterranean grass). Schismus seemed to have the greatest invasive potential at the studied sites, as it positively responded to water availability and soil disturbance. Others have also observed similar responses by Schismus to increased levels of water availability (James et al., 2006; Gutierrez \& Whitford, 1987; Pake \& Venable 1995). Beside water availability, soil $\mathrm{N}$ has been suggested to be a co-limiting factor for nonnative plant establishment in the Mojave Desert (Brooks, 2003; Rao \& Allen, 2010; James et al., 2006). Although it is difficult to predict future patterns of invasibility, an increase in water availability and disturbance is likely to enhance invasibility in this ecosystem (Weltzin et al., 2003; Bradley et al., 2009; Bradley, 2009; Bradley, 2010).

\section{Drought-induced mortality}

Drought-induced woody plant mortality has increased globally recently and has been associated with increasing temperatures (Breshears et al., 2005; Allen et al., 2009b; van Mantgem et al., 2009; Adam et al, 2009). Accelerated plant mortality over the next century, induced by climate warming and drought (Hansen et al., 2006; IPCC, 2007; Allen et al., 2009a; Kintisch, 2009), is predicted to be especially pronounced in 
mountain forests of the southwestern U.S. (Rehfeldt et al., 2006; Seager et al., 2007). Adams et al. (2009) showed that experimentally induced warmer temperatures shortened the time to drought-induced mortality in Pinus edulis (pinyon pine), and projected increases in drought frequency due to changes in precipitation and increases in stress from biotic agents (e.g. bark beetles) could further exacerbate mortality. Shifts in vegetation distribution are expected to be most rapid and extreme at ecotones, the boundaries between ecosystems, particularly those in semiarid landscapes (Allen \& Breshears, 1998). According to Allen and Breshears (1998), the most rapid landscapescale shift of a woody ecotone ever documented occurred in northern New Mexico in the 1950s, where the ecotone between semiarid ponderosa pine (Pinus ponderosa) forest and pinon-juniper (Pinus edulis, Juniperus monosperma) woodland shifted extensively ( $2 \mathrm{~km}$ or more) and rapidly (in less than 5 years) through mortality of ponderosa pines in response to a severe drought. This shift has persisted for 50 years. Forest patches within the shift zone became much more fragmented, and soil erosion greatly accelerated.

The southwestern U.S., and Arizona in particular, experienced near record warm temperatures and drought during the spring and summer of 2002 (Waple \& Lawrimore, 2003; Andreadis et al., 2005; Weiss et al., 2009), and plants were under severe water stress by the fall of 2002 (Simonin et al., 2006; Gaylord et al., 2007; Breshears et al., 2009). Studying an ecotone between ponderosa pine-dominated forests and pinyonjuniper-dominated woodlands in Arizona during the 2002 drought, Koepke et al. (2010) found little difference in mortality among soil parent materials for individual species or groups of trees and shrubs. They observed greater canopy dieback for shrubs than trees; mortality, however, did not differ between groups. Juniper, the dominant tree with the lowest elevational range, had the lowest mortality of all tree species. In contrast, canopy dieback during severe drought appeared to be a survival mechanism for juniper and to a lesser extent for pinyon pine, but not for ponderosa pine. As a consequence, overall tree cover will be reduced as the community shifts from a mixture of species to more monotypic stand of junipers due to high pine mortality. In addition, surviving junipers and shrubs will likely have diminished leaf area due to canopy dieback. The same is confirmed by Allen and Breshears (1998) and by Müller et al. (2005) as well, who observed higher mortality among reproductively mature trees and survival of smaller pinyons. As approximately 1000 species are associated with pinyon pine, the shift in the structure of these woodlands is expected to have large-scale community consequences.

\section{Shifts in ecosystem types}

Ecotones between oak (Quercus sp.) woodlands and semi-desert grasslands of the southwestern United States and northwestern Mexico have been relatively stable over the past several centuries (Weltzin \& McPherson, 2000b). However, predicted changes in regional precipitation patterns and soil moisture caused by anthropogenic trace gas emissions have the potential to alter interactions between woody plants and grasses with potential ramifications for their relative abundance and distribution. According to a field experiment conducted by Weltzin and McPherson (2000b) in Arizona, Quercus emoryi (Emory oak) recruitment and subsequent abundance and distribution would more likely be affected by changes in summer precipitation than changes in winter precipitation. Thus, increases in summer precipitation may facilitate downslope shifts in the woodland-grassland ecotone. 
As the above examples also show, temporal or spatial shifts in ecosystem types at biome transition zones are often characterized by changes in the dominant species or life form (Gosz \& Sharpe, 1989). In New Mexico, large-scale shifts could be observed in dominance from grasses to shrubs over the past 50-100 years (Buffington \& Herbel, 1965; Peters et al., 2012). According to a biogeographic modelling analysis, an increase in grasslands and decreases in woody vegetation are expected for parts of the southwestern US (Neilson \& Drapek, 1998). Studying transitions between Chihuahuan desert and shortgrass steppe biomes, Peters (2002) also predicted shifts in dominance following directional changes in climate due to modifications in the availability of soil water. In his model, the Chihuahuan desert grass, Bouteloua eriopoda (black grama) dominated both sandy loam soil and loamy sand soil following a change in climate that increased summer precipitation. However, increases in winter precipitation predicted by alternative climate scenarios presumably would favour shrubs (Larrea tridentata, creosotebush) and grasses that respond to cool temperatures, such as Bouteloua gracilis (blue grama).

The importance of water availability is emphasized by Snyder \& Tartowski (2006) as well, who suggest that oscillations between rainfall pulses and intervening dry periods can potentially shift the biological dominance of ecosystems. According to paleoecological records, vegetation in the Northern Chihuahuan Desert has shifted between shrublands in more arid periods, grasslands under more mesic conditions and woodlands during the wettest periods during the past 20,000 years (Van Devender, 1995; Monger, 2003). Wetter winters and drier summers likely facilitated the grass to shrub conversion during the last century (Gao \& Reynolds, 2003). Increased shrub cover can be associated with both greater aridity and increased winter precipitation as shrubs have relative advantage over grasses due to their ability to access deeper soil moisture (Snyder \& Tartowski, 2006). The importance of winter precipitation for woody shrubs is supported by an analysis showing greater woody plant abundance in sites with lower mean annual precipitation and a greater proportion of winter rainfall (Paruelo \& Lauenroth, 1996). It is the amount and seasonality of precipitation that varies at the scale of decades that may determine which of the two functional plant types predominate. Whereas, annual or within-season variation in precipitation influences the relative productivity of the two functional types (Snyder \& Tartowski, 2006). Peters et al. (2002) suggest that multiple wet years are needed to initiate a sequence of grass establishment and survival processes that can maintain upland grasslands.

Atmospheric $\mathrm{CO}_{2}$ enrichment may alter not only the composition but even the structure of grassland vegetation (Polley et al., 2012). According to an experiment conducted by Polley et al. (2012) in tallgrass prairie assemblages in Texas, $\mathrm{CO}_{2}$ enrichment would increase the grass contribution to community production, and favour tall-grasses over mid-grasses. The observed increase in Sorghastrum nutans (yellow indiangrass) was accompanied by an offsetting decline in production of the mid-grass Bouteloua curtipendula (sideoats grama).

Due to global climate change, stream flow regimes are also being altered (Stromberg et al., 2010). In the American Southwest, increasing aridity is predicted to cause declines in stream base flows and water tables, whereas another potential outcome of climate change is increased flood intensity. These changes may affect vegetation, e.g. increased stream intermittency would cause the floodplain plant community to shift from hydric pioneer trees and shrubs (Populus spp., Salix spp., Baccharis spp.) towards 
mesic species (Tamarix spp.) (Stromberg et al., 2010). This shift in functional type would produce changes in vegetation structure, with reduced canopy cover and shorter canopies at drier sites. Among herbaceous species, annuals would increase while perennials would decrease. If flood intensities increased, there would be shifts towards younger tree age, expansion of xeric pioneer shrubs and replacement of herbaceous perennials by annuals. Increased flood intensity would have positive feedback on disturbance processes, by shifting plant communities towards species with less ability to stabilize sediments.

\section{Eastern USA}

\section{Changes in vegetation distribution}

The change in the equilibrium distribution of natural vegetation over eastern North America over the next 200 to 500 years could be larger than the overall change during the past 7000 to 10000 years and equivalent to the change that took place over the 10003000 -year period of the most rapid deglaciation (Overpeck et al., 1991). Some plant ranges and abundance maxima could shift as much as 500 to $1000 \mathrm{~km}$ during the next 200 to 500 years, and such changes would have dramatic impacts on natural ecosystems. Lassiter et al. (2000) predict a considerable northward shift of both northern and southern boundaries of the biomes in the mid-Atlantic region.

Annual temperature in New England is projected to increase by $2.2-3.3{ }^{\circ} \mathrm{C}$ by $2041-$ 2070 and by $3.0-5.2{ }^{\circ} \mathrm{C}$ by $2071-2099$ with corresponding increases in precipitation of 4.7-9.5\% and 6.4-11.4\%, respectively (Tang \& Beckage, 2010). According to simulations conducted by Tang and Beckage (2010), regional warming will result in the loss of $71-100 \%$ of boreal conifer forest in New England by the late $21^{\text {st }}$ century. The range of mixed oak-hickory forests will shift northward by 1.0-2.1 latitudinal degrees (c. $100-200 \mathrm{~km}$ ) and will increase in area by $149-431 \%$ by the end of the $21^{\text {st }}$ century. Northern deciduous hardwoods are expected to decrease in area by $26 \%$ and move upslope by $76 \mathrm{~m}$ on average. These shifts coincide with an approximate $556 \mathrm{~m}$ upslope retreat of the boreal conifer forest by 2071-2099. However, rising atmospheric $\mathrm{CO}_{2}$ concentrations are expected to reduce the losses of boreal conifer forest from expected losses based on climatic change alone. These predictions are in line with recent trends. Beckage et al. (2008) found a 19\% increase in dominance of northern hardwoods between 1964 and 2004 in the northern hardwood-boreal forest ecotone in the Green Mountains, Vermont, and observed a 91- to 119-m upslope shift in the upper limits of this ecotone. Pucko et al. (2011) found evidence that species elevational distributions and community compositions have shifted in response to a $0.49{ }^{\circ} \mathrm{C}$ per decade warming in Vermont. These species responses were complex and largely individualistic at some elevations, while at other elevations species in a given community tended to respond similarly. As for the alpine zone in New York State, Robinson et al. (2010) observed that vegetation composition changed significantly between 1984 and 2007, with an overall decrease in bryophytes/lichens and an increase in vascular plants, indicating that vascular plants were replacing bryophytes, particularly in areas not disturbed. Ibanez et al. (2007) suggest that communities found at higher elevations are in danger of regional extinction if their habitats disappear given the current climatic trends.

Due to rapid global warming, displacement of individual species is predicted as well, such as that of Pinus taeda (loblolly pine), which may shift over $400 \mathrm{~km}$ northward with 
only a narrow region of overlap between the current and projected future range limits (Dyer, 1994). However, potential migration rates may fall short by at least an order of magnitude of that necessary to track projected range shifts. Iverson et al. (2004) also confirmed that there can be a serious lag between the potential movement of suitable habitat and the potential for the species to migrate into the new habitat. According to their results, the proportion of new habitat that might be colonized within a century is low $(<15 \%)$ for all studied species, such as Diospyros virginiana (persimmon), Liquidambar styraciflua (sweetgum), Oxydendrum arboreum (sourwood), Pinus taeda (loblolly pine) and Quercus falcata var. falcata (southern red oak).

\section{Coastal ecosystems}

Although increases in precipitation are predicted for New England (Tang \& Beckage, 2010), climate change may result in increased drought as well. Drought is a primary cause of mortality for island shrub and tree species (Ehrenfeld, 1990). Besides, coastal plant communities are expected to be the first to be affected by the projected increase in sea level resulting from global warming (Ehrenfeld, 1990). The current relative sealevel rise is quoted as $1.5-2 \mathrm{~mm} /$ year along the eastern shore of Virginia (Hayden et al., 1991) and it will affect swale vegetation more than dune vegetation (Shao et al., 1995).

On the barrier islands of the eastern Atlantic Coast of the USA, shrub (Myrica cerifera, wax myrtle) thickets are a major vegetation type (Shao et al., 1995). According to simulations, Shao et al. (1995) found that transpiration patterns of shrub thickets are sensitive to environmental changes including climatic change and sea-level rise. Variations in transpiration with environmental changes are physiological readjustments to the changing environments, which may result in ecological readjustment, such as distributional shifts. Results show that air temperature is less important than humidity in determining shrub thicket distributions on barrier islands, and changes in precipitation patterns are more significant than changes in quantity. Furthermore, soil water, which may rise due to sea-level rise (Ehrenfeld, 1990), is a limiting factor to the transpiration of shrub thickets and thus it plays an important role in determining the distribution of this vegetation type. As a consequence, changes in successional processes and distribution patterns of shrub thickets are sensitive indicators of climatic changes.

\section{Effects of drought}

Not only on barrier islands, but in many other ecosystems as well, drought acts as a disturbance that may initiate large-scale changes in community structure and composition (Tilman \& El Haddi, 1992; Allen \& Breshears, 1998; Condit, 1998; Scheffer et al., 2001; Delissio \& Primack, 2003, Malatinszky et al., 2013a, 2013b). Droughts generally result in decreased productivity, diversity and establishment, increased rates of mortality and altered nutrient cycling in the community (Bollinger et al., 1990; Tilman \& El Haddi, 1992; Condit et al., 1995; Sternberg et al., 1999; Penksza et al., 2009, 2011, 2013; Szentes et al., 2010, 2011a, 2011b; Delissio \& Primack, 2003; O'Neill et al., 2003; Hanson \& Weltzin, 2000). One mechanism by which communities change with disturbances such as drought is through changes in the rate of species turnover (Yurkonis \& Meiners, 2006) since drought can open a temporal colonization window where new species enter the neighborhood (Grime et al., 1994; Davis \& Pelsor, 2001; Bartha et al., 2003, 2009, 2013). 
According to the results of a field study focusing on a 2-month drought event within an early successional forest system in New Jersey (Yurkonis \& Meiners, 2006), drought had little long-term effect on neighbourhood structure (species richness and cover) and generated only subtle changes in neighbourhood composition. Ruderal (annual and biennial) species were more likely to change in cover and frequency due to their limited storage of nutrients and shallow root systems than the more stress tolerant perennial and woody species. Following drought, native and exotic ruderal species tended to increase in cover and frequency across the site. However, population dynamics appeared to be unpredictable and generally driven by stochastic species turnover among fields, not by large-scale shifts in species abundance. Thus, stochastic fine-scale processes can generate predictable coarse-scale dynamics within a disturbed system.

Schultheis et al. (2010) suggest that the projected increase in evapotranspiration coupled with atmospheric nitrogen deposition may lead to the drying up of bogs in the Southern Appalachian Mountains, which can lead to the system becoming a carbon source rather than a sink and to local extinction of many bog species allowing alternative ecosystems to replace the bogs.

\section{Woody encroachment}

It has been observed that abandoned crop- and pasturelands across the eastern part of North America transition from annual and perennial herbs and grasses to various states of woody dominance (Clements, 1916; Oosting, 1942; Keever, 1950; Bazzaz, 1968; Meiners et al., 2002). However, the time required for woody species to achieve dominance varies on the order of decades (Abel, 1941; Bard, 1952; Bazzaz, 1968), e.g. in the Northeast USA, fields can persist as herbaceous assemblages for more than fifty years (Mellinger \& McNaughton, 1975), whereas fields in the Southeast typically transition to closed pine stands in less than a decade (Oosting, 1942; Keever, 1950). Wright and Fridley (2010) documented a clear latitudinal pattern, where the time after field abandonment required to reach certain percent of woody cover increased severalfold from the southern to the northern part of the studied area. This latitudinal pattern was associated with climatic variation, variation in soil fertility, which is generally higher in the soils of the Northeast (von Englen, 1914), and differences in the species pools of both herbaceous and woody pioneer species between regions. According to Wright and Fridley (2010), fields of the Northeast may favour herbaceous persistence due to more fertile soils, cooler temperatures and early successional species pools. Fridley and Wright (2012) concluded that early successional ecosystems may be less sensitive to broad-scale climatic trends because they are driven by interactions between species that are only indirectly related to temperature and rainfall. According to their results, seedlings of southern woody pioneer species are better able to quickly establish in fields after abandonment, regardless of climate regime. Sites of lower soil fertility also exhibited faster rates of seedling growth. This shows that climate plays a relatively minor role in community dynamics at the onset of secondary succession, and that species identity (growth rate) and site edaphic conditions are a stronger determinant of the rate at which ecosystems develop to a woody-dominated state. 


\section{Estuarine ecosystems}

It is known that plant species composition shifts predictably along estuarine salinity gradients, with salt-tolerant halophytic plants dominating salt marshes and nonhalophytic wetland plants dominating tidal freshwater habitats (Simpson et al., 1983; Odum \& Hoover, 1988; Mitsch \& Gosselink, 2000). Studying tidal marsh plant communities in Rhode Island, Crain et al. (2004) found that freshwater marsh plants, when transplanted to salt marshes, did poorly and generally died. In contrast, saltmarsh plants, when transplanted to freshwater marshes, thrived in the absence of neighbours, but when neighbours were present, they were strongly suppressed. This means that biotic interactions also play a key role in driving plant distribution patterns along estuarine salinity gradients.

Charles and Dukes (2009) suggest that salt marsh communities may be resilient to modest warming and large changes in precipitation. If production increases under climate change, marshes will have a greater ability to keep pace with sea-level rise, although an increase in decomposition could offset this. As long as marshes are not inundated by flooding due to sea-level rise, they may be able to increase their carbon storage capability due to increases in aboveground biomass and stem heights under future climate conditions.

\section{Southeastern USA}

\section{Changes in environmental conditions}

Future climates in the southeastern United States are predicted to become warmer, with mean annual total precipitation declining up to $30 \%$ (Hengeveld, 2000). At the same time, heavy rainfall events are predicted to increase in the middle United States (Woodhouse \& Overpeck, 1998; Easterling et al., 2000), which could cause sudden flooding in wetlands.

\section{Mangrove and hardwood hammock ecosystems}

In the Greater Everglades region of southern Florida, mangrove ecosystems and hardwood hammock ecosystems occupy overlapping geographical ranges (Odum et al., 1982; Odum \& McIvor, 1990; Sklar \& van der Valk, 2003). These two vegetation types are frequently in competition, although they are typically not interspersed but there are sharp boundaries between their uniform patches (Teh et al., 2008). Hardwood hammocks generally occupy areas of higher elevation, where salinities are low, while mangroves can tolerate higher salinity levels but also have the ability to grow in freshwater (Sternberg \& Swart, 1987; Odum \& Mclvor, 1990). There exists an equilibrium state at which both vegetation types are present, where the salinity of the vadose layer is at an intermediate level of lethality for freshwater hammock species (Sternberg et al., 2007).

Teh et al. (2008) suggest that because of climate change, sea level rise and storm surges are potential perturbations which may cause the vegetation to shift from hardwood hammocks to mangroves as an increase in salinities of the vadose zone induced by these events might eradicate the salinity-intolerant hardwood hammocks at higher elevations and promote landward migration of mangroves. This is confirmed by Doyle et al. (2003) as well, who observed that the occurrence of hurricanes is 
responsible for the composition of mangrove communities across southern Florida today. Besides, it is documented that mangroves have migrated approximately $3.3 \mathrm{~km}$ inland in the southern Everglades during the past half-century, largely at the expense of freshwater marshes and swamp forest (Gaiser et al., 2006). In their model, Teh et al. (2008) considered high salinity developed during the dry season to be the major determinant of vegetation distribution in Florida, and found that under stable environmental conditions, hardwood hammocks occupied the higher elevation cells, while mangroves occupied the lower ones, just like in nature. In the event of a light surge, hardwood hammocks were able to restore the salinity to low levels in a short time period by decreasing their transpiration rates. However, a medium surge event that saturated the vadose zone at $15 \mathrm{ppt}$ caused the mangroves to invade the cells at higher elevation, and a heavy surge caused them to take over the entire study domain after 50 years. The rate of domination by mangroves in the high elevation cells after a storm surge was found to depend on the thickness or depth of the vadose zone. This modelling study also proves that changes in vegetation may occur not only through gradual changes in the environment, but also by a sudden disturbance event.

Simulations by Sternberg et al. (2007) show that the primary effect of changes in precipitation (caused by climate change) and ground water salinity (brought about by sea water intrusion) will be on the inland hammock frequency and not on the mangrove/hammock boundary. Decrease in precipitation relative to the average yearly precipitation of about $1,000 \mathrm{~mm}$ in South Florida will cause a significant decrease in hammock frequencies. The mangrove/hammock boundary, however, will only move inland to higher elevation when precipitation is drastically reduced. Likewise, increases in the salinity of the groundwater underlying the vadose zone will have a strong impact on the inland hammock frequency, but little impact on the mangrove/hammock boundary.

\section{Changes in hydrological properties}

Hydrological properties are considered to be a driving force in structuring wetland communities (Gunderson \& Loftus, 1993; Mitsch \& Gosselink, 2007); particularly, duration and depth of flooding are the major factors controlling plant distribution (Gunderson, 1994). Numerous studies have shown a relationship between Everglades hydropatterns and the plant communities found there (Armentano et al., 2006; Davis et al., 1994; Gunderson, 1994; Ross et al., 2003; Zweig \& Kitchens, 2008; Zweig \& Kitchens, 2009). Gunderson (1994) suggested that the hydrology of the Everglades is affected at three different temporal scales with the slow time scale being change in sea level, the intermediate scale being the return period of droughts and floods and the fast scale being the annual hydrologic regime which is dominated by seasonal variation in rainfall. Some authors have shown that vegetation change in response to hydrologic alteration can be relatively rapid (i.e. a few years) (Armentano et al., 2006; Zweig \& Kitchens, 2008), while others argue that there can be a considerable time lag (Givnish et al., 2008; Ross et al., 2003). Nevertheless, changes in the hydrology due to climate change can potentially have profound impacts on the distribution and prevalence of vegetation communities (Jason Todd et al., 2010).

In coastal ecosystems, regeneration may be dictated by disturbances related to hurricanes, water fluctuation, and/or saltwater intrusion (Platt \& Connell, 2003; Middleton, 2009a, b, c, d). These disturbances may increase in the future with climate 
change, particularly because of increased hurricane activity, sea-level rise (Michener et al., 1997), or declining freshwater input (Middleton, 1999). Other authors also confirm that water depth and salinity changes can greatly alter seed germination and seedling growth of species (Middleton, 1999, 2009a, d; Howard \& Mendelssohn, 2000; Brock et al., 2005). Future environments may involve novel combinations of increased atmospheric $\mathrm{CO}_{2}$ (IPCC, 2007b), temperature, sea level, salinity (Michener et al., 1997), precipitation (Easterling et al., 2000) and hurricane activity (Webster et al., 2005). In their experiment conducted in floating freshwater marshes in the Mississippi River Delta, Middleton and McKee (2012) observed that species richness was not affected by $\mathrm{CO}_{2}$, water regime, salinity, or any of their interactions. However, density of germinating seeds and seedling biomass was influenced by the interaction of $\mathrm{CO}_{2}$ with water regime and salinity level. Salinity, which reduced seedling biomass, was the main treatment driving seedling response patterns, flooding had less effect, and the influence of $\mathrm{CO}_{2}$ was secondary to these. Other authors also mention that seed germination and/or seedling growth of most species decrease with increased salinity (Howard \& Mendelssohn, 2000; Brock et al., 2005; Middleton, 2009a). As a consequence, higher $\mathrm{CO}_{2}$ concentrations will not ameliorate stressful environments related to flooding or salinity levels, however, species dominance may change even if the total number of species does not (Middleton \& McKee, 2012).

Middleton (1999b) also confirmed that water regime has a key role in the germination of wetland species. Flooding forms a barrier to the germination of most of them (van der Valk \& Davis, 1978; Leck, 1989), and therefore, any climate change affecting the duration of flooding in swamps could affect the regeneration of species from the seed bank (Middleton, 2009d). A few studies suggest that seed bank densities shift spatially across regional watersheds in response to flood pulsing (Middleton, 1999b; Middleton, 2003) and disturbance (Middleton \& Wu, 2008). In particular, shifts in water availability associated with climatic temperature or precipitation, are likely to have local and landscape effects on the regeneration dynamics of these ecosystems (Middleton, 2009d). Differences of seed germination in response to water regime are species-specific (Baskin \& Baskin, 1998; Middleton, 1999), and an experiment conducted by Middleton (2009d) also confirms that seed banks from the same swamps respond differently to non-flooded versus flooded conditions. Thus, both drought and heavy rainfall have the potential to alter the regeneration dynamics of wetland ecosystems. Middleton (2009d) concludes that any climate change, which would alter hydrology, could limit the dispersal, germination, and regeneration of short-lived woody species from Taxodium distichum (bald cypress) swamps. Taxodium distichum may already be experiencing physiological stress related to the higher temperatures at the southern limits of its range (Middleton \& McKee, 2004). With climate warming, Taxodium distichum populations may be extirpated near the southern extreme of the range (Crumpacker et al., 2001; Middleton \& McKee, 2004).

\section{Woody encroachment}

Shirley and Battaglia (2006) also reported marsh loss along the northern Gulf of Mexico between the 1950s and the 1990s. In the Mississippi Delta, marsh was converted to open water along shorelines and in internal patches, but the majority of marsh loss was attributed to scrub-shrub encroachment. In the Coastal Plain, the main trend was replacement of agricultural areas by forest. Shirley and Battaglia (2006) 
concluded that marsh areas are especially vulnerable since they are not keeping pace with the spatial shifts in the aquatic to terrestrial transition as sea level rises.

In spite of investigating an old-field ecosystem instead of wetlands in the southeastern USA, Classen et al. (2010) also found that soil moisture exerted the largest influence on seedling emergence and establishment, either directly or due to other climatic change factors. Climatic change is altering communities in old-field and forested ecosystems (Chapin et al., 2000; Knapp \& Smith, 2001), and multiple climate change factors, such as changes in $\mathrm{CO}_{2}$, temperature and precipitation regimes, can interact in ways that make predicting their direct impact on ecosystems difficult (Pendall et al., 2004). It is unlikely that $\mathrm{CO}_{2}$ concentration had any direct effect on germination and seedling emergence, however, elevated atmospheric $\mathrm{CO}_{2}$ concentrations can lead to an increase in soil moisture (Dermody et al., 2007). Warming also affected seedling establishment primarily through its effects on soil moisture, and not directly. Besides, deleterious effects of warming were more prevalent under dry than wet conditions. However, the effect of warming was not always deleterious to establishment, for example, when elevated $\mathrm{CO}_{2}$ was combined with warming, seedling emergence was higher. Classen et al. (2010) conclude that atmospheric and climatic change can alter the dynamics of ecosystem succession. Moreover, altered successional trajectories may result in forests with structure and function quite different from those of present forests (Mohan et al., 2007; De Deyn, 2008).

In contrast to Middleton and McKee (2012), Beckage et al. (2006) predict decreased frequency of both fires and hurricanes in the southeastern United States, and suggest that this and the $\mathrm{CO}_{2}$ fertilization effect will shift pine savannas towards a forested state.

\section{The Great Lakes region}

\section{Predicted changes in forest communities}

General circulation models predict temperature increases of 3.11-3.67 ${ }^{\circ} \mathrm{C}$ and precipitation increases of 2-14\% over the southern Great Lakes region (Illinois, Indiana and Ohio) (Ehman et al., 2002), whereas for northern Wisconsin, even larger temperature changes (up to $5.8^{\circ} \mathrm{C}$ ) are projected (Scheller \& Mladenoff, 2005). Global climate change is expected to affect the growth, distribution and species composition of forests at several spatial and temporal scales (Graham et al., 1990; Randolph \& Lee, 1994; Loehle \& LeBlanc, 1996; Schenk, 1996; Lindner et al., 1997; Scheller \& Mladenoff, 2005). Ehman et al. (2002) examined the possible responses of tree species to a twofold $\mathrm{CO}_{2}$-changed climate scenario, and found an overall decrease in total basal area for northern conifers and northern deciduous species. The total basal area of intermediate and southern species increased only slightly under the effects of climate change (with the exception of northern red oak - Quercus rubra, the basal area of which decreased). Table 9 shows how population centroids of different species groups are expected to shift under baseline as well as changed climate conditions by 2060. Ehman et al. (2002) also predicted how population centroids of regionally dominant species will shift after 80 years (Table 10). 
Table 9. Direction of predicted shifts for different species groups under baseline and changed climate conditions and predicted distance between the baseline and changed climate centroids by 2060 (Ehman et al., 2002)

\begin{tabular}{|l|c|c|c|}
\hline & $\begin{array}{c}\text { Under baseline } \\
\text { conditions }\end{array}$ & $\begin{array}{c}\text { Under changed } \\
\text { conditions }\end{array}$ & $\begin{array}{c}\text { Distance between } \\
\text { centroids }\end{array}$ \\
\hline Northern conifers & east-southeast & north-westward & $252.6 \mathrm{~km}$ \\
\hline $\begin{array}{l}\text { Northern deciduous } \\
\text { species }\end{array}$ & eastward & $\begin{array}{c}\text { northward and } \\
\text { eastward }\end{array}$ & $140.2 \mathrm{~km}$ \\
\hline Intermediate species & & eastward & $22.4 \mathrm{~km}$ \\
\hline Southern species & & north-eastward & $32.0 \mathrm{~km}$ \\
\hline
\end{tabular}

Table 10. Direction of predicted shifts of regionally dominant species under baseline and changed climate conditions by 2060 (Ehman et al., 2002)

\begin{tabular}{|l|c|c|}
\hline & Under baseline conditions & Under changed conditions \\
\hline $\begin{array}{l}\text { White oak (Quercus alba) } \\
\text { Plabnut hickory (Carya }\end{array}$ & stationary & eastward \\
\hline $\begin{array}{l}\text { Black oak (Quercus } \\
\text { velutina) }\end{array}$ & stationary & eastward \\
\hline $\begin{array}{l}\text { Northern red oak } \\
\text { (Quercus rubra) }\end{array}$ & eastward \\
\hline $\begin{array}{l}\text { Sugar maple (Acer } \\
\text { saccharum) }\end{array}$ & southwest & eastward \\
\hline $\begin{array}{l}\text { American beech (Fagus } \\
\text { grandifolia) }\end{array}$ & southward & north-eastward \\
\hline
\end{tabular}

According to the simulations, a significant change will be the loss of northern conifers and northern deciduous species from the study region. Under changed climate conditions, sugar maple (Acer saccharum) and thus the northern deciduous group may be eliminated. These results are in line with other studies suggesting that for northern conifer and northern deciduous species' populations, climate change either initiates a northward shift of the current range, a decline in dominance, or complete extirpation (Zabinski \& Davis, 1989; Randolph \& Lee, 1994; He et al., 1999). He et al. (1999) showed similar decreases in northern coniferous and some northern hardwood species in Wisconsin, predicting that the biomass of red pine (Pinus resinosa), quaking aspen (Populus tremuloides) and big-toothed aspen (Populus grandidentata) will decrease under a $5{ }^{\circ} \mathrm{C}$ temperature increase. Thus, these species might not be able to establish under warmer conditions.

For the intermediate and southern species, the effect of climate change is expected to be minor (Ehman et al., 2002). However, these results differ from those of other authors. Randolph and Lee (1994) reported community- and species-level responses of midwestern forests under a twofold $\mathrm{CO}_{2}$ changed climate scenario. Both the southern mixed forests and the southern oak-hickory-pine forests were predicted to expand northward from their current ranges to areas formerly occupied by northern hardwood, beech-maple, elm-ash, mixed-mesophytic, Appalachian oaks, and northern and central 
oak-hickory forests. In turn, ranges of these more northern forest types were predicted to shift to the north. In southern Indiana, oak-hickory forest is expected to change to a southern mixed forest dominated by southern red oak (Quercus falcata), post oak (Quercus stellata), bur oak (Quercus macrocarpa), and loblolly pine (Pinus taeda) (Randolph \& Lee, 1994), which is consistent with USEPA (1998) predictions. However, the expected shift towards southern oaks and hickory may be delayed because of seed dispersal limitations (Scheller \& Mladenoff, 2005). Zabinski and Davis (1989) proposed that for the Great Lakes region an increase in temperature would probably result in drier conditions due to increased evapotranspiration, so beech populations might be expected to decline.

Nevertheless, Ehman et al. (2002) add that if the time frame of the simulation had been extended, the northern species groups would have been completely eliminated, and larger increases in the southern species would have been evident. Additionally, as the mentioned shift could occur in a relatively short time, some understory woody and herbaceous species associated with the northern deciduous tree community also would probably disappear from the region if they could not adapt to conditions in the oakhickory dominated forests. Furthermore, Ehman et al. (2002) predict the loss of genetic diversity along range margins and that relict communities may also be regionally extirpated.

The above results are partly in line with those of Ravenscroft et al. (2010), who simulated shifts in forest composition under climate change in Minnesota, taking into account forest management scenarios as well. They observed a trend toward homogenization of forest conditions due to the widespread expansion of maple (Acer spp.). White spruce (Picea glauca), balsam fir (Abies balsamea), and paper birch (Batula papyrifera) were extirpated from the landscape, and additional losses of black spruce (Picea mariana), red pine (Pinus resinosa) and jack pine (Pinus banksiana) were projected in the high-emissions scenario. The loss of the above species is simulated by Scheller and Mladenoff (2005) as well, regardless of disturbance scenario. Ravenscroft et al. (2010) conclude that ensuring a diversity of species and conditions within forested landscapes may be the most effective means of ensuring the future resistance of ecosystems to climate-induced declines in productivity.

\section{Predicted changes in bog and fen communities as well as in wetlands}

Weltzin et al. (2000b) conducted experiments in Minnesota in order to investigate effects of climate change on bogs (dominated by Sphagnum mosses, ericaceous shrubs and black spruce - Picea mariana) and fens (dominated by graminoids, nonericaceous shrubs and trees). They concluded that the structure and function of both bog and fen plant communities will change, in different directions or at different magnitudes, in response to global or regional warming and changes in water-table elevation. Within each community, the response of plants was life-form- and species-specific (Table 11). According to the results, global warming may lead to an increase in the production and abundance of woody plants (in particular bog rosemary - Andromeda glaucophylla) in bog communities. In addition, lowered water-table elevations will also favour woody plants (Gorham, 1991). As a consequence, warm, dry bog plots may become dominated by shrubs in the future. 
Table 11. Effects of increasing water-table elevation and infrared loading on different plant functional types in bog and fen communities (Weltzin et al., 2000b)

Bogs

\begin{tabular}{|l|c|c|c|}
\hline & $\begin{array}{c}\text { Production of } \\
\text { bryophytes }\end{array}$ & $\begin{array}{c}\text { Production of } \\
\text { graminoids }\end{array}$ & $\begin{array}{c}\text { Production of } \\
\text { shrubs }\end{array}$ \\
\hline $\begin{array}{l}\text { Increasing water- } \\
\text { table elevation }\end{array}$ & $\uparrow$ & unaffected & $\downarrow$ \\
\hline $\begin{array}{l}\text { Increasing infrared } \\
\text { loading }\end{array}$ & unaffected & $\downarrow$ & $\uparrow$ \\
\hline
\end{tabular}

Fens
\begin{tabular}{|l|c|c|c|}
\hline & $\begin{array}{c}\text { Production of } \\
\text { graminoids }\end{array}$ & $\begin{array}{c}\text { Production of } \\
\text { forbs }\end{array}$ & $\begin{array}{c}\text { Production of } \\
\text { shrubs }\end{array}$ \\
\hline $\begin{array}{l}\text { Increasing water- } \\
\text { table elevation }\end{array}$ & $\uparrow$ & $\uparrow$ & unaffected \\
\hline $\begin{array}{l}\text { Increasing infrared } \\
\text { loading }\end{array}$ & $\uparrow$ & $\downarrow$ & unaffected \\
\hline
\end{tabular}

Climate change is predicted to reduce water levels of the Laurentian Great Lakes, altering coastal wetland ecosystems and potentially stimulating invasive macrophytes, such as Typha $x$ glauca (white cattail) (Lishawa et al., 2010). According to a field study conducted by Lishawa et al. (2010) in intact northern Great Lakes coastal wetlands, plant community composition had shifted and became more homogeneous than it was 20 years before, due to an invasion by Typha $x$ glauca. Beach ridges usually protect Typha $x$ glauca from wave and seiche energy, and as water levels decline, these energyinsulating microtopographic features will likely stimulate further invasion and dominance by this species, even in high quality wetlands (Lishawa et al., 2010).

\section{The Great Plains}

Altered fire regimes have the potential to cause major changes in plant community composition and structure (Bond et al., 2005; Nowacki \& Abrams, 2008). In ecotones, many species are at the limits of their natural ranges, therefore vegetation may be especially sensitive to the combined effects of increased temperatures, droughts, and changes in land use and management (Gosz, 1992; Risser, 1995). Even a small change in climate can lead to major changes in vegetation in these communities, often in combination with rapid encroachment of invasive species (Allen \& Breshears, 1998; DeSantis et al., 2011). An increase in the number, severity and duration of droughts due to global climate change may lead to rapid transformations becoming more common (Allen et al., 2010).

In south-central North America, drought and decreased fire frequency were responsible for changes in the composition and structure of oak (Quercus)-dominated forests over fifty years (Rice \& Penfound, 1959; DeSantis et al., 2010). Besides, grazing may have played a minor role as well (DeSantis et al., 2011). Although these forests had exhibited changes in dominance from xeric fire-tolerant Quercus to mesic fire-intolerant tree species (DeSantis et al., 2010), the most significant change was the rapid 
encroachment of the native invasive eastern red cedar (Juniperus virginiana) due to fire suppression in this midcontinent forest-prairie ecotone (DeSantis et al., 2011). DeSantis et al. (2011) suggest that future forests subjected to fire suppression and more frequent and prolonged droughts will likely undergo continued changes in species composition.

Frelich and Reich (2010) predict a "savannification" of the forest on the prairieforest border, owing to the loss of adult trees. This is expected to be caused by the greater frequency of droughts, fires, forest-leveling windstorms, and outbreaks of native and exotic insect pests and diseases. As a consequence, this biome boundary is predicted to shift to the northeast just like during past episodes of global warming, but in a greater magnitude and more rapidly than as if it would be solely attributable to the direct effects of temperature change.

\section{Intermontane basins and plateaus}

Water availability is the primary constraint to plant productivity in many terrestrial biomes (Rosenzweig, 1968; Webb et al.,1986; Le Houerou et al., 1988; Churkina \& Running, 1998), and it is an ecosystem driver that will be strongly affected by ongoing and future climate change (Houghton et al., 2001). The within-season distribution of precipitation events has significant effects on plant and soil processes (Novoplansky \& Goldberg, 2001; Knapp et al., 2002; Fay et al., 2003; Schwinning \& Sala, 2004; Sher et al., 2004; Harper et al., 2005; Sponseller, 2007) and thus, on community composition and dynamics (Graetz et al., 1988; Comstock \& Ehleringer, 1992; Ojima et al., 1993; Ehleringer et al., 1999). Global climate change scenarios predict a shift to larger precipitation events with longer intervening dry intervals (Groisman et al., 1999; Easterling et al., 2000; IPCC, 2007a). Community responses to altered precipitation patterns are a direct result of the timing of water availability within the soil profile (Brown et al., 1997; Schwinning et al., 2005). Ecological processes in arid and semiarid ecosystems are particularly sensitive to within-season dynamics (Schwinning \& Sala, 2004) as chronic water limitation defines this ecosystem (Parton et al., 1981) and strongly influences its physiological characteristics and species composition (Sala et al., 1992; Chesson et al., 2004).

In their experiments conducted in Colorado, Heisler-White et al. (2008) found that larger, less frequent rainfall events resulted in greater aboveground net primary productivity in the dominant grass in the shortgrass steppe, Bouteloua gracilis (blue grama grass). Although no significant relationship could be identified between mean event size or dry interval length and aboveground net primary productivity, similar to analyses in other grasslands (Nippert et al., 2006; Swemmer et al., 2007), the results suggest that the relative evenness of event size in combination with event number may have important effects on ecosystem function (Heisler-White et al., 2008).

Other studies have shown that reducing storm frequency and increasing rainfall quantity per storm decreases above-ground production in tall grass prairies of the central United States (Fay et al., 2002; Knapp et al., 2002). Shifting from a winter to a spring precipitation pattern reduces productivity in the sagebrush steppe of the northern Great Basin (Svejcar et al., 2003). Besides, atmospheric increases in $\mathrm{CO}_{2}$ and climate change also have the potential to increase the competitiveness of invasive weeds in arid lands (Smith et al., 2000). Bates et al. (2006) investigated the effects of altered timing of precipitation on vegetation dynamics in an Artemisia tridentata spp. wyomingensis (Wyoming big sagebrush) community in the northern Great Basin and observed that shifting precipitation distribution to a spring/summer pattern has the greatest potential 
for altering productivity, composition, and structure of Artemisia tridentata steppe vegetation. Annual and perennial forbs native to the system were the least resistant to a timing change, declining in density, cover, and biomass. As a consequence, a long-term shift to a spring/summer dominated precipitation pattern would lead to the forb component being lost or severely reduced, and to an increase in bare ground, with the potential to reduce ecosystem biodiversity. Increased winter precipitation combined with summer drought, however, appears unlikely to cause major changes to vegetation composition or productivity (Bates et al., 2006). Nevertheless, if temperature increases as predicted by general circulation models (NAST, 2000; IPCC, 2001), the potential exists for increased annual grass establishment into areas where it is still a minor component of the Artemisia tridentata ecosystem. The increase in Bromus tectorum (cheatgrass) is of concern as its presence has altered historic fire regimes and permanently modified Great Basin plant communities (Young et al., 1987). Thus, a warmer environment coupled with a winter precipitation regime and greater $\mathrm{CO}_{2}$ levels would likely permit invasion and dominance by Bromus tectorum, particularly if fire disturbances increase (Bates et al., 2006). The results of Bates et al. (2006) also demonstrate the resilience of these communities to climate perturbation as many of the vegetation shifts did not begin until the fourth year after treatments were applied.

\section{Rocky Mountains and the Cascades}

\section{Changes in forest communities}

In Washington State, conifer species dominate forest ecosystems with hardwood species abundant only in riparian areas (Littell et al., 2010). Both snowpack declines and warmer summers are projected, thus, summer water availability for plants will likely decrease in Washington forests (Elsner et al., 2010; Mote \& Salathé, 2010). Littell et al. (2010) predict that the area of forest that is severely water-limited will likely increase by the 2020s and even in a greater magnitude by the 2040s and the 2080s. These changes are projected to occur on the east side of the Cascade Mountains and west side of the Rocky Mountains in the northern part of Washington State. According to Littell et al. (2010), Douglas-fir (Pseudotsuga sp.) is possibly one of the most climate-sensitive species regionally, thus, it may be in increasing risk at the edges of its current range in Washington. This is probably due to increases in temperature and decreases in growing season water availability in more arid environments, e.g., in the Columbia Basin. The decline in climatically suitable habitat for Douglas-fir is most widespread at lower elevations. In pine forests, climate is likely to be a significant stressor in the Columbia Basin and eastern Cascades by the 2060s (Littell et al., 2010), and projections suggest that areas with climatic conditions favourable for lodgepole pine (Pinus contorta) will decrease considerably. Littell et al. (2010) also conclude that in the future, the rate of forest change (change in forest type, species composition and productivity) in response to climate change will likely be driven more by disturbances (such as increases in fire area and outbreaks by mountain pine beetle) than by gradual changes in tree populations. Sudden changes to forest structure and composition caused by stand-replacing disturbances will speed up species turnover and transitions to new structural characteristics of stands and landscapes. According to Busing et al. (2007), frequent fires of low severity can alter forest composition and structure as much or more than severe fires at historic frequencies. 
An overall decrease is predicted in pine-dominated subalpine forests in the Greater Yellowstone Ecosystem as well (Schrag et al., 2008). In simulations by Schrag et al. (2008), temperature and temperature-related variables appeared to be the most influential in the distribution of whitebark pine (Pinus albicaulis), whereas precipitation and soil variables dominated in the case of subalpine fir (Abies lasiocarpa) and Engelmann spruce (Picea engelmannii). As tree-line conifers are believed to be limited by temperature, they may serve as important indicators of climate change. Romme and Turner (1991) add that the upper and lower timberline appear to be particularly sensitive to climate change. The upper timberline is likely to migrate upward in elevation in response to temperature changes, whereas the lower treeline may retreat under drier conditions or move down slope under wetter conditions. According to their simulations, the extent of alpine vegetation is expected to decrease.

Besides, species with relatively narrow niches, such as plants endemic to particular soils, may be especially vulnerable to extinction under a changing climate due to the enhanced difficulty they face in migrating to suitable new sites (Damschen et al., 2010). Damschen et al. (2010) observed sharp declines in herb cover and richness in the Siskiyou Mountains of southern Oregon. Declines were the strongest in species of northern biogeographic affinity, species endemic to the region, and species endemic to serpentine soils. Overall, herb communities have shifted to more closely resemble communities found on xeric south-facing slopes.

As for the rate of forest change, Elliott (2011) suggests that considerable lag times exist between changes in climate towards more favourable growing conditions and corresponding shifts in tree establishment at the upper tree line in the Rocky Mountains.

\section{Changes in herbaceous communities}

Results from warming experiments show that two primary microclimate effects of warming are a decrease in soil moisture and an increase in nitrogen mineralization (Harte et al., 1995; Shaw \& Harte, 2001). In their experiment conducted in the Rocky Mountains of Colorado, Harte and Shaw (1995) found that in the warmed plots, aboveground biomass of forbs decreased, that of shrubs increased, and that of grasses was unchanged.

Harte et al. (2006) came to similar results in their warming experiment in a montane grassland in the Colorado Rockies. They also found an increase in the aboveground biomass of sagebrush (Harte \& Shaw, 1995; Perfors et al., 2003), and an approximately compensating decline in that of forbs, especially the shallow-rooted ones (Harte \& Shaw, 1995; Saveedra et al., 2003; de Valpine \& Harte, 2001a), whereas biomass in grasses showed no response to warming. Harte et al. (2006) concluded that the shift in primary production is associated with shifting species composition in the plant community.

De Valpine and Harte (2001b) observed in their study on 11 forb species in a montane meadow that six of those responded to warming with significant changes either in abundance, average size, flowering, or in frost damage. Some of these were favourable responses but most of them were negative. Regarding the two most abundant species, neither water nor nitrogen had a significant effect on the aboveground biomass of Helianthella quinquenervis (fivenerve helianthella), whereas Erigeron speciosus (aspen fleabane) responded to both nitrogen and water additions, but its response to water was larger than its response to nitrogen. Its final biomass increased significantly 
with water addition and marginally significantly with nitrogen addition, however, it declined strongly under warming.

\section{Central and South America}

\section{Effects of climate change on tree species}

In Mexico, drier conditions are predicted mainly for the northern part. By 2050 it is generally expected that several species will lose a significant portion of their area of distribution as a result of the impact of climate change (Trejo et al., 2011). For example, Fagus grandifolia var. mexicana (Mexican beech) is a dominant element of the cloud forest in Eastern Mexico. Under a predicted scenario characterized by $+2{ }^{\circ} \mathrm{C}$ and $-20 \%$ rainfall in the region, a drastic distribution contraction of this species can be expected (Tellez-Valdes et al., 2006). Zacarias-Eslava and del Castillo (2010) predict the expansion of chaparral at the expense of temperate forest and the extinction of highaltitude species in the Sierra Juarez. Comita and Engelbrecht (2009) also confirm that predicted shifts in rainfall patterns caused by global and regional climate change are expected to alter the dynamics, composition, and diversity of seasonal tropical forests. According to their studies in Panama, lower growth and higher mortality are expected at the community level in the dry season relative to the wet season and higher mortality is predicted in the drier plateau habitat relative to the wetter slope habitat.

Changes in the position along the elevational gradient for plant species are considered as a response to climate change (Alo \& Wang, 2008), particularly within the area of influence of cities, as a response to the effects of urban heat islands (Gómez et al., 1998; Jenerette et al., 2007). The impact of the urban heat island on plant community distribution has been documented in several studies (Zhao et al., 2006; Jenerette et al., 2007; Luo et al., 2007), regarding mountain areas as well (Schrag et al., 2008). When the climate gets warmer in response to the urban heat island, it can be expected that plant communities will migrate up along mountain sides, to new altitudinal limits (Lenoir et al., 2008). Studying seedling survival of Ceiba aesculifolia (pochote), a tropical tree species, along an altitudinal gradient in a slope facing the city of Morelia in Mexico, Valle-Díaz et al. (2009) observed a general increase in plant survival with elevation. The highest survival was found $160 \mathrm{~m}$ higher than the altitudinal limit of the remnant adult trees in the study area, and close to the highest limit reported for the species at a regional scale. These results suggest that establishment of Ceiba aesculifolia has shifted upward along the altitudinal gradient in the study area. Besides, the envelope of suitable temperatures for seedling establishment is expected to shift upward more on the south face of the mountains than in the slopes facing the north. Feeley et al. (2011) came to the same conclusion by observing in Peru that most of the studied tropical Andean tree genera shifted their mean distributions upslope in the first years of the $21^{\text {st }}$ century. The mean rate of migration was approximately 2.5-3.5 vertical metres upslope per year, and abundances of tree genera previously distributed at lower elevations increased in the majority of study plots. According to Feeley et al. (2011), the observed mean rate of change is less than predicted from the temperature increases for the region, possibly due to the influence of changes in moisture or non-climatic factors such as substrate, species interactions, lags in tree community response or dispersal limitations. Nevertheless, continued slower migration of tropical Andean trees would indicate a limited ability to respond to 
increased temperatures, which may lead to increased extinction risks with further climate change.

\section{Savannization and forest encroachment}

According to Bush and Hooghiemstra (2005), the impacts of climatic changes in the tropics can be severe. Future biodiversity may depend on changes in precipitation and land use patterns (Higgins, 2007). In Colombia and Venezuela, the southern boundary of the savanna vegetation, which is transitional to tropical rainforest, has migrated in the past (Behling \& Hooghiemstra, 1998). Shifts of this savanna-forest transition depend heavily on annual precipitation values and the length of the dry season, while temperature change has little impact (Hutyra et al., 2005; Flantua et al., 2007). The area of the Colombian savanna has small amplitude of annual temperature change which should not influence vegetation distribution significantly (Rippstein et al., 2001).

Collevatti et al. (2011) studied effects of climate change on savanna vegetation in Brazil and concluded that distribution of savanna tree species may be highly restricted in future climate conditions because suitable places will be localized in the most disturbed area of Brazil. For Caryocar brasiliense (pequi), a widespread savanna tree species, the highest levels of suitability of occurrence can be found throughout the central portion of Brazil, extending to northern South and Central America and in some core areas of the Amazon (Collevatti et al., 2011). According to projections by Collevatti et al. (2011), its overall geographical limits will be widely reduced (by about $50 \%$ ) by 2050 . Moreover, a distributional shift will occur in the structure of climatically suitable areas within the species' range toward the southeastern region (Diniz-Filho et al., 2010), and a strong reduction in genetic diversity is expected if habitat suitability drops below 0.5 with climate change. Although other projections inferred the savannization of tropical forests, with expansion of savanna-like vegetation in South America (Hutyra et al., 2005; Salazar et al., 2007), suitability for Caryocar brasiliense may be restricted to the southernmost distribution of savanna vegetation (Collevatti et al., 2011). It is also possible that this species will be unable to track the current climate change due to its pace and mainly due to the fragmentation of the habitat (Jump \& Peñuelas, 2005; Hoffmann \& Willi, 2008). According to Collevatti et al. (2011), the more suitable places for Caryocar brasiliense can be found in the most disturbed regions in Brazil in the future, with the most fragmented and degraded habitats due to human occupation. This will hold back population migration and persistence, and thus, these populations may have a limited capacity to cope with ongoing climatic changes.

Studying a forest-grassland mosaic at the southernmost limit of the Brazilian (Araucaria) Atlantic forest, Silva and Anand (2011) found a clear shift in vegetation cover, representing a continuous process of forest expansion. Both patch formation and border dynamics occurred simultaneously, promoting a forest encroachment of 50-100 $\mathrm{m}$ into grasslands in all forest-grassland borders. However, the rates of forest expansion (50-100 $\mathrm{m}$ for forest borders and up to $30 \mathrm{~m}$ radius for forest patches over the past 4,000 years) were orders of magnitude slower than what has been historically observed in other forest biomes, which could be caused by edaphic constraints (Silva \& Anand, 2011). On the other hand, trees have been colonizing a well-established, stable and highly diverse grass dominated ecosystem in the study site (Behling \& Pillar, 2007), which is fundamentally different from what has been observed in boreal systems, where due to low or no resistance from resident vegetation, forest expansion occurs at much faster rates. 
In contrast to the above results predicting forest expansion over savanna, Salazar and Nobre (2010) assume that tropical forests might be replaced by seasonal forests or savanna over eastern Amazonia with temperature increases of 2-5 ${ }^{\circ} \mathrm{C}$, when $\mathrm{CO}_{2}$ fertilization effect is not or partially considered. A precipitation decrease greater than $30 \%$ would also trigger the shift from tropical forest to drier biomes, such as savanna and shrubland in southeastern Amazonia. However, biome changes can be considerably smaller when the optimum fertilization effect is included.

\section{Effects of climate change on forest communities}

Several studies have shown evidence of expansion of tropical forests in different parts of the world (Dümig et al., 2008; Martinelli et al., 1996; Palmer \& van Rooyen, 1998; Puyravaud et al., 1994; Silva et al., 2008). The change from a colder and drier to a warmer and wetter climate after the last glacial period has promoted the expansion of water-limited forests (Dümig et al., 2008; Silva et al., 2008). In general, trees benefit more than grasses from the warmer interglacial periods that are associated with a higher atmospheric $\mathrm{CO}_{2}$ (Ehleringer et al., 1997). Additionally, a reduction in fire frequency as consequence of a relative reduction in grass biomass, along with greater water availability, would also favour the expansion of forests (Bond et al., 2003). Silva and Anand (2011) showed that forests have been expanding over grasslands through continuous, but very slow border dynamics and patch formation. Existing paleoevidence from southern biomes also indicates that forests have been expanding over grasslands and savannas during the past few millennia (Behling et al., 2004; Behling \& Pillar, 2007; Silva et al., 2008, 2011). This process coincided with past changes in climate, but biotic feedback mechanisms also appeared to be important.

Humid tropical forests depend on abundant and regular water supply and reductions in precipitation can lead to forest retraction (Behling, 2002; Pennington et al., 2004, 2006; Silva et al., 2009). Deciduous and xeromorphic forests on the other hand are adapted to strong seasonality in terms of water availability (Furley, 2007; Furley et al., 2006), and did not respond to past shifts in climate the same way as tropical humid forests. Silva et al. (2010) showed that deciduous forests covered greater areas in the past, however, despite an increase in tree cover and a decline in grasses, the extent of xeromorphic forest has remained stable. This contrasts with research that documented the expansion of riparian forests over savannas in the same region (Silva et al., 2008), and in the Amazon and Atlantic forests in northern and southern Brazil respectively (Dümig et al., 2008; Martinelli et al., 1996). Silva et al. (2010) assume that the continuous input of organic matter is the keystone for the maintenance of the xeromorphic forest structure.

Barlow and Peres (2008) predict a widespread dieback of Amazonian forest cover through reduced precipitation and emphasize the potential role of fire in the degradation of forest ecosystems as episodic wildfires can lead to drastic changes in forest structure and composition. Several future climate change scenarios project an increase in frequency and severity of droughts, which can cause long-term compositional shifts in many forest ecosystems. In Patagonia, Suarez and Kitzberger (2008) observed that drought-kill disturbance shifted species composition in favour of Austrocedus chilensis in a mixed Nothofagus dombeyi (coihue)-Austrocedrus chilensis (Chilean cedar) forest. 


\section{Summary list of main ideas and phenomena}

\section{North America in general}

- Shifts in species distributions are mainly driven by increases in temperature and changes in the moisture index.

- Ranges will shift not only northward and upward but in all directions.

- Local extinctions in the south of species ranges, colonisation of new habitats in the north.

\section{Canada}

- Increased temperatures countrywide, increasing winter precipitation but decreasing summer precipitation.

- Tundra and taiga are expected to decline, while temperate forests and woodland are predicted to increase.

- Reduction of arctic-alpine communities.

- In the Arctic, tall shrub tundra is encroaching into areas of dwarf shrub tundra.

- The Boreal Plain ecozone might shrink and give way to the Prairie ecozone.

- Northward expansion of tree line is expected.

- Lower water table $\rightarrow$ marsh complexes will dry out more often, shift to more xeric species.

- Reduction of wetland areas.

- Possible invasion by southern exotic species.

- Increased fire season length and area burned in forested regions.

- Changes in fire interval may alter forest regeneration and cause shifts between deciduous- and conifer-dominated succession trajectories.

\section{The United States in general}

- Relatively large increases in temperature and decreases in precipitation in the eastern half of the country; increases in precipitation and relatively small increases in temperature in the West; significantly drier conditions in the South and in the central United States.

- Considerable uncertainty about possible future ecological impacts.

- Moderate warming could produce increased vegetation growth but greater warming could also produce large areas of drought stress.

- Projected changes in vegetation for the $21^{\text {st }}$ century: shift of current vegetation types, emergence of tropical forest as a new vegetation type, forecast changes vary according to models and scenarios.

- Potential expansion of temperate conifer forests.

- Possibly decreasing area of northeast mixed forest, tundra and alpine vegetation.

\section{Alaska}

- A warming trend has been observed, further warming is anticipated.

- Warmer air and soil temperatures $\rightarrow$ alteration of soil water and nutrient availability, permafrost thaw and ground subsidence $\rightarrow$ altering hydrological patterns. 
- Changes in environmental conditions may result in changes in plant community composition, biomass and productivity as well as in plant species shifts.

- In the High Arctic, areas with sparse vegetation and deep active layers may develop a thicker and more wide-spread layer of moss.

- In the Low Arctic, deciduous shrubs may dominate.

- Increased temperatures have been observed to promote shrub expansion, moist tussock tundra would give way to moist low shrub tundra.

- Possible increases in boreal forest due to increased growing season and warmer temperatures, however, thermokarsts can collapse boreal forests.

- Gradual elimination of conifer species and an increase in abundance of hardwood species with winter warming scenarios $\rightarrow$ possible shift to mixed broadleaf-needleleaf tree composition.

- Evergreen forests may expand into current tundra while being replaced by grasslands or temperate forest at the biome's southern edge.

- Longer and warmer summers can increase fire frequency. $\rightarrow$ The area burned is expected to increase. $\rightarrow$ Alaska may become a net carbon source.

\section{California}

- Substantially warmer and wetter winters, somewhat warmer summers and an enhanced El Niño Southern Oscillation, direction of change in precipitation is not clear.

- Both upward and downward shifts in species' optimum elevations.

- In tidal marshes, salinity has increased. $\rightarrow$ Increased cover of the most salttolerant plant species and decreased cover of the least salt-tolerant ones.

- According to a warmer and wetter scenario, expansion of forests and a net increase in evergreen conifer forest can be expected as well as the advancement of grassland.

- Under a drier and cooler scenario, the expansion of grassland is predicted along with a net decline in evergreen conifer forest, mixed evergreen woodland and shrubland.

- Significant declines in the extent of alpine/subalpine forest.

- Replacement of evergreen conifer forest by mixed evergreen forest or by woodland, shrubland or grassland.

\section{Southwestern USA}

- A warmer and drier climate is predicted.

- Changing precipitation regimes, increases in nutrient and water availability and soil disturbance may enhance the susceptibility of habitats to invasion by nonnative plant species (e.g. in the Mojave Desert).

- Accelerated plant mortality due to climate warming and drought.

- Shifts in vegetation distribution are expected to be the most rapid at ecotones, e.g. between ponderosa pine forest and pinon-juniper woodland.

- Large-scale shifts in dominance from grasses to shrubs or vice versa, depending on the amount and seasonality of precipitation.

- Compositional and structural changes of grassland vegetation are predicted. 
- Expected declines in stream base flows and water tables or increased flood intensity $\rightarrow$ shifts in functional types and vegetation structure.

\section{Eastern USA}

- Increases in annual temperature and precipitation in New England.

- Large-scale changes are predicted in the distribution of natural vegetation and considerable northward shift of both the northern and southern boundaries of the biomes.

- Significant reduction and upslope retreat of boreal conifer forest in New England.

- Mixed oak-hickory forests are expected to shift northward and increase in area.

- Northern deciduous hardwoods are expected to decrease in area and move upslope.

- Vascular plants have been replacing bryophytes in the alpine zone, alpine communities are in danger of regional extinction.

- Possible displacement of individual species: Pinus taeda may shift over 400 km northward.

- Coastal plant communities may be affected by the projected increase in sea level as well as by drought.

- Distribution patterns of shrub thickets are influenced by variations in transpiration caused by environmental changes.

- Possible drying up of bogs in the Southern Appalachian Mountains $\rightarrow$ they may become a carbon source.

- Salt marsh communities may be resilient to modest warming and large changes in precipitation.

\section{Southeastern USA}

- Future climate is predicted to become warmer and drier.

- In the Greater Everglades region of southern Florida, an increase in salinity of the vadose zone is expected due to sea level rise and storm surges. $\rightarrow$ Potential eradication of the salinity-intolerant hardwood hammocks at higher elevations and landward migration of mangroves.

- In wetlands, changes in hydrological properties (sea level, duration and depth of flooding, seasonal variation in rainfall) control plant distribution.

- In coastal ecosystems, regeneration (seed germination and seedling growth) may be dictated by disturbances related to hurricanes, water fluctuation and saltwater intrusion.

- Alteration of hydrology could limit the dispersal, germination and regeneration of short-lived woody species from Taxodium distichum swamps.

- Marsh loss due to scrub-shrub encroachment.

- Replacement of abandoned agricultural areas by forest.

- Potential shift of pine savannas towards a forested state, due to decreased frequency of fires and hurricanes as well as the $\mathrm{CO}_{2}$ fertilization effect.

\section{The Great Lakes region}

- Temperature and precipitation increases are predicted. 
- An overall decrease in total area for northern conifers and northern deciduous species is expected, northward shift of the current range, decline in dominance or complete extirpation.

- Southern mixed forests and southern oak-hickory-pine forests are predicted to expand northward.

- A trend toward homogenization of forest conditions due to the widespread expansion of Acer spp.

- In bog communities, an increase in the production and abundance of woody plants is expected due to warming and lowered water-table elevations.

- In coastal wetlands, plant community composition has shifted and become more homogeneous due to an invasion by Typha $x$ glauca.

\section{The Great Plains}

- Drought and decreased fire frequency $\rightarrow$ changes in dominance from xeric fire-tolerant Quercus to mesic fire-intolerant tree species, rapid encroachment of Juniperus virginiana.

- "Savannification" of the forest on the prairie-forest border $\rightarrow$ biome boundary is predicted to shift to the northeast.

\section{Intermontane basins and plateaus}

- Major role of water availability and within-season distribution of precipitation events.

- In Colorado shortgrass steppe, the relative evenness of rainfall event size in combination with event number may have important effects.

- Shifting precipitation distribution to a spring/summer pattern has the greatest potential for altering productivity, composition and structure of Artemisia tridentata steppe vegetation $\rightarrow$ loss of forbs, increase in bare ground.

- A warmer environment coupled with a winter precipitation regime, greater $\mathrm{CO}_{2}$ levels and increased fire disturbances would likely permit invasion and dominance by Bromus tectorum.

\section{Rocky Mountains and the Cascades}

- In Washington State, snowpack declines and warmer summers are projected. $\rightarrow$ Area of forest that is severely water-limited will likely increase.

- Pseudotsuga sp. is possibly one of the most climate-sensitive species.

- Areas with climatic conditions favourable for Pinus contorta will decrease considerably.

- The rate of forest change in response to climate change will mainly be driven by disturbances.

- An overall decrease is predicted in pine-dominated subalpine forests in the Greater Yellowstone Ecosystem.

- The upper and lower timberline appear to be particularly sensitive to climate change, the former one is likely to migrate upward in elevation, whereas the lower treeline may retreat under drier conditions or move down slope under wetter conditions.

- The extent of alpine vegetation is expected to decrease. 
- Due to warming, aboveground biomass of forbs may decrease, that of shrubs may increase, whereas that of grasses may remain unchanged.

\section{Central and South America}

- In Mexico, drier conditions are predicted mainly for the northern part.

- In case of warming and reduction in rainfall, a drastic distribution contraction of Fagus grandifolia var. mexicana can be expected.

- Potential expansion of chaparral at the expense of temperate forest and possible extinction of high-altitude species.

- Climate gets warmer in response to urban heat islands as well. $\rightarrow$ Plant communities are expected to migrate upwards in mountains.

- Most of the tropical Andean tree genera shifted their mean distributions upslope in the first years of the $21^{\text {st }}$ century.

- Shifts of the savanna-forest transition depend heavily on annual precipitation values and the length of the dry season.

- In Brazil, suitable areas for savanna tree species will be localized in the most disturbed regions, with the most fragmented and degraded habitats. $\rightarrow$ Geographical limits of Caryocar brasiliense are predicted to be widely reduced.

- Expansion of savanna-like vegetation in South America.

- At the southernmost limit of the Brazilian Atlantic forest, a continuous but slow process of forest expansion has been observed.

- Tropical forests might be replaced by seasonal forests or savanna over eastern Amazonia with temperature increases or precipitation decrease.

- Potential widespread dieback of Amazonian forest cover through reduced precipitation.

- Fire may have a significant role in the degradation of forest ecosystems.

Acknowledgements. This work was supported by the Bolyai János Research Scholarship of the MTA Doctoral Council, „ALÖKI” Applied Ecological Research and Forensic Institute Ltd., and the TÁMOP 4.2.1/B-09/1/KMR-2010-0005 project.

\section{REFERENCES}

[1] Abel, G.W. (1941): Factors influencing the natural establishment of forest trees on abandoned land.- Cornell University, Ithaca.

[2] Ackerly, D.D. (2003): Community assembly, niche conservatism, and adaptive evolution in changing environments. - Int. J. Plant Sci. 164: S165-S184.

[3] Adams, H.D., Guardiola-Claramonte, M., Barron-Gafford, G.A., Villegas, J.C., Breshears, D.D., Zou, C.B., Troch, P.A., Huxman, T.E. (2009): Temperature sensitivity of drought-induced tree mortality portends increased regional die-off under globalchange-type drought. - Proceedings of the National Academy of Sciences of the United States of America 106(17): 7063-7066.

[4] Allen, C.D., Breshears, D.D. (1998): Drought-induced shift of a forest-woodland ecotone: Rapid landscape response to climate variation. - Proceedings of the National Academy of Sciences of the United States of America 95(25): 14839-14842. 
[5] Allen, C.D. (2007): Interactions across spatial scales among forest dieback, fire, and erosion in northern New Mexico landscapes. - Ecology 10: 797-808.

[6] Allen, M.R., Frame, D.J., Huntingford, C., Jones, C.D., Lowe, J.A., Meinshausen, M., Meinshausen, N. (2009a): Warming caused by cumulative carbon emissions towards the trillionth tonne. - Nature 458: 1163-1166.

[7] Allen, C.D., Macalady, A.K., Chenchouni, H., Bachelet, D., McDowell, N.G., Vennetier, M., Kitzberger, T., Rigling, A., Breshears, D.D., Gonzales, P., Hogg, E.H., Fensham, R., Zhang, Z., Castro, J., Lim, J.H., Allard, G., Running, S.W., Semerci, A., Cobb, N.S. (2009b): A global overview of drought and heat-induced tree mortality reveals emerging climate change risks for forests. - For. Ecol. Manag. 259: 660-684.

[8] Allen, C.D., Macalady, A.K., Chenchouni, H., Bachelet, D., McDowell, N., Vennetier, M., Kitzberger, T., Rigling, A., Breshears, D.D., Hogg, E.H., Gonzalez, P., Fensham, R., Zhang, Z., Castro, J., Demidova, N., Lim, J.-H., Allard, G., Running, S.W., Semerci, A., Cobb, N. (2010): A global overview of drought and heat-induced tree mortality reveals emerging climate change risks for forests. - Forest Ecol. Manage. 259: 660-684.

[9] Alo, C.A., Wang, G.L. (2008): Potential future changes of the terrestrial ecosystem based on climate projections by eight general circulation models. - J. Geophys. Res.-Biogeosci. 113: G01004.

[10] Anderson, J.C., Craine, I., Diamond, A.W., Hansell, R. (1998): Impacts of Climate Change and Variability on Unmanaged Ecosystems, Biodiversity and Wildlife. - In: Koshida, G., Avis, W. (eds.) National Sectoral Volume, Canada Country Study: Climate Impacts and Adaptation: Volume VII, Environment Canada, Toronto.

[11] Andreadis, K.M., Clark, E.A., Wood, A.W., Hamlet, A.F., Lettenmaier, D.P. (2005): Twentieth-century drought in the conterminous United States. - J. Hydrometeorol. 6: 985-1001.

[12] Arft, A.M., Walker, M.D., Gurevitch, J., Alatalo, J.M., Bret-Harte, M.S., Dale, M., Diemer, M., Gugerli, F., Henry, G.H.R., Jones, M.H., Hollister, R.D., Jonsdottir, I.S., Laine, K., Levesque, E., Marion, G.M., Molau, U., Molgaard, P., Nordenhall, U., Raszhivin, V., Robinson, C.H., Starr, G., Stenstrom, A., Stenstrom, M., Totland, O., Turner, P.L., Walker, L.J., Webber, P.J., Welker, J.M., Wookey, P.A. (1999): Responses of tundra plants to experimental warming: meta-analysis of the international tundra experiment. - Ecol. Monogr. 69: 491-511.

[13] Armentano, T.V., Sah, J.P., Ross, M.S., Jones, D.T., Cooley, H.C., Smith, C.S. (2006): Rapid responses of vegetation to hydrological changes in Taylor Slough, Everglades National Park, Florida, USA. - Hydrobiologia 569: 293-309.

[14] Axelrod, D.I. (1985): Rise of the grassland biome, central North America. - Bot. Rev. 51: 163-201.

[15] Bachelet, D., Neilson, R.P., Lenihan, J.M., Drapek, R.J. (2001): Climate Change Effects on Vegetation Distribution and Carbon Budget in the United States. - Ecosystems 4: 164 185.

[16] Bachelet, D., Neilson, R.P., Hickler, T., Drapek, R.J., Lenihan, J.M., Sykes, M.T., Smith, B., Sitch, S., Thonicke, K. (2003): Simulating past and future dynamics of natural ecosystems in the United States. - Global Biogeochemical Cycles 17(2): 1045

[17] Bachelet, D., Lenihan, J., Neilson, R., Drapek, R., Kittel, T. (2005): Simulating the response of natural ecosystems and their fire regimes to climatic variability in Alaska. Canadian Journal of Forest Research-Revue Canadienne de Recherche Forestiere 35(9): 2244-2257.

[18] Bard, G.E. (1952): Secondary succession on the Piedmont of New Jersey. - Ecol. Monogr. 22: 195-215.

[19] Barlow, J., Peres, C.A. (2008): Fire-mediated dieback and compositional cascade in an Amazonian forest. - Philosophical Transactions of the Royal Society B-Biological Sciences 363(1498): 1787-1794. 
[20] Barrett, T.M., Gray, A.N. (2011): Potential of a national monitoring program for forests to assess change in high-latitude ecosystems. - Biological Conservation 144: 1285-1294.

[21] Bartha, S., Meiners, S.J., Pickett, S.T.A., Cadenasso, M.L. (2003): Plant colonization windows in a mesic old field succession. - Appl. Veg. Sci. 6: 205-212.

[22] Bartha S., Zimmermann Z., Szentes Sz., Sutyinszki Zs., Szabó G., Házi J., Komoly C., Penksza K. (2010): High resolution vegetation assessment with beta-diversity - a moving window approach. Agrárinformatika / Agricultural Informatics (2010) Volume 9: 1-9. (http://journal.magisz.org)

[23] Bartha S., Szentes Sz., Horváth A., Házi J., Zimmermann Z., Molnár Cs., Dancza I., Margóczi K., Pál R., Purger D., Schmidt D., Óvári M., Komoly C., Sutyinszki Zs., Szabó G., Csathó A. I., Juhász M., Penksza K., Molnár Zs. (2014): Impact of mid-successional dominant species on the diversity and progress of succession in regenerating temperate grasslands. Applied Vegetation Science 17(2): 201-213.

[24] Baskin, C.C., Baskin, J.M. (1998): Seeds, ecology, biogeography, and evolution of dormancy and germination. - Academic Press, San Diego.

[25] Bates, J.D., Svejcar, T., Miller, R.F., Angell, R.A. (2006): The effects of precipitation timing on sagebrush steppe vegetation. - Journal of Arid Environments 64(4): 670-697.

[26] Bazzaz, F.A. (1968): Succession on abandoned fields in the Shawnee Hills, southern Illinois. - Ecology 49: 924-936.

[27] Beck, P.S.A., Juday, G.P., Alix, C., Barber, V.A., Winslow, S.E., Sousa, E.E., Heiser, P., Herriges, J.D., Goetz, S.J. (2011): Changes in forest productivity across Alaska consistent with biome shift. - Ecology Letters 14(4): 373-379.

[28] Beckage, B., Gross, L.J., Platt, W.J. (2006): Modelling responses of pine savannas to climate change and large-scale disturbance. - Applied Vegetation Science 9(1): 75-82.

[29] Beckage, B., Osborne, B., Gavin, D.G., Pucko, C., Siccama, T., Perkins, T. (2008): A rapid upward shift of a forest ecotone during 40 years of warming in the Green Mountains of Vermont. - Proceedings of the National Academy of Sciences of the United States of America 105(11): 4197-4202.

[30] Behling, H., Hooghiemstra, H. (1998): Late Quaternary palaeoecology and palaeoclimatology from pollen records of the savannas of the Llanos Orientales in Colombia. - Palaeogeogr. Palaeoclimatol. Palaeoecol. 139: 251-267.

[31] Behling, H. (2002): South and Southeast Brazilian grasslands during late Quaternary times: a synthesis. - Palaeogeogr. Palaeoclimatol. Palaeoecol. 177: 19-27.

[32] Behling, H., Pillar, V., Orloci, L., Bauermann, S. (2004): Late Quaternary Araucaria forest, grassland (Campos), fire and climate dynamics, studied by high-resolution pollen, charcoal and multivariate analysis of the Cambar do Sul core in southern Brazil. Palaeogeogr. Palaeoclimatol. Palaeoecol. 203: 277-297.

[33] Behling, H., Pillar, V. (2007): Late Quaternary vegetation, biodiversity and fire dynamics on the southern Brazilian highland and their implication for conservation and management of modern Araucaria forest and grassland ecosystems. - Philos. Trans. R. Soc. B. Biol. Sci. 362: 243.

[34] Bélanger, N., Pinno, B.D. (2008): Carbon sequestration, vegetation dynamics and soil development in the Boreal Transition ecoregion of Saskatchewan during the Holocene. Catena 74: 65-72.

[35] Bering Sea Impacts Study (BESIS) (1997) The impacts of global climate change in the Bering Sea region: an assessment conducted by the International Arctic Science Committee. - In: Results of a Workshop, Birdwood, AK, 18-21 September 1996. Publ. BESIS Project Office, University of Alaska, Fairbanks.

[36] Bernhardt, E.L., Hollingsworth, T.N., Chapin, F.S. (2011): Fire severity mediates climatedriven shifts in understorey community composition of black spruce stands of interior Alaska. - Journal of Vegetation Science 22(1): 32-44. 
[37] Bliss, L.C., Matveyeva, N.V. (1992): Circumpolar arctic vegetation. - In: Chapin III, F.S., Jefferies, R.L., Reynolds, J.F., Shaver, G.R., Svoboda, J. (eds.) Arctic ecosystems in a changing climate: an ecophysiological perspective, Academic Press, San Diego, California, USA.

[38] Bollinger, E.K., Harper, S.J., Barrett, G.W. (1990): Effects of seasonal drought on oldfield plant communities. - Am. Midland Nat. 125: 114-125.

[39] Bond, W.J., Midgley, G.F., Woodward, F.I. (2003): The importance of low atmospheric $\mathrm{CO}_{2}$ and fire in promoting the spread of grasslands and savannas. - Global Change Biology 9: 973-982.

[40] Bond, W.J., Woodward, F.I., Midgley, G.F. (2005): The global distribution of ecosystems in a world without fire. - New Phytol. 165: 525-538.

[41] Bouchard, M. (2001): The complex environmental challenge of the 21st century in Canada: Identification and understanding of the response of the environments facing global climatic changes. - Canadian Geographer-Geographe Canadien 45(1): 54-70.

[42] Bradley, B.A. (2009): Regional analysis of the impact of climate change on cheatgrass invasion shows potential risk and opportunity. - Global Change Biology 15: 196-208.

[43] Bradley, B.A., Oppenheimer, M., Wilcove, D.S. (2009): Climate change and plant invasions: restoration opportunities ahead? - Global Change Biol. 15: 1511-1521.

[44] Bradley, B.A. (2010): Assessing ecosystem threats from global and regional change: hierarchical modeling of risk to sagebrush ecosystems from climate change, land use and invasive species in Nevada, USA. - Ecography 33: 198-208.

[45] Breshears, D.D., Cobb, N.S., Rich, P.M., Price, K.P., Allen, C.D., Balice, R.G., Romme, W.H., Kastens, J.H., Floyd, M.L., Belnap, J., Anderson, J.J., Myers, O.B., Meyer, C.W. (2005): Regional vegetation die-off in response to global-change-type drought. - Proc. Nat. Acad. Sci. USA 102: 15144-15148.

[46] Breshears, D.D., Myers, O.B., Meyer, C.W., Barnes, F.J., Zou, C.B., Allen, C.D., McDowell, N.G., Pockman, W.T. (2009): Tree die-off in response to global change-type drought: mortality insights from a decade of plant water potential measurements. - Front. Ecol. Env. 7: 185-189.

[47] Bret-Harte, M.S., Shaver, G.R., Zoerner, J.P., Johnstone, J.F., Wagner, J.L., Chavez, A.S., Gunkelman, R.F., Lippert, S.C., Laundre, J.A. (2001): Developmental plasticity allows Betula nana to dominate tundra subjected to an altered environment. - Ecology 82: $18-32$.

[48] Bret-Harte, M.S., Shaver, G.R., Chapin, F.S. (2002): Primary and secondary stem growth in arctic shrubs: implications for community response to environmental change. - J. Ecol. 90: 251-267.

[49] Brock, M.A., Nielsen, D.L., Crosslé, K. (2005): Changes in biotic communities developing from freshwater wetland sediments under experimental salinity and water regimes. - Freshwater Biology 50: 1376-1390.

[50] Brooks, M.L. (2000): Competition between alien annual grasses and native annual plants in the Mojave Desert. - Am. Midl. Nat. 144: 92-108.

[51] Brooks, M.L. (2003): Effects of increased soil nitrogen on the dominance of alien annual plants in the Mojave Desert. - J. Appl. Ecol. 40: 344-353.

[52] Brown, J.H., Valone, T.J., Curtin, C.G. (1997): Reorganization of an arid ecosystem in response to recent climate change. - Proceedings of the National Academy of Science 94: 9729-9733.

[53] Brubaker, L.B., Garfinkel, H.L., Edwards, M.E. (1983): A Late-Wisconsin and Holocene vegetation history from the central Brooks Range: implications for Alaskan paleoecology. - Quat. Res. 20: 194-214.

[54] Buffington, L.C., Herbel, C.H. (1965): Vegetation changes on a semidesert grassland range from 1858 to 1963. - Ecol. Monogr. 35: 139-164.

[55] Burke, M.J.W., Grime, J.P. (1996): An experimental study of plant invasibility. - Ecology 77: 776-790. 
[56] Bush, M.A., Hooghiemstra, H. (2005): Tropical biotic responses to climate change. - In: Lovejoy, T.E., Hannah, L. (eds.) Climate change and biodiversity, Yale University Press, New Haven.

[57] Busing, R.T., Solomon, A.M., McKane, R.B., Burdick, C.A. (2007): Forest dynamics in Oregon landscapes: Evaluation and application of an individual-based model. Ecological Applications 17(7): 1967-1981.

[58] Calef, M.P., McGuire, A.D., Epstein, H.E., Rupp, T.S., Shugart, H.H. (2005): Analysis of vegetation distribution in Interior Alaska and sensitivity to climate change using a logistic regression approach. - Journal of Biogeography 32(5): 863-878.

[59] Camill, P. (1999): Peat accumulation and succession following permafrost thaw in the boreal peatlands of Manitoba, Canada. - Ecoscience 6: 592-602.

[60] Chapin, F.S. III, Shaver, G.R. (1985): Individualistic growth response of tundra plant species to environmental manipulations in the field. - Ecology 66: 564-576.

[61] Chapin, F.S. III, Shaver, G.R., Giblin, A.E., Nadelhoffer, K.J., Laundre, J.A. (1995): Responses of Arctic tundra to experimental and observed changes in climate. - Ecology 76(3): 694-711.

[62] Chapin, F.S. III, Shaver, G.R. (1996): Physiological and growth responses of arctic plants to a field experiment simulating climatic change. - Ecology 77: 822-840.

[63] Chapin, F.S. III, Starfield, A.M. (1997): Time lags and novel ecosystems in response to transient climatic change in arctic Alaska. - Climatic Change 35: 449-461.

[64] Chapin, III F.S., Zavaleta, E.S., Eviner, V.T., Naylor, R.L., Vitousek, P.M., Reynolds, H.L., Hooper, D.U., Lavorel, S., Sala, O.E., Hobbie, S.E., Mack, M.C., Díaz, S. (2000): Consequences of changing biodiversity. - Nature 405: 234-242.

[65] Chapin, F.S., Callaghan, T.V., Bergeron, Y., Fukuda, M., Johnstone, J.F., Juday, G., Zimov, S.A. (2004): Global change and the boreal forest: Thresholds, shifting states or gradual change? - AMBIO 33(6): 361-365.

[66] Chapin, F.S., Sturm, M., Serreze, M.C., McFadden, J.P., Key, J.R., Lloyd, A.H., McGuire, A.D., Rupp, T.S., Lynch, A.H., Schimel, J.P., Beringer, J., Chapman, W.L., Epstein, H.E., Euskirchen, E.S., Hinzman, L.D., Jia, G., Ping, C.L., Tape, K.D., Thompson, C.D.C., Walker, D.A., Welker, J.M. (2005): Role of land-surface changes in Arctic summer warming. - Science 310: 657-660.

[67] Chapman, W.L., Walsh, J.E. (1993): Recent variations of sea ice and air temperature in high latitudes. - BAMS 74 (1): 33-47.

[68] Charles, H., Dukes, J.S. (2009): Effects of warming and altered precipitation on plant and nutrient dynamics of a New England salt marsh. - Ecological Applications 19(7): 17581773.

[69] Chesson, P., Gebauer, R.L., Schwinning, S., Huntly, N., Wiegand, K., Ernest, M.S., Sher, A., Novoplansky, A., Weltzin, J.F. (2004): Resource pulses, species interactions, and diversity maintenance in arid and semiarid environments. - Oecologia 141: 236-253.

[70] Christensen, J.H., Hewitson, B., Busuioc, A., Chen, A., Gao, X., Held, I., Jones, R., Kolli, R.K., Kwon, W.-T., Laprise, R., Rueda, V.M., Mearns, L., Menéndez, C.G., Räisänen, J., Rinke, A., Sarr, A., Whetton, P. (2007): Regional climate projections (Chapter 11). - In: Solomon, S., Qin, D., Manning, M., Chen, Z., Marquis, M., Averyt, K.B., Tignor, M., Miller, H.L. (eds.) Climate change 2007: the Physical Science Basis. Contribution of Working Group I to the 4th Assessment Report of the Intergovernmental Panel on Climate Change, Cambridge University Press, Cambridge.

[71] Chuine, I., Beaubien, E.G. (2001): Phenology is a major determinant of tree species range. - Ecology Letters 4(5): 500-510.

[72] Churkina, G., Running, S.W. (1998): Contrasting climatic controls on the estimated productivity of global terrestrial biomes. - Ecosystems 1: 206-215.

[73] Classen, A.T., Norby, R.J., Campany, C.E., Sides, K.E., Weltzin, J.F. (2010): Climate Change Alters Seedling Emergence and Establishment in an Old-Field Ecosystem. PLoS ONE 5(10): e13476. 
[74] Clements, F.E. (1916): Plant succession: an analysis of the development of vegetation. Carnegie Institute, Washington, DC.

[75] Collevatti, R.G., Nabout, J.C., Diniz-Filho, J.A.F. (2011): Range shift and loss of genetic diversity under climate change in Caryocar brasiliense, a Neotropical tree species. - Tree Genetics \& Genomes 7: 1237-1247.

[76] Comita, L.S., Engelbrecht, B.M.J. (2009): Seasonal and spatial variation in water availability drive habitat associations in a tropical forest. - Ecology 90(10): 2755- 2765.

[77] Comstock, J.P., Ehleringer, J.R. (1992): Plant adaptation in the Great basin and Colorado Plateau. - Great Basin Naturalist 52: 195-215.

[78] Condit, R., Hubbell. S.P., Foster, R.B. (1995): Mortality rates of 205 neotropical tree and shrub species and the impact of a severe drought. - Ecol. Monogr. 65: 419-439.

[79] Condit, R. (1998): Ecological implications of changes in drought patterns: shifts in forest composition in Panama. - Clim. Change 39: 413-427.

[80] Crain, C.M., Silliman, B.R., Bertness, S.L., Bertness, M.D. (2004): Physical and biotic drivers of plant distribution across estuarine salinity gradients. - Ecology 85(9): 25392549.

[81] Crimmins, S.M., Dobrowski, S.Z., Greenberg, J.A., Abatzoglou, J.T., Mynsberge, A.R. (2011): Changes in Climatic Water Balance Drive Downhill Shifts in Plant Species' Optimum Elevations. - Science 331(6015): 324-327.

[82] Crumpacker, D.W., Box, E.O., Hardin, E.D. (2001): Implications of climatic warming for conservation of native trees and shrubs in Florida. - Conserv. Biol. 15: 1523-1739.

[83] Czóbel Sz., Szirmai O., Németh Z., Gyuricza Cs., Házi J., Tóth A., Schellenberger J., Vasa L., Károly P. (2012b): Short-term effects of grazing exclusion on net ecosystem $\mathrm{CO}_{2}$ exchange and net primary production in a Pannonian sandy grassland. Notula Bot Horti Agrobo. 40: 67-72.

[84] Czóbel Sz., Németh Z., Szirmai O., Gyuricza Cs., K. Penksza K. (2013): Short-term effects of extensive fertilization on community composition, and carbon uptake in a Pannonian loess grassland. Photosynthetica 51(4): 490-496.

[85] Dale, V.H., Joyce, L.A., McNulty, S., Neilson, R.P., Ayres, M.P., Flannigan, M.D., Hanson, P.J., Irland, L.C., Lugo, A.E., Peterson, C.J., Simberloff, D., Swanson, F.J., Stocks, B.J., Wotton, B.M. (2001): Climate change and forest disturbances. - BioScience 51: 723-734.

[86] Damschen, E.I., Harrison, S., Grace, J.B. (2010): Climate change effects on an endemicrich edaphic flora: resurveying Robert H. Whittaker's Siskiyou sites (Oregon, USA). Ecology 91(12): 3609-3619.

[87] Davis, M.B. (1981): Quaternary history and the stability of forest communities. - In: West, D.C., Shugart, H.H., Botkin, D.B. (eds.) Forest Succession, Springer, New York.

[88] Davis, M.B. (1986): Climatic instability, time lags, and community disequilibrium. - In: Diamond, J., Case, T.J. (eds.) Community Ecology, Harper \& Row, New York.

[89] Davis, M.B. (1989): Lags in vegetation response to greenhouse warming. - Climatic Change 15: 75- 82.

[90] Davis, S.M., Gunderson, L.H., Park, W.A., Richardson, J.R., Mattson, J.E. (1994): Landscape dimension, composition, and function in a changing Everglades ecosystem. In: Davis, S.M., Ogden, J.C. (eds.) Everglades: the ecosystem and its restoration, FL: St. Lucie Press, Boca Raton.

[91] Davis, M.A., Grime, J.P., Thompson, K. (2000): Fluctuating resources in plant communities: a general theory of invasibility. - J. Ecol. 88: 528-534.

[92] Davis, M.A., Pelsor, M. (2001): Experimental support for a resource-based mechanistic model of invasibility. - Ecol. Lett. 4: 421-428.

[93] Davis, M.B., Shaw, R.G. (2001): Range shifts and adaptive responses to quaternary climate change. - Science 292: 673-679.

[94] De Deyn, G.B., Cornelissen, J.H.C., Bardgett, R.D. (2008): Plant functional traits and soil carbon sequestration in contrasting biomes. - Ecology Letters 11: 516-531. 
[95] DeFalco, L.A., Bryla, D.R., Smith-Longozo, V., Nowak, R.S. (2003): Are Mojave Desert annual species equal? Resource acquisition and allocation for the invasive grass Bromus madritensis subsp. rubens (Poaceae) and two native species. - Am. J. Bot. 90: 10451053.

[96] Delissio, L.J., Primack, R.B. (2003): The impact of drought on the population dynamics of canopy-tree seedlings in an aseasonal Malaysian rain forest. - J. Trop. Ecol. 19: 489500 .

[97] Dermody, O., Weltzin, J.F., Engel, E.C., Allen, P., Norby, R.J. (2007): How do elevated $\left[\mathrm{CO}_{2}\right]$, warming, and reduced precipitation interact to affect soil moisture and LAI in an old field ecosystem? - Plant and Soil 301: 255-266.

[98] DeSantis, R.D., Hallgren, S.W., Lynch, T.B., Burton, J.A., Palmer, M.W. (2010): Longterm directional changes in upland Quercus forests throughout Oklahoma, USA. - J. Veg. Sci. 21: 606-615.

[99] DeSantis, R.D., Hallgren, S.W., Stahle, D.W. (2011): Drought and fire suppression lead to rapid forest composition change in a forest-prairie ecotone. - Forest Ecology and Management 261: 1833-1840.

[100] de Valpine, P., Harte, J. (2001a): Effects of warming on a montane meadow ecosystem: how species responses comprise the ecosystem response. - Ecology 82: 637-648.

[101] de Valpine, P., Harte, J. (2001b): Plant Responses to Experimental Warming in a Montane Meadow. - Ecology 82(3): 637-648.

[102] Diffenbaugh, N.S., Sloan, L.C., Snyder, M.A., Bell, J.L., Kaplan, J., Shafer, S.L., Bartlein, P.J. (2003): Vegetation sensitivity to global anthropogenic carbon dioxide emissions in a topographically complex region. - Global Biogeochemical Cycles 17(2) 1067

[103] Diniz-Filho, J.A.F., Nabout, J.C., Bini, L.M., Loyola, R.D., Rangel, T.F., Nogues-Bravo, D., Araújo, M.B. (2010): Ensemble forecasting shifts in climatic suitable areas for Tropidacris cristata (Orthoptera: Acridoidea: Romaleidae). - Insect Conservation and Diversity 3: 213-221.

[104] Dormann, C.F., Woodin, S.J. (2002): Climate change in the Arctic: using plant functional types in a meta-analysis of field experiments. - Funct. Ecol. 16: 4-17.

[105] Doyle, T.W., Girod, G.F., Books, M.A. (2003): Chapter 12: Modeling mangrove forest mitigation along the southwest coast of Florida under climate change. - In: Ning, Z.H., Turner, R.E., Doyle, T., Abdollahi, K.K. (lead authors) Integrated Assessment of the Climate Change Impacts on the Gulf Coast Region, Gulf Coast Climate Change Assessment Council (GCRCC) and Louisiana State University (LSU) Graphic Services.

[106] Dümig, A., Schad, P., Rumpel, C., Dignac, M., Kögel-Knabner, I. (2008): Araucaria forest expansion on grassland in the southern Brazilian highlands as revealed by ${ }^{14} \mathrm{C}$ and $\delta^{13} \mathrm{C}$ studies. - Geoderma 145: 143-147.

[107] Dyer, J.M. (1994): Implications of habitat fragmentation on climate change-induced forest migration. - Professional Geographer 46(4): 449-459.

[108] Dyer, J.M. (1994b): Land-use Pattern, Forest Migration, and Global Warming. Landscape and Urban Planning 29(2-3): 77-83.

[109] Easterling, D.R., Meehl, G.A., Parmesan, C., Chagnon, S.A., Karl, R.R., Mearns, L.O. (2000): Climate extremes: observation, modeling and impacts. - Science 289: 2068-2074.

[110] Edwards, M.E., Armbruster, W.S. (1989): A tundra-steppe transition on Kathul Mountain, Alaska, USA. - Arctic Alpine Res. 21: 296-304.

[111] Eeley, H.A.C., Lawes, M.J., Piper, S.E. (1999): The influence of climate change on the distribution of indigenous forest in KwaZulu-Natal, South Africa. - Journal of Biogeography 26: 595-617.

[112] Ehleringer, J.R., Cerling, T.E., Helliker, B.R. (1997): $C_{4}$ photosynthesis, atmospheric $\mathrm{CO}_{2}$ and climate. - Oecologia 112: 285-299. 
[113] Ehleringer, J.R., Schwinning, S., Gebauer, R. (1999): Water use in arid land ecosystems. - In: Press, M.C., Scholes, J.D., Barker, M.G. (eds.) Physiological Plant Ecology, Blackwell Science, Boston, USA.

[114] Ehleringer, J.R., Cerling, T.E., Flanagan, L.B. (2001): Global changes and the linkages between physiological ecology and ecosystem ecology. - In: Press, M., Huntly, N., Levin, S. (eds.) Ecology: Achievement and Challenge, Blackwell, Oxford.

[115] Ehman, J.L., Fan, W., Randolph, J.C., Southworth, J., Welch, N.T. (2002): An integrated GIS and modeling approach for assessing the transient response of forests of the southern Great Lakes Region to a doubled CO2 climate. - Forest Ecology and Management 155: $237-255$.

[116] Ehrenfeld, J.G. (1990): Dynamics and processes of barrier island vegetation. - Rev. Aquat. Sci. 2: 437-480.

[117] Elliott, G.P. (2011): Influences of 20th-century warming at the upper tree line contingent on local-scale interactions: evidence from a latitudinal gradient in the Rocky Mountains, USA. - Global Ecology and Biogeography 20(1): 46-57.

[118] Elsner, M.M., Cuo, L., Voisin, N., Deems, J.S., Hamlet, A.F., Vano, J.A., Mickelson, K.E.B., Lee, S.-Y., Lettenmaier, D.P. (2010): Implications of 21st century climate change for the hydrology of Washington State. - Climatic Change 102(1-2): 225-260.

[119] Epstein, H.E., Beringer, J., Gould, W.A., Lloyd, A.H., Thompson, C.D., Chapin, F.S., Michaelson, G.J., Ping, C.L., Rupp, T.S., Walker, D.A. (2004a): The nature of spatial transitions in the Arctic. - Journal of Biogeography 31(12): 1917-1933.

[120] Epstein, H.E., Calef, M.P., Walker, M.D., Chapin, F.S., Starfield, A.M. (2004b): Detecting changes in Arctic tundra plant communities in response to warming over decadal time scales. - Global Change Biol. 10: 1325-1334.

[121] Etkin, D., Paoli, G., Riseborough, D. (1998): Climate Change Impacts of Permafrost Engineering Design. - Environmental Adaptation Research Group, Environment Canada, Toronto.

[122] Euskirchen, E.S., McGuire, A.D., Chapin III, F.S., Yi, S., Thompson, C.C. (2009): Changes in vegetation in northern Alaska under scenarios of climate change, 2003-2100: implications for climate feedbacks. - Ecological Applications 19: 1022-1043.

[123] Fay, P.A., Carlisle, J.D., Danner, B.T., Lett, M.S., McCarron, J.K., Stewart, C., Knapp, A.K., Blair, J.M., Collins, S.L. (2002): Altered rainfall patterns, gas exchange, and growth in grasses and forbs. - International Journal of Plant Sciences 163: 549-557.

[124] Fay, P.A., Carlisle, J.D., Knapp, A.K., Blair, J.M., Collins, S.L. (2003): Productivity responses to altered rainfall patterns in a $\mathrm{C}_{4}$-dominated grassland. - Oecologia 137: 245251.

[125] Feeley, K.J., Silman, M.R., Bush, M.B., Farfan, W., Cabrera, K.G., Malhi, Y., Meir, P., Revilla, N.S., Quisiyupanqui, M.N.R., Saatchi, S. (2011): Upslope migration of Andean trees. - Journal of Biogeography 38(4): 783-791.

[126] Field, C., Daily, G., Davis, E., Gaines, S., Matson, P., Melack, J., Miller, N. (1999): Confronting change in California: ecological impacts on the Golden State. Report of the Union of Concerned Scientists and the Ecological Society of America. - UCS Publications, Cambridge, Massachusetts, USA.

[127] Fischlin, A., Bugmann, H., Gyalistras, D. (1995): Sensitivity of a forest ecosystem model to climate parametrization schemes. - Environ. Pollut. 87: 267-282.

[128] Flannigan, M.D., Bergeron, Y., Engelmark, O., Wotton, B.M. (1998): Future wildfire in circumboreal forests in relation to global warming. - Journal of Vegetation Science 9: 469-476.

[129] Flannigan, M.D., Stocks, B.J., Wotton, B.M. (2000): Climate change and forest fires. Sci. Total Environ. 262: 221-229.

[130] Flannigan, M.D., Logan, K.A., Amiro, B.D., Skinner, W.R., Stocks, B.J. (2005): Future area burned in Canada. - Clim. Change 72: 1-16. 
[131] Flantua, S.G.A., van Boxel, J.H., Hooghiemstra, H., van Smaalen, J. (2007): Application of GIS and logistic regression to fossil pollen data in modelling present and past spatial distribution of the Colombian savanna. - Clim. Dyn. 29: 697-712.

[132] Frelich, L.E., Reich, P.B. (1999): Neighborhood effects, disturbance severity, and community stability in forests. - Ecosystems 2: 151-166.

[133] Frelich, L.E., Reich, P.B. (2010): Will environmental changes reinforce the impact of global warming on the prairie-forest border of central North America? - Frontiers in Ecology and the Environment 8(7): 371-378.

[134] Fridley, J.D., Wright, J.P. (2012): Drivers of secondary succession rates across temperate latitudes of the Eastern USA: climate, soils, and species pools. - Oecologia 168: 10691077.

[135] Furley, P.A., Grace, J., Meir, P. (2006): Tropical savannas and seasonally dry forests: vegetation and environment. Special issue. - J. Biogeogr. 33: 164.

[136] Furley, P.A. (2007): Tropical savannas and associated forests: vegetation and plant ecology. - Prog. Phys. Geogr. 31: 203-211.

[137] Gaiser, E.E., Zafiris, A., Ruiz, P.L., Tobias, F.A.C., Ross, M.S. (2006): Tracking rates of ecotone migration due to salt-water encroachment using fossil mollusks in coastal South Florida. - Hydrobiologia 569: 237-257.

[138] Gao, Q., Reynolds, F.F. (2003): Historical shrub-grass transitions in the northern Chihuahuan Desert: modeling the effects of shifting rainfall seasonality and event size over a landscape gradient. - Global Change Biology 9: 1475-1793.

[139] Garamvölgyi, Á., Hufnagel, L. (2013): Impacts of climate change on vegetation distribution. No. 1: Climate change induced vegetation shifts in the Palearctic region. Applied Ecology and Environmental Research 11(1): 79-122.

[140] Gaylord, M.L., Kolb, T.E., Wallin, K.F., Wagner, M.R. (2007): Seasonal dynamics of tree growth, physiology, and resin defenses in a northern Arizona ponderosa pine forest. Can. J. For. Res. 37: 1173-1183.

[141] Giorgi, E, Shields, C.B., Bates, G.T. (1994): Regional climate change scenarios over the United States produced with a nested regional climate model: spatial and seasonal characteristics. - Journal of Climate 7: 375-399.

[142] Givnish, T.J., Volin, J.C., Owen, V.D., Volin, V.C., Muss, J.D., Glaser, P.H. (2008): Vegetation differentiation in the patterned landscape of the central Everglades: importance of local and landscape drivers. - Global Ecol. Biogeog. 17: 384-402.

[143] Gleason, H.A. (1926): The individualistic concept of the plant association. - Bull Torrey Bot. Club 53: 7-26.

[144] Gómez, F., Gaja, E., Reig, A. (1998): Vegetation and climatic changes in a city. - Ecol. Eng. 10: 355-360.

[145] Gómez-Mendoza, L., Arriaga, L. (2007): Modeling the effect of climate change on the distribution of oak and pine species of Mexico. - Conserv. Biol. 21: 1545-1555.

[146] Gorham, E. (1991): Northern peatlands: role in the carbon cycle and probable responses to climatic warming. - Ecological Applications 1: 182-195.

[147] Gosz, J.R., Sharpe, P.J.H. (1989): Broad-scale concepts for interactions of climate, topography, and biota at biome transitions. - Landscape Ecol. 3: 229-243.

[148] Gosz, J.R. (1992): Gradient analysis of ecological change in time and space: implications for forest management. - Ecol. Appl. 2: 248-261.

[149] Graetz, R.D., Walker, B.H., Walker, P.A. (1988): The consequence of climate change for seventy percent of Australia. - Natural Environment 399-420.

[150] Graham, R.L., Turner, M.G., Dale, V.H. (1990): How increasing atmospheric $\mathrm{CO}_{2}$ and climate change affects forests. - BioScience 40: 575-587.

[151] Graham, R.W. (1992): Late Pleistocene faunal changes as a guide to understanding effects of greenhouse warming on the mammalian fauna of North America. - In: Peters, R.L., Lovejoy, T.E. (eds.) Global warming and biological diversity, Yale University Press, New Haven, Connecticut, USA. 
[152] Grime, J.P., Willis, A.J., Hunt, R., Dunnett, N.P. (1994): Climate-vegetation relationships in the Bibury road verge experiments. - In: Leigh, R.A., Johnston, A.E. (eds.) Longterm Experiments in Agricultural and Ecological Sciences, CAB International, Wallingford.

[153] Grime, J.P, Brown, V.K., Thompson, K., Masters, G.J., Hillier, S.H., Clarke, I.P., Askew, A.P., Corker, D., Kielty, J.P. (2000): The response of two contrasting limestone grasslands to simulated climate change. - Science 289: 762-765.

[154] Groisman, P.Y., Karl, T.R., Easterling, D.R., Knight, R.W., Jamason, P.F., Hennessy, K.J., Suppiah, R., Page, C.M., Wibig, J., Fortuniak, K., Razuvaev, V.N., Douglas, A., Forland, E., Zhai, P. (1999): Changes in the probability of heavy precipitation: important indicators of climate change. - Clim. Change 42: 243-283.

[155] Groisman, P.Y., Knight, R.W., Karl, T.R., Easterling, D.R., Sun, B., Lawrimore, J.H. (2004): Contemporary changes of the hydrologic cycle over the contiguous United States: trends derived from in situ observations. - J. Hydrometeorol. 5: 64-85.

[156] Grundstein, A. (2009): Evaluation of climate change over the continental United States using a moisture index. - Climatic Change 93: 103-115.

[157] Gunderson, L.H., Loftus, W.F. (1993): The Everglades. - In: Martin, W.H., Boyce, S.G., Echternacht, A.C. (eds.) Biodiversity of the southeastern United States: lowland terrestrial communities, Joh Wiley \& Sons, Inc., New York.

[158] Gunderson, L.H. (1994): Vegetation of the Everglades: determinants of community composition. - In: Davis, S.M., Ogden, J.C. (eds.) Everglades: the ecosystem and its restoration, FL: St. Lucie Press, Boca Raton.

[159] Gutierrez, J.R., Whitford, W.G. (1987): Chihuahuan Desert annuals: importance of water and nitrogen. - Ecology 68: 2032-2045.

[160] Gutowski, W.J., Pan, Z., Anderson, C.J., Arritt, R.W., Otieno, E., Takle, E.S., Christensen, J.H., Christensen, O.B. (2000): What RCM data are available for California impacts modeling? California Energy Commission Workshop on Climate Change Scenarios for California, 12-13 June 2000. - California Energy Commission, Sacramento, California, USA.

[161] Hamann, A., Wang, T.L. (2006): Potential effects of climate change on ecosystem and tree species distribution in British Columbia. - Ecology 87: 2773-2786.

[162] Hansen, J., Lebedeff, S. (1987): Global trends of measured surface air temperature. Journal of Geophysical Research 92D: 13345-13372.

[163] Hansen, J.E., Sato, M., Ruedy, R., Lo, K., Lea, D.W., Medina-Elizade, M. (2006): Global temperature change. - Proc. Nat. Acad. Sci. USA 103: 14288-14293.

[164] Hanson, P.J., Weltzin, J.F. (2000): Drought disturbance from climate change: response of United States forests. - The Science of the Total Environment 262: 205-220.

[165] Harper, C.W., Blair, J.M., Fay, P.A., Knapp, A.K., Carlisle, J.D. (2005): Increased rainfall variability and reduced rainfall amount decreases soil $\mathrm{CO}_{2}$ flux in a grassland ecosystem. - Global Change Biol. 11: 322-334.

[166] Harte, J., Shaw, R. (1995): Shifting dominance within a montane vegetation community: results of a climate-warming experiment. - Science 267: 876-880.

[167] Harte, J., Torn, M.S., Chang, F.-R., Feifarek, B., Kinzig, A.P., Shaw, R., Shen, K. (1995): Global warming and soil microclimate: results from a meadow-warming experiment. Ecological Applications 5: 132-150.

[168] Harte, J., Saleska, S., Shih, T. (2006): Shifts in plant dominance control carbon-cycle responses to experimental warming and widespread drought. - Environmental Research Letters 1: 014001

[169] Hassol, S.J. (ed.) (2004): Arctic climate impact assessment: impacts of warming climate. - Cambridge University Press, Cambridge.

[170] Hauer, F.R., Baron, J.S., Campbell, D.H., Fausch, K.D., Hostetler, S.W., Leavesley, G.H., Leavitt, P.R., McKnight, D.M., Stanford, J.A. (1997): Assessment of climate change and freshwater ecosystems of the Rocky Mountains, USA and Canada. Hydrological Processes 11(8): 903-924. 
[171] Hayden, B.P., Dueser, R.D., Callahan, J.T., Shugart, H.H. (1991): Long-term research at Virginia Coast Reserve. - Bioscience 41: 310-318.

[172] He, H.S., Mladenoff, D.J., Crow, T.R. (1999): Linking an ecosystem model and a landscape model to study forest species response to climate warming. - Ecol. Model. 114: 213-233.

[173] He, F.L., Zhou, J., Zhu, H.T. (2003): Autologistic regression model for the distribution of vegetation. - Journal of Agricultural, Biological and Environmental Statistics 8(2): 205222.

[174] Heisler-White, J.L., Knapp, A.K., Kelly, E.F. (2008): Increasing precipitation event size increases aboveground net primary productivity in a semi-arid grassland. - Oecologia 158: 129-140.

[175] Hengeveld, H. (2000): Projections for Canada's climate future. Climate change digest CCD 00-01. Environment Canada. - Meteorological Service of Canada, Downsview.

[176] Hewitt, G.M. (1996): Some genetic consequences of ice ages, and their role in divergence and speciation. - Biol. J. Linn. Soc. 58: 247-276.

[177] Hewitt, G.M. (2000): The genetic legacy of the Quaternary ice ages. - Nature 405: 907913.

[178] Hickman, J.C. (ed.) (1993): The Jepson manual: higher plants of California. - University of California Press, Berkeley, California, USA.

[179] Higgins, P.A.T. (2007): Biodiversity loss under existing land use and climate change: an illustration using northern South America. - Global Ecology and Biogeography 16(2): 197-204.

[180] Hobbie, S.E., Chapin, F.S. III (1998): The response of tundra plant biomass, aboveground production, nitrogen, and $\mathrm{CO}_{2}$ flux to experimental warming. - Ecology 79(5): 15261544.

[181] Hoffmann, A.A., Willi, Y. (2008): Detecting genetic responses to environmental change. - Nature 9: 421-432.

[182] Hogenbirk, J.C., Wein, R.W. (1991): Fire and drought experiments in northern wetlands a climate change analog. - Canadian Journal of Botany-Revue Canadienne de Botanique 69(9): 1991-1997.

[183] Hogg, E.H., Hurdle, P.A. (1995): The aspen parkland in western Canada: a dry-climate analogue for the future boreal forest? - Soil Water Air Pollut. 82: 391-400.

[184] Holdridge, L. (1947): Determination of world plant formation from simple climatic data. - Science 105: 367-368.

[185] Hollister, R.D., Webber, P.J., Tweedie, C.E. (2005): The response of Alaskan arctic tundra to experimental warming: differences between short- and long-term responses. Global Change Biology 11: 525-536.

[186] Houghton, J.T., Meira Filho, L.G., Callander, B.A., Harris, N., Kattenberg, A., Maskell, K. (eds.) (1996): Climate change 1995. The science of climate change. - Cambridge University Press, Cambridge.

[187] Houghton, J.T., Ding, Y., Griggs, D.J., Noguer, M., van der Linden, P.J., Dai, X., Maskell, K., Johnson, C.A. (2001): Climate change 2001: the scientific basis. Contributions of Working Group 1 to the third assessment report of the Intergovernmental Panel on Climate Change. - Cambridge University Press, Cambridge.

[188] Howard, R. J., Mendelssohn, I.A. (2000): Structure and composition of oligohaline marsh plant communities exposed to salinity pulses. - Aquatic Botany 68: 142-164.

[189] Huntley, B. (1991): How plants respond to climate change: migration rates, individualism, and the consequences for plant communities. - Ann. Bot. (London) 67: 1522.

[190] Huston, M.A. (2004): Management strategies for plant invasions: manipulating productivity, disturbance, and competition. - Divers. Distrib. 10: 167-178. 
[191] Hutyra, L.R., Munger, J.W., Nobre, C.A., Saleska, S.R., Vieira, S.A., Wofsy, S.C. (2005): Climatic variability and vegetation vulnerability in Amazonia. - Geophysical Research Letters 32(24): L24712

[192] Huxman, T.E., Barron-Gafford, G., Gerst, K.L., Angert, A.L., Tyler, A.P., Venable, D.L. (2008): Photosynthetic resources-use efficiency and demographic variability in desert winter annual plants. - Ecology 89: 1554-1563.

[193] Ibanez, I., Clark, J.S., LaDeau, S., Hille Ris Lambers, J. (2007): Exploiting temporal variability to understand tree recruitment response to climate change. - Ecological Monographs 77(2): 163-177.

[194] Ibanez, I., Clark, J.S., Dietze, M.C. (2009): Estimating colonization potential of migrant tree species. - Global Change Biology 15(5): 1173-1188.

[195] IPCC (2001): Climate change 2001: the scientific basis. Contributions of working Group I to the Third Assessment Report of the Intergovernmental Panel on Climate Change. Cambridge University Press, Cambridge.

[196] IPCC (2007a): Climate change 2007: the physical science basis. - In: Solomon, S., Qin, D., Manning, M. (eds.) Contribution of working group I to the fourth assessment report of the intergovernmental panel on climate change, Cambridge University Press, Cambridge, United Kingdom and New York, USA.

[197] IPCC, Intergovernmental Panel on Climate Change (2007b): Climate Change 2007: The Synthesis Report. Cambridge University Press, Cambridge, UK.

[198] Iverson, L.R., Schwartz, M.W., Prasad, A.M. (2004): Potential colonization of newly available tree-species habitat under climate change: an analysis for five eastern US species. - Landscape Ecology 19(7): 787-799.

[199] Izaurralde, R.C., Thomson, A.M., Rosenberg, N.J., Brown, R.A. (2005): Climate change impacts for the conterminous USA: An integrated assessment. Part 6. Distribution and productivity of unmanaged ecosystems. - Climatic Change 69: 107-126.

[200] James, J.J., Caird, M.A., Drenovsky, R.E., Sheley, R.L. (2006): Influence of resource pulse and perennial neighbors on the establishment of an invasive annual grass in the Mojave Desert. - J. Arid Environ. 67: 528-534.

[201] Jason Todd, M., Muneepeerakul, R., Pumo, D., Azaele, S., Miralles-Wilhelm, F., Rinaldo, A., Rodriguez-Iturbe, I. (2010): Hydrological drivers of wetland vegetation community distribution within Everglades National Park, Florida. - Advances in Water Resources 33: 1279-1289.

[202] Jenerette, G.D., Harlan, S.L., Brazel, A., Jones, N., Larsen, L., Stefanov, W.L. (2007): Regional relationships between surface temperature, vegetation, and human settlement in a rapidly urbanizing ecosystem. - Landsc. Ecol. 22: 353-365.

[203] Johannessen, O.M., Bengtsson, L., Miles, M.W., Kuzmina, S.I., Semenov, V.A., Alekseev, G.V., Nagurnyi, A.P., Zakharov, V.F., Bobylev, L.P., Pettersson, L.H., Hasselmann, K., Cattle, A.P. (2004): Arctic climate change: observed and modelled temperature and sea-ice variability. - Tellus. Ser. A. 56: 328-341.

[204] Johnstone, J.F., Chapin III, F.S. (2006): Fire Interval Effects on Successional Trajectory in Boreal Forests of Northwest Canada. - Ecosystems 9: 268-277.

[205] Jonasson, S. (1992): Plant responses to fertilization and species removal in tundra related to community structure and clonality. - Oikos 63: 420-429.

[206] Jonasson, S., Michelsen, A., Schmidt, I.K., Nielsen, E.V. (1999): Responses in microbes and plants to changed temperature, nutrient, and light regimes in the arctic. - Ecology 80: $1828-1843$.

[207] Jonsdottir, I.S., Magnusson, B., Gudmundsson, J., Elmarsdottir, A., Hjartarson H. (2005): Variable sensitivity of plant communities in Iceland to experimental warming. - Global Change Biology 11: 553-563.

[208] Jorgenson, M.T., Racine, C.H., Walters, J.C., Osterkamp, T.E. (2001): Permafrost degradation and ecological changes associated with a warming climate in central Alaska. - Climatic Change 48: 551-579. 
[209] Juday, G.P., Solomon, R.C. (2000) Recent climatic and forest history of the Denali National Park and Preserve Headquarters Area, based on tree ring analysis. Report to the U.S. Geological Survey, Biological Research Division, Anchorage, AK.

[210] Jump, A.S., Peñuelas, J. (2005): Running to stand still: adaptation and the response of plants to rapid climate change. - Ecol. Lett. 8: 1010-1020.

[211] Jump, A.S., Mátyás, C., Peñuelas, J. (2009): The altitude-for-latitude disparity in the range retractions of woody species. - Trends Ecol. Evol. 24: 694-701.

[212] Kane, D.L., Hinzman, L.D., Woo, M., Everett, K.R. (1992): Arctic hydrology and climate change. - In: Chapin III, F.S., Jefferies, R.L., Reynolds, J.F., Shaver, G.R., Svoboda, J. (eds.) Arctic ecosystems in a changing climate: an ecophysiological perspective, Academic Press, San Diego, California, USA.

[213] Kaplan, J.O., Bigelow, N.H., Prentice, I.C., Harrison, S.P., Bartlein, P.J., Christensen, T.R., Cramer, W., Matveyeva, N.V., McGuire, A.D., Murray, D.F., Razzhivin, V.Y., Smith, B., Walker, D.A., Anderson, P.M., Andreev, A.A., Brubaker, L.B., Edwards, M.E., Lozhkin, A.V. (2003): Climate change and Arctic ecosystems: 2. Modeling, paleodata-model comparisons, and future projections. - J. Geophys. Res. Atmos. 108(D19): 8171.

[214] Kardol, P., Campany, C.E., Souza, L., Norby, R.J., Weltzin, J.F., Classen, A.T. (2010): Climate change effects on plant biomass alter dominance patterns and community evenness in an experimental old-field ecosystem. - Global Change Biology 16(10): 26762687

[215] Kasischke, E.S., Stocks, B.J. (eds.) (2000): Fire, climate change, and carbon cycling in the boreal forest. - Springer, Berlin, Heidelberg, New York.

[216] Kattenberg, A., Giorgi, F., Grassl, H., Meehl, G.A., Mitchell, J.F.B., Stouffer, R.J., Tokioka, T., Weaver, A.J., Wigley, T.M.L. (1996): Climate models-projections of future climate. - In: Houghton, J.T., Meira Filho, L.G., Callender, B.A., Harris, N., Kattenberg, A., Maskell, K. (eds.) Climate Change 1995-The Science of Climate Change: Contribution of Working Group I to the Second Assessment of the Intergovernmental Panel on Climate Change, Cambridge University Press, UK.

[217] Kaufman, D.S., Ager, T.A., Anderson, N.J., Anderson, P.M., Andrews, J.T., Bartlein, P.J., Brubaker, L.B., Coats, L.L., Cwynar, L.C., Duvall, M.L., Dyke, A.S., Edwards, M.E., Eisner, W.R., Gajewski, K., Geirsdóttir, A., Hu, F.S., Jennings, A.E., Kaplan, M.R., Kerwin, M.W., Lozhkin, A.V., MacDonald, G.M., Miller, G.H., Mock, C.J., Oswald, W.W., Otto-Bliesner, B.L., Porinchu, D.F., Rühland, K., Smol, J.P., Steig, E.J., Wolfe, B.B. (2004): Holocene thermal maximum in the western Arctic $\left(0-180^{\circ} \mathrm{W}\right)$. Quat. Sci. Rev. 23: 529-560.

[218] Keever, C. (1950): Causes of succession on old fields of the Piedmont, North Carolina. Ecol. Monogr. 20: 231-250.

[219] Kelly, A.E., Goulden, M.L. (2008): Rapid shifts in plant distribution with recent climate change. - Proceedings of the National Academy of Sciences of the United States of America 105(33): 11823-11826.

[220] Kerkhoff, A.J., Martens, S.N., Shore, G.A., Milne, B.T. (2004): Contingent effects of water balance variation on tree cover density in semiarid woodlands. - Global Ecology and Biogeography 13(3): 237-246.

[221] Kielland, K., Bryant, J.P., Ruess, R.W. (1997): Moose herbivory and carbon turnover of early successional stands in interior Alaska. - Oikos 80: 25-30.

[222] Kintisch, E. (2009): Projections of climate change go from bad to worse, scientists report. - Science 323: 1546-1547.

[223] Kittel, T.G.F., Baker, B.B., Higgins, J.V., Haney, J.C. (2011): Climate vulnerability of ecosystems and landscapes on Alaska's North Slope. - Reg. Environ. Change 11 (Suppl. 1): S249-S264.

[224] Knapp, A.K., Smith, M.D. (2001): Variation among biomes in temporal dynamics of aboveground primary production. - Science 291: 481-484. 
[225] Knapp, A.K., Fay, P.A., Blair, J.M., Collins, S.L., Smith, M.D., Carlisle, J.D., Harper, C.W., Danner, B.T., Lett, M.S., McCarron, J.K. (2002): Rainfall variability, carbon cycling, and plant species diversity in a mesic grassland. - Science 298: 2202-2205.

[226] Koepke, D.F., Kolb, T.E., Adams, H.D. (2010): Variation in woody plant mortality and dieback from severe drought among soils, plant groups, and species within a northern Arizona ecotone. - Oecologia 163: 1079-1090.

[227] Körner, C., Larcher, W. (1988): Plant life in cold climates. - Symposium of the Society of Experimental Biology 42: 25-57.

[228] Kupfer, J.A., Cairns, D.M. (1996): The suitability of montane ecotones as indicators of global climatic change. - Progress in Physical Geography 20(3): 253-272.

[229] Lafleur, B., Pare, D., Munson, A.D., Bergeron, Y. (2010): Response of northeastern North American forests to climate change: Will soil conditions constrain tree species migration? - Environmental Reviews 18: 279-289.

[230] Lantz, T.C., Kokelj, S.V. (2008): Increasing rates of retrogressive thaw slump activity in the Mackenzie Delta region, N.W.T., Canada. - Geophys. Res. Lett. 35: L06502.

[231] Lantz, T.C., Gergel, S.E., Kokelj, S.V. (2010): Spatial Heterogeneity in the Shrub Tundra Ecotone in the Mackenzie Delta Region, Northwest Territories: Implications for Arctic Environmental Change. - Ecosystems 13: 194-204.

[232] Larsen, J.A. (1965): The vegetation of Ennadai Lake area, N.W.T.: studies in subarctic and arctic bioclimatology. - Ecol. Monog. 35: 37-59.

[233] Larsen, C.P.S. (1997): Spatial and temporal variations in boreal forest fire frequency in northern Alberta. - J. Biogeog. 24: 663-673.

[234] Lashof, D.A., Ahuja, D.R. (1990): Relative contributions of greenhouse gas emissions to global warming. - Nature 344: 529-531.

[235] Lassiter, R.R., Box, E.O., Wiegert, R.G., Johnston, J.M., Bergengren, J., Suarez, L.A. (2000): Vulnerability of ecosystems of the mid-Atlantic region, USA, to climate change. Environmental Toxicology and Chemistry 19(4): 1153-1160.

[236] Lawrence, D.M., Swenson, S.C. (2011): Permafrost response to increasing Arctic shrub abundance depends on the relative influence of shrubs on local soil cooling versus largescale climate warming. - Environmental Research Letters 6(4): 045504

[237] Leck, M.A. (1989): Wetland seed banks. - In: Leck, M.A., Parker, V.T., Simpson, R.L. (eds.) Ecology of soil seed banks, Academic Press, New York.

[238] Leemans, R. (1991): Sensitivity analysis of a forest succession model. - Ecol. Model. 53: $247-262$.

[239] Le Houerou, H.N., Bingham, R.L., Skerbek, W. (1988): Relationship between the variability of primary production and the variability of annual precipitation in world arid lands. - J. Arid Environ. 15: 1-8.

[240] Lemieux, C.J., Scott, D.J. (2005): Climate change, biodiversity conservation and protected area planning in Canada. - Canadian Geographer-Geographe Canadien 49(4): 384-399.

[241] Lenihan, J., Neilson, R. (1995): Canadian vegetation sensitivity to projected climatic change at three organizational levels. - Clim. Change 30: 27-56.

[242] Lenihan, J.M., Drapek, R., Bachelet, D., Neilson, R.P. (2003): Climate Change Effects on Vegetation Distribution, Carbon, and Fire in California. - Ecological Applications 13 (6): $1667-1681$.

[243] Lenihan, J.M., Bachelet, D., Neilson, R.P., Drapek, R. (2008a): Simulated response of conterminous United States ecosystems to climate change at different levels of fire suppression, $\mathrm{CO}_{2}$ emission rate, and growth response to $\mathrm{CO}_{2}$. - Global and Planetary Change 64: 16-25.

[244] Lenihan, J.M., Bachelet, D., Neilson, R.P., Drapek, R. (2008b): Response of vegetation distribution, ecosystem productivity, and fire to climate change scenarios for California. Climatic Change 87 (Suppl 1): S215-S230. 
[245] Lenoir, J., Gégout, J.C., Marquet, P.A., de Ruffray, P., Brisse, H. (2008): A significant upward shift in plant species optimum elevation during the 20th century. - Science 320: $1768-1771$.

[246] Leverenz, J.W., Lev, D.J. (1987): Effects of carbon dioxide induced climate changes on the natural ranges of six major commercial tree species in the western United States. - In: Shands, W.E., Hoffman, J.S. (eds.) The greenhouse effect, climate change and US forests, The Conservation Foundation, Washington, DC.

[247] Lindner, M., Bugmann, H., Lasch, P., Flechsig, M., Cramer, W. (1997): Regional impacts of climatic change on forests in the state of Brandenburg, Germany. - Agric. For. Meteorol. 84: 123-135.

[248] Lishawa, S.C., Albert, D.A., Tuchman, N.C. (2010): Water Level Decline Promotes Typha X glauca Establishment and Vegetation Change in Great Lakes Coastal Wetlands. - Wetlands 30(6): 1085-1096.

[249] Littell, J.S., Oneil, E.E., McKenzie, D., Hicke, J.A., Lutz, J.A., Norheim, R.A., Elsner, M.M. (2010): Forest ecosystems, disturbance, and climatic change in Washington State, USA. - Climatic Change 102: 129-158.

[250] Lloyd, A.H., Yoshikawa, K., Fastie, C.L., Hinzman, L., Fraver, M. (2003): Effects of permafrost degradation on woody vegetation at arctic treeline on the Seward Peninsula, Alaska. - Permafr. Periglac. Process 14: 93-101.

[251] Loehle, C. (1996): Do simulations predict unrealistic dieback? - J. For. 94: 13-15.

[252] Loehle, C., LeBlanc, D. (1996): Model-based assessments of climate change effects on forests: a critical review. - Ecol. Model. 90: 1-31.

[253] Loehle, C. (1998): Height growth rate tradeoffs determine northern and southern range limits for trees. - J. Biogeogr. 25: 735-742.

[254] Lu, Q.Q., Lund, R., Seymour, L. (2005): An update of U.S. temperature trends. - J. Climate 18(22): 4906-4914.

[255] Lund, R.B., Seymour, P.L., Kafadar, K. (2001): Temperature trends in the United States. - Environmetrics 12: 673-690.

[256] Luo, Z.K., Sun, O.J., Ge, Q.S., Xu, W.T., Zheng, J.Y. (2007): Phenological responses of plants to climate change in an urban environment. - Ecol. Res. 22: 507-514.

[257] Lutz, J.A., van Wagtendonk, J.W., Franklin, J.F. (2010): Climatic water deficit, tree species ranges, and climate change in Yosemite National Park. - Journal of Biogeography 37(5): 936-950.

[258] Mack, M.C., Schuur, E.A.G., Bret-Harte, M.S., Shaver, G.R., Chapin, F.S. (2004): Ecosystem carbon storage in arctic tundra reduced by long-term nutrient fertilization. Nature 431: 440-443.

[259] Malanson, G.P., Westman, W.E. (1991): Modeling interactive effects of climate change, air-pollution, and fire on a California shrubland. - Climatic Change 18(4): 363-376.

[260] Malanson, G.P. (1993): Comment on modeling ecological response to climatic change. Clim. Change 23: 95-109.

[261] Malanson, G.P. (2001): Complex responses to global change at alpine treeline. - Physical Geography 22(4): 333-342.

[262] Malatinszky Á, Ádám Sz, S.-Falusi E, Saláta D, Penksza K (2013a): Planning management adapted to climate change effects in terrestrial wetlands and grasslands. International Journal of Global Warming 5(3): 311-325.

[263] Malatinszky Á., Ádám Sz., Falusi E., Saláta D., Penksza K. (2013b): Climate Change Related Land User Problems in Protected Wetlands: a Study in a Seriously Affected Hungarian Area. Climatic Change 118: 671-683.

[264] Malcolm, J., Markham, A. (1996): Ecosystem resilience, biodiversity and climate change: setting limits. - Parks 6: 38-49. 
[265] Martinelli, L.A., Pessenda, L.C.R., Espinoza, E. (1996): Carbon-13 depth variation in soil of Brazil and relations with climate changes during the Quaternary. - Oecologia 106: 376-381.

[266] Mátyás, C. (2010): Forecasts needed for retreating forests. - Nature 464: 1271.

[267] Maxwell, B. (1992): Arctic climate: potential for change under global warming. - In: Chapin III, F.S., Jefferies, R.L., Reynolds, J.F., Shaver, G.R., Svoboda, J. (eds.) Arctic ecosystems in a changing climate: an ecophysiological perspective, Academic Press, San Diego, California, USA.

[268] McGuire, A.D., Chapin, F.S., Walsh, J.E., Wirth, C. (2006): Integrated regional changes in Arctic climate feedbacks: implications for the global climate system. - Ann. Rev. Environ. Resour. 31: 61-91.

[269] Meiners, S.J., Pickett, S.T.A., Cadenasso, M.L. (2002): Exotic plant invasions over 40 years of old field successions: community patterns and associations. - Ecography 25: 215-223.

[270] Melillo, J.M., Borchers, J., Chaney, J., Fisher, H., Fox, S., Haxeltine, A., Janetos, A., Kicklighter, D.W., Kittel, T.G.F., McGuire, A.D., McKeown, R., Neilson, R., Nemani, R., Ojima, D.S., Painter, T., Pan, Y., Parton, W.J., Pierce, L., Pitelka, L., Prentice, C., Rizzo, B., Rosenbloom, N.A., Running, S., Schimel, D.S., Sitch, S., Smith, T., Woodward, I. (1995): Vegetation Ecosystem Modeling and Analysis Project - Comparing Biogeography and Biogeochemistry Models in a Continental-Scale Study of Terrestrial Ecosystem Responses to Climate-Change and $\mathrm{CO}_{2}$ Doubling. - Global Biogeochemical Cycles 9(4): 407-437.

[271] Mellinger, M.V., McNaughton, S.J. (1975): Structure and function of successional vascular plant communities in central New York. - Ecol. Monogr. 45: 161-182.

[272] Michener, W.K., Blood, E.R., Bildstein, K.L., Brinson, M.M., Gardner, L.R. (1997): Climate change, hurricanes and tropical storms, and rising sea level in coastal wetlands. Ecological Applications 7: 770-801.

[273] Middleton, B.A. (1999a): Succession and herbivory in monsoonal wetlands. - Wetland Ecology and Management 6: 189-202.

[274] Middleton, B.A. (1999b): Wetland restoration, flood pulsing and disturbance dynamics. Wiley, New York.

[275] Middleton, B.A. (2003): Soil seed banks and the potential restoration of forested wetlands after farming. - J. Appl. Ecol. 40: 1025-1034.

[276] Middleton, B.A., McKee, K.L. (2004): Use of a latitudinal gradient in bald cypress production to examine physiological controls on biotic boundaries and potential responses to environmental change. - Glob. Ecol. Biogeogr. 13: 247-258.

[277] Middleton, B.A., Wu, X.B. (2008): Landscape spatial distribution and anthropogenic change of seed banks in forested wetlands in the northern Mississippi River Alluvial Valley. - Ecoscience 15: 231-240.

[278] Middleton, B.A. (2009a): Regeneration of coastal marsh vegetation impacted by Hurricanes Katrina and Rita. - Wetlands 29: 54-65.

[279] Middleton, B.A. (2009b): Effects of Hurricane Katrina on the forest structure of baldcypress swamps of the Gulf Coast. - Wetlands 29: 80-87.

[280] Middleton, B.A. (2009c): Effects of Hurricane Katrina on tree regeneration in baldcypress swamps of the Gulf Coast. - Wetlands 29: 135-141.

[281] Middleton, B.A. (2009d): Regeneration potential of baldcypress (Taxodium distichum) swamps and climate change. - Plant Ecology 202: 257-274.

[282] Middleton, B.A., McKee, K.L. (2012): Can elevated $\mathrm{CO}_{2}$ modify regeneration from seed banks of floating freshwater marshes subjected to rising sea-level? - Hydrobiologia 683: 123-133.

[283] Mitsch, W.J., Gosselink, J.G. (2000): Wetlands. Van Nostrand Reinhold, New York, New York.

[284] Mitsch, W.J., Gosselink, J.G. (2007): Wetlands. NJ: Wiley, Hoboken. 
[285] Mohan, J.E., Clark, J.S., Schlesinger, W.H. (2007): Long-term $\mathrm{CO}_{2}$ enrichment of a forest ecosystem: Implications for forest regeneration and succession. - Ecological Applications 17: 1198-1212.

[286] Monaco, T.A., Johnson, D.A., Norton, J.M., Jones, T.A., Connors, K.J., Norton, J.B., Redinbaugh, M.B. (2003): Contrasting responses of Intermountain West grasses to soil nitrogen. - J. Range Manage. 56: 289-290.

[287] Monger, H.C. (2003): Millennial-scale climate variability and ecosystem response at the Jornada LTER site. - In: Greenland, D., Goodin, D.G., Smith, R.C. (eds.) Climate Variability and Ecosystem Response at Long-Term Ecological Research Sites, Oxford University Press, London.

[288] Morin, X., Chuine, I. (2005): Sensitivity analysis of the tree distribution model PHENOFIT to climatic input characteristics: implications for climate impact assessment. - Global Change Biology 11(9): 1493-1503.

[289] Morin, X., Viner, D., Chuine, I. (2008): Tree species range shifts at a continental scale: new predictive insights from a process-based model. - Journal of Ecology 96(4): 784794.

[290] Mote, P.W., Jr. Salathé, E.P. (2010): Future climate in the Pacific Northwest. - Climatic Change 102: 29-50.

[291] Mueller, R.C., Scudder, C.M., Porter, M.E., Trotter, R.T., Gehring, C.A., Whitham, T.G. (2005): Differential tree mortality in response to severe drought: evidence for long-term vegetation shifts. - Journal of Ecology 93(6): 1085-1093.

[292] Myers, N. (1995): Environmental unknowns. - Science 269: 358-360.

[293] National Assessment Synthesis Team (NAST) (2000): Climate Change Impacts on the United States: Potential Consequences of Climate Variability and Change. US Global Change Research Program, Washington, DC. - Cambridge University Press, New York, USA.

[294] Neilson, R.P., King, G.A., DeVelice, R.L., Lenihan, J., Marks, D., Dolph, J., Campbell, B., Glick, G. (1989): Sensitivity of Ecological Landscapes and Regions to Global Climate Change. - US Environmental Protection Agency, Environmental Research Laboratory, Corvallis, OR.

[295] Neilson, R.P., King, G.A., Koerper, G. (1992): Toward a Rule-Based Biome Model. Landscape Ecology 7(1): 27-43.

[296] Neilson, R.P., Drapek, R.J. (1998): Potentially complex biosphere responses to transient global warming. - Global Change Biol. 4: 505-521.

[297] Nippert, J.B., Knapp, A.K., Briggs, J.M. (2006): Intra-annual rainfall variability and grassland productivity: can the past predict the future? - Plant Ecol. 184: 65-74.

[298] Notaro, M., Vavrus, S., Liu, Z.Y. (2007): Global vegetation and climate change due to future increases in $\mathrm{CO} 2$ as projected by a fully coupled model with dynamic vegetation. J. Clim. 20: 70-90.

[299] Novoplansky, A., Goldberg, D.A. (2001): Effects of water pulsing on individual performance and competitive hierarchies in plants. - J. Veg. Sci. 12: 199-208.

[300] Nowacki, G.J., Abrams, M.D. (2008): The demise of fire and "mesophication" of forests in the eastern United States. - Bioscience 58: 123-138.

[301] Odum, W.E., McIvor, C.C., Smith, T.J. (1982): The ecology of the mangroves of South Florida: a community profile. - US Fish and Wildlife Service FWS/OBS-81/24.

[302] Odum, W.E., Hoover, J.K. (1988): A comparison of vascular plant communities in tidal freshwater and salt-water marshes. - In: Hook, D.D. et al. (eds.) The ecology and management of wetlands, Croom Helm, London.

[303] Odum, W.E., McIvor, C.C. (1990): Mangroves. - In: Myers, R.L., Ewel, J.J. (eds.) Ecosystems of Florida, The University of Central Florida Press, Orlando, FL, USA.

[304] Oechel, W.C., Cowles, S., Grulke, N., Hastings, S.J., Lawrence, W., Prudhomme, T., Riechers, G., Strain, B., Tissue, D., Vourlitis, G. (1994): Transient nature of $\mathrm{CO}_{2}$ fertilization in arctic tundra. -Nature 371: 500-503. 
[305] Ojima, D.S., Dirks, B.O.M., Glenn, E.P., Owensby, C.E., Scurlock, J.O. (1993): Assessment of $\mathrm{C}$ budget for grasslands and drylands of the world. - Water, Air, and Soil Pollution 70: 95-109.

[306] Olthof, I., Latifovic, R. (2007): Short-term response of arctic vegetation NDVI to temperature anomalies. - International Journal of Remote Sensing 28(21): 4823-4840.

[307] O’Neill, E.G., Johnson, D.W., Ledford, J., Todd, D.E. (2003): Acute seasonal drought does not permanently alter mass loss and nitrogen dynamics during decomposition of red maple (Acer rubrum L.) litter. - Global Change Biology 9: 117-123.

[308] Oosting, H.J. (1942): An ecological analysis of the plant communities of Piedmont, North Carolina. - Am. Mid. Nat. 28: 1-126.

[309] Osterkamp, T.E., Viereck, L., Shur, Y., Jorgenson, M.T., Racine, C., Doyle, A., Boone, R.D. (2000): Observations of thermokarst and its impact on boreal forests in Alaska, USA. - Arctic, Antarctic, and Alpine Research 32: 303-315.

[310] Oswald, W.W., Brubaker, L.B., Hu, F.S., Kling, G.W. (2003): Holocene pollen records from the central Arctic Foothills, northern Alaska: testing the role of substrate in the response of tundra to climate change. - J. Ecol. 91(6): 1034-1048.

[311] Overpeck, J.T., Bartlein, P.J., Webb, T. (1991): Potential magnitude of future vegetation change in eastern North-America - comparisons with the past. - Science 254(5032): 692695.

[312] Pake, C.E., Venable, D.L. (1995): Is coexistence of Sonoran Desert annuals mediated by temporal variability in reproductive success? - Ecology 76: 246-261.

[313] Palmer, A.R., Van Rooyen, A.F. (1998): Detecting vegetation change in the southern Kalahari using Landsat TM data. - J. Arid Environ. 3: 143-153.

[314] Parmesan, C. (2006): Ecological and evolutionary responses to recent climate change. Annu. Rev. Ecol. Evol. Syst. 37: 637-669.

[315] Parsons, A.N., Welker, J.M., Wookey, P.A., Press, M.C., Callaghan, T.V., Lee, J.A. (1994): Growth responses of 4 Sub-Arctic dwarf shrubs to simulated environmental change. - Journal of Ecology 82: 307-318.

[316] Parton, W.J., Lauenroth, W.K., Smith, F.M. (1981): Water loss from a shortgrass steppe. - Agric. Meteorol. 24: 97-109.

[317] Paruelo, J.M., Lauenroth, W.K. (1996): Relative abundance of plant functional types in grasslands and shrublands of North America. - Ecological Applications 6: 1212-1224.

[318] Pastor, J., Post, W.M. (1988): Response of northern forests to CO2-induced climate change. - Nature 334: 55-58.

[319] Payette, S., Gagnon, R. (1985): Late Holocene deforestation and tree regeneration in the forest-tundra of Quebec. - Nature 313: 570-572.

[320] Payette, S., Fortin, M.-J., Gamache, I. (2001): The subarctic forest-tundra: the structure of a biome in a changing climate. - Bio-Science 51: 709-718.

[321] Pendall, E., Bridgham, S., Hanson, P.J., Hungate, B., Kicklighter, D.W., Johnson, D.W.; Law, B.E., Luo, Y., Megonigal, J. P., Olsrud, M., Ryan, M.G., Wan, S. (2004): Belowground process responses to elevated $\mathrm{CO}_{2}$ and temperature: a discussion of observations, measurement methods, and models. - New Phytologist 162: 311-322.

[322] Penksza K., Szentes Sz., Házi J., Tasi J., Bartha S., Malatinszky Á. (2009): Grassland management and nature conservation in natural grasslands of the Balaton Uplands National Park, Hungary. - Grassland Science in Europe 15: 512-515.

[323] Penksza K., Kiss T., Herczeg E., Nagy A., Malatinszky Á. (2011): Anthropogenic impacts and management of natural grasslands on kurgans. - BAR International Series 22: 329-338.

[324] Penksza K., Házi J., Tóth A., Wichmann B., Pajor F., Gyuricza Cs., Póti P., Szentes Sz. (2013): Eltérő hasznosítású szürkemarha legelő szezonális táplálóanyag tartalom alakulás, fajdiverzitás változása és ennek hatása a biomassza mennyiségére és összetételére nedves pannon gyepekben. - Növénytermelés 62(1): 73-94. 
[325] Pennington, R.T., Lavin, M., Prado, D.E., Pendry, C.A., Pell, S., Butterworth, C.A. (2004): Historical climate change and speciation: neotropical seasonally dry forest plants show patterns of both Tertiary and Quaternary diversification. - Philos. Trans. R. Soc. 359: 515-538.

[326] Pennington, T., Lewis, G., Ratter, J.A. (2006): Neotropical savannas and seasonally dry forests: plant diversity, biogeography, and conservation. - Systematics association, special volume series 69. CRC-Taylor and Francis, Boca Raton.

[327] Perfors, T., Harte, J., Alter, S. (2003): Enhanced growth of sagebrush (Artemisia tridentata) in response to manipulated ecosystem warming. - Global Change Biology 9(5): 736-742.

[328] Peters, D.P.C. (2002): Plant species dominance at a grassland-shrubland ecotone: an individual-based gap dynamics model of herbaceous and woody species. - Ecological Modelling 152: 5-32.

[329] Peters, D.P.C., Yao, J., Sala, O.E., Anderson, J.P. (2012): Directional climate change and potential reversal of desertification in arid and semiarid ecosystems. - Global Change Biology 18(1): 151-163.

[330] Platt, W.J., Connell, J.J. (2003): Natural disturbances and directional replacement of species. - Ecological Monographs 73: 507-522.

[331] Polley, H.W., Jin, V.L., Fay, P.A. (2012): $\mathrm{CO}_{2}$-caused change in plant species composition rivals the shift in vegetation between mid-grass and tallgrass prairies. Global Change Biology 18(2): 700-710.

[332] Potter, C. (2004): Predicting climate change effects on vegetation, soil thermal dynamics, and carbon cycling in ecosystems of interior Alaska. - Ecological Modelling 175: 1-24.

[333] Prentice, I.C., Sykes, M.T., Cramer, W. (1993): A simulation model for the transient effects of climate change on forest landscapes. - Ecol. Model. 65: 51-70.

[334] Pucko, C., Beckage, B., Perkins, T., Keeton, W.S. (2011): Species shifts in response to climate change: Individual or shared responses? - Journal of the Torrey Botanical Society 138(2): 156-176.

[335] Puyravaud, J.P., Pascal, J.P., Dufour, C. (1994): Ecotone structure as an indicator of changing forest-savanna boundaries (Linganamakki Region, southern India). - J. Biogeogr. 21: 581-593.

[336] Randolph, J.C., Lee, J.K. (1994): Effects of climate change on forests of the Eastern United States. - Geocarto Int. 1: 15-30.

[337] Rao, L.E., Allen, E.B. (2010): Combined effects of precipitation and nitrogen deposition on native and invasive winter annual production in California deserts. - Oecologia 162: $1035-1046$.

[338] Ravenscroft, C., Scheller, R.M., Mladenoff, D.J., White, M.A. (2010): Forest restoration in a mixed-ownership landscape under climate change. - Ecological Applications 20(2): $327-346$.

[339] Rehfeldt, G.E., Tchebakova, N.M., Parfenova, Y.I., Wykoff, W.R., Kuzmina, N.A., Milyutin, L.I. (2002): Intraspecific responses to climate in Pinus sylvestris. - Global Change Biology 8: 912-929.

[340] Rehfeldt, G.E., Crokston, N.L., Warwell, M.V., Evans, J.S. (2006): Empirical analysis of plant-climate relationships for the western United States. - International Journal of Plant Sciences 167(6): 1123-1150.

[341] Rice, E.L., Penfound, W.T. (1959): The upland forests of Oklahoma. - Ecology 40: 593608.

[342] Rippstein, G., Escobar, G., Motta, F. (2001): Agroecologi'a y biodiversidad de las Sabanas en Llanos orientales de Colombia. - Cali: Centro internacional de Agricultura Tropical (CIAT). Publication CIAT No. 322

[343] Risser, P.G. (1995): The status of the science examining ecotones. - Bioscience 45: 318325. 
[344] Robinson, S.C., Ketchledge, E.H., Fitzgerald, B.T., Raynal, D.J., Kimmerer, R.W. (2010): A 23-year assessment of vegetation composition and change in the Adirondack alpine zone, New York State. - Rhodora 112(952): 355-377.

[345] Roland, C. (1999): Summary and analysis of vegetation data from Denali long term ecological monitoring program permanent plots, 1992-1998. - Denali National Park and Preserve, National Park Service, U.S. Department of the Interior, Denali National Park, AK.

[346] Romme, W.H., Turner, M.G. (1991): Implications of Global Climate Change for Biogeographic Patterns in the Greater Yellowstone Ecosystem. - Conservation Biology 5(3): 373-386.

[347] Romme, W.H., Turner, M.G., Wallace, L.L., Walker, J.S. (1995): Aspen, elk and fire in Northern Yellowstone National Park. - Ecology 76: 2097-2106.

[348] Rosenzweig, M.L. (1968): Net primary productivity of terrestrial communities: predictions from climatological data. - Am. Nat. 102: 67-74.

[349] Ross, M.S., Reed, D.L., Sah, J.P., Ruiz, P.L., Lewin, M.T. (2003): Vegetation: environment relationships and water management in Shark Slough, Everglades National Park. - Wetlands Ecol. Manag. 11: 291-303.

[350] Rupp, T.S., Starfield, A.M., Chapin, F.S. III (2000): A frame-based spatially explicit model of subarctic vegetation response to climatic change: comparison with a point model. - Landscape Ecology 15: 383-400.

[351] Rupp, T.S., Starfield, A.M., Chapin III, F.S., Duffy, P. (2002): Modeling the impact of black spruce on the fire regime of Alaska boreal forest. - Climatic Change 55: 213-233.

[352] Sala, O.E., Lauenroth, W.K., Parton, W.J. (1992): Long-term soil water dynamics in the shortgrass steppe. - Ecology 73: 1175-1181.

[353] Salazar, L.F., Nobre, C.A., Oyama, M.D. (2007): Climate change consequences on the distribution in tropical South America. - Geophysical Research Letters 34: 1-6.

[354] Salazar, L.F., Nobre, C.A. (2010): Climate change and thresholds of biome shifts in Amazonia. - Geophysical Research Letters 37: L17706

[355] Saveedra, F., Inouye, D., Price, M., Harte, J. (2003): Changes in flowering and abundance of Delphinium nuttallianum (Ranunculaceae) in response to a subalpine climate warming experiment. - Global Change Biology 9(6): 885-894.

[356] Scheffer, M., Carpenter, S., Foley, J.A., Folkes, C., Walker, B. (2001): Catastrophic shifts in ecosystems. - Nature 413: 591-596.

[357] Scheller, R.M., Mladenoff, D.J. (2005): A spatially interactive simulation of climate change, harvesting, wind, and tree species migration and projected changes to forest composition and biomass in northern Wisconsin, USA. - Global Change Biology 11(2): 307-321.

[358] Schenk, H.J. (1996): Modeling the effects of temperature on growth and persistence of tree species: a critical review of tree population models. - Ecol. Model. 92: 1-32.

[359] Schneider, R.R., Hamann, A., Farr, D., Wang, X.L., Boutin, S. (2009): Potential effects of climate change on ecosystem distribution in Alberta. - Canadian Journal of Forest Research-Revue Canadienne de Recherche Forestiere 39(5): 1001-1010.

[360] Schrag, A.M., Bunn, A.G., Graumlich, L.J. (2008): Influence of bioclimatic variables on tree-line conifer distribution in the Greater Yellowstone Ecosystem: implications for species of conservation concern. - Journal of Biogeography 35(4): 698-710.

[361] Schultheis, E.H., Hopfensperger, K.N., Brenner, J.C. (2010): Potential Impacts of Climate Change on Sphagnum Bogs of the Southern Appalachian Mountains. - Natural Areas Journal 30(4): 417-424.

[362] Schuur, E.A.G., Crummer, K.G., Vogel, J.G., Mack, M.C. (2007): Plant Species Composition and Productivity following Permafrost Thaw and Thermokarst in Alaskan Tundra. - Ecosystems 10: 280-292.

[363] Schwinning, S., Sala, O.E. (2004): Hierarchy of responses to resource pulses in arid and semi-arid ecosystems. - Oecologia 141: 211-220. 
[364] Schwinning, S., Starr, B.I., Ehleringer, J.R. (2005): Summer and winter drought in a cold desert ecosystem (Colorado Plateau) part I: effects on soil water and plant water uptake. Journal of Arid Environments 60: 547-566.

[365] Scott, D., Malcolm, J.R., Lemieux, C. (2002) : Climate change and modelled biome representation in Canada's national park system: implications for system planning and park mandates. - Global Ecology and Biogeography 11(6): 475-484.

[366] Seager, R., Ting, M., Held, I., Kushnir, Y., Lu, J., Vecchi, G., Huang, H.P., Harnik, N., Leetmaa, A., Lau, N.C., Li, C., Velez, J., Naik, N. (2007): Model projections of an imminent transition to a more arid climate in Southwestern North America. - Science 316: 1181-1184.

[367] Serreze, M.C., Walsh, J.E., Chapin, F.S. III, Osterkamp, T., Dyurgerov, M., Romanovsky, V., Oechel, W.C., Morison, J., Zhang, T., Barry, R.G. (2000): Observational evidence of recent change in the northern high-latitude environment. Climatic Change 46: 159-207.

[368] Shafer, S.L., Bartlein, P.J., Thompson, R.S. (2001): Potential Changes in the Distributions of Western North America Tree and Shrub Taxa under Future Climate Scenarios. - Ecosystems 4: 200-215.

[369] Shao, G., Shugart, H.H., Young, D.R. (1995): Simulation of transpiration sensitivity to environmental changes for shrub (Myrica cerifera) thickets on a Virginia barrier island. Ecological Modelling 78: 235-248.

[370] Shaver, G.R., Chapin III, F.S., Gartner, B.L. (1986): Factors limiting seasonal growth and peak biomass accumulation in Eriophorum vaginatum in Alaskan tussock tundra. Journal of Ecology 74: 257-278.

[371] Shaver, G.R., Billings, W.D., Chapin III, F.S., Giblin, A.E., Nadelhoffer, K.J., Oechel, W.C., Rastetter, E.B. (1992): Global change and the carbon balance of arctic ecosystems. - BioScience 61: 415-435.

[372] Shaver, G.R., Johnson, L.C., Cades, D.H., Murray, G., Laundre, J.A., Rastetter, E.B., Nadelhoffer, K.J., Giblin, A.E. (1998): Biomass and CO2 flux in wet sedge tundras: responses to nutrients, temperature, and light. - Ecol. Monogr. 68(1): 75-97.

[373] Shaver, G.R., Bret-Harte, S.M., Jones, M.H., Johnstone, J., Gough, L., Laundre, J., Chapin, F.S. (2001): Species composition interacts with fertilizer to control long-term change in tundra productivity. - Ecology 82: 3163-3181.

[374] Shaw, M.R., Harte, J. (2001): Nitrogen cycling in a subalpine ecotone exposed to simulated climate change: differential responses of two soil microclimates. - Global Change Biology 7: 193-210.

[375] Sher, A.A., Goldberg, D.E., Novoplansky, A. (2004): The effect of mean and variance in resource supply on survival of annuals from Mediterranean and desert environments. Oecologia 141: 353-362.

[376] Shirley, L.J., Battaglia, L.L. (2006): Assessing vegetation change in coastal landscapes of the Northern Gulf of Mexico. - Wetlands 26(4): 1057-1070.

[377] Silapaswan, C.S., Verbyla, D.L., McGuire, A.D. (2001): Land cover change on the Seward Peninsula: the use of remote sensing to evaluate the potential influences of climate warming on historical vegetation dynamics. - Can. J. Remote Sens. 27: 542-554.

[378] Silva, L.C.R., Sternberg, L., Haridasan, M., Hoffmann, W.A., Miralles-Wilhelm, F., Franco, A.C. (2008): Expansion of gallery forests into central Brazilian savannas. Global Change Biol. 14: 1-11.

[379] Silva, L.C.R., Anand, M., Oliveira, J.M., Pillar, V.D. (2009): Past century changes in Araucaria angustifolia (Bertol.) Kuntze water use efficiency and growth in forest and grassland ecosystems of southern Brazil: implications for forest expansion. - Global Change Biology 5: 2387-2396.

[380] Silva, L.C.R., Haridasan, M., Sternberg, L.S.L., Franco, A.C., Hoffmann, W.A. (2010): Not all forests are expanding over central Brazilian savannas. - Plant Soil 333: 431-442. 
[381] Silva, L.C.R., Anand, M. (2011): Mechanisms of Araucaria (Atlantic) Forest Expansion into Southern Brazilian Grasslands. - Ecosystems 14: 1354-1371.

[382] Silva, L.C.R., Giorgis, M., Anand, M., Enrinco, L., Perez-Harguindeguy, N., Falczuk, V., Tieszen, L.L., Cabido, M. (2011): Late Holocene shift in C4 species range in central Argentina. - Plant and Soil doi:10.1007/s11104-011-0868-x.

[383] Simonin, K., Kolb, T.E., Montes-Helu, M., Koch, G.W. (2006): Restoration thinning and influence of tree size and leaf area to sapwood area ratio on water relations of Pinus ponderosa. - Tree Physiol. 26: 493-503.

[384] Simpson, R.L., Good, R.E., Leck, M.A., Whigham, D.F. (1983): The ecology of freshwater tidal wetlands. - Bioscience 33: 255-259.

[385] Sklar, F.H., van der Valk, A. (eds.) (2003): Tree Islands of the Everglades. Kluwer Academic Publishers, Boston.

[386] Smith, S.D., Monson, R.K., Anderson, J.E. (1997): Physiological ecology of North American desert plants. - Springer-Verlag, Berlin.

[387] Smith, S.D., Huxman, T.E., Zitzer, S.F., Charlet, T.N., Housman, D.C., Coleman, J.S., Fenstermaker, L.K., Seeman, J.R., Nowak, R.S. (2000): Elevated $\mathrm{CO}_{2}$ increases productivity and invasive species success in an arid ecosystem. - Nature 40: 79-82.

[388] Snyder, K.A., Tartowski, S.L. (2006): Multi-scale temporal variation in water availability: Implications for vegetation dynamics in arid and semi-arid ecosystems. Journal of Arid Environments 65: 219-234.

[389] Solomon, A.M. (1986): Transient response of forests to CO2-induced climate change: simulation modeling experiments in eastern North America. - Oecologia 68: 567-579.

[390] Solomon, S., Plattner, G.-K., Knutti, R., Friedlingstein, P. (2009): Irreversible climate change due to carbon dioxide emissions. - Proc. Nat. Acad. Sci. USA 106: 1704-1709.

[391] Sponseller, R.A. (2007): Precipitation pulses and soil $\mathrm{CO}_{2}$ flux in an Sonoran Desert ecosystem. - Global Change Biol. 13: 426-436.

[392] Stafford, J.M., Wendler, G., Curtis, J. (2000): Temperature and precipitation of Alaska: 50 year trend analysis. - Theoretical and Applied Climatology 67: 33-44.

[393] Starfield, A.M., Chapin, F.S. III (1996): Model of transient changes in arctic and boreal vegetation in response to climate and land use change. - Ecol. Appl. 6: 842-864.

[394] Sternberg, L., Swart, P.K. (1987): Utilization of freshwater and ocean water by coastal plants of Southern Florida. - Ecology 68: 1898-1905.

[395] Sternberg, M., Brown, V.K., Masters, G.J., Clarke, I.P. (1999): Plant community dynamics in a calcareous grassland under climate change manipulation. - Plant Ecol. 143: $29-37$.

[396] Sternberg, da L. S.L., Teh, S.Y., Ewe, S.M.L., Miralles-Wilhelm, F., DeAngelis, D.L. (2007): Competition between Hardwood Hammocks and Mangroves. - Ecosystems 10: 648-660.

[397] Stocks, B.J., Fosberg, M.A., Lynham, T.J., Mearns, L., Wotton, B.M., Yang, Q., Jin, J.Z., Lawrence, K., Hartley, G.R., Mason, J.A., McKenney, D.W. (1998): Climate change and forest fire potential in Russian and Canadian boreal forests. - Clim. Change 38: 1-13.

[398] Stow, D.A., Hope, A., McGuire, D., Verbyla, D., Gamon, J., Huemmrich, F., Houston, S., Racine, C., Sturm, M., Tape, K., Hinzman, L., Yoshikawa, K., Tweedie, C., Noyle, B., Silapaswan, C., Douglas, D., Griffith, B., Jia, G., Epstein, H., Walker, D., Daeschner, S., Petersen, A., Zhou, L.M., Myneni, R. (2004): Remote sensing of vegetation and landcover change in Arctic tundra ecosystems. - Remote Sens. Environ. 89: 281-308.

[399] Strack, J.E., Pielke, R.A. Sr., Liston, G.E. (2007): Arctic tundra shrub invasion and soot deposition: consequences for spring snowmelt and near-surface air temperatures. - J. Geophys. Res. 112: G04S44.

[400] Stromberg, J.C., Lite, S.J., Dixon, M.D. (2010): Effects of stream flow patterns on riparian vegetation of a semiarid river: implications for a changing climate. - River Research and Applications 26(6): 712-729. 
[401] Sturm, M., McFadden, J.P., Liston, G.E., Chapin, F.S., Racine, C.H., Holmgren, J. (2001a): Snow-shrub interactions in Arctic tundra: a hypothesis with climatic implications. - J. Clim. 14: 336-344.

[402] Sturm, M., Racine, C., Tape, K. (2001b): Climate change-increasing shrub abundance in the Arctic. - Nature 411: 546-547.

[403] Suarez, M.L., Kitzberger, T. (2008): Recruitment patterns following a severe drought: long-term compositional shifts in Patagonian forests. - Canadian Journal of Forest Research-Revue Canadienne de Recherche Forestiere 38(12): 3002-3010.

[404] Suazo, A.A., Spencer, J.E., Engel, E.C., Abella, S.R. (2012): Responses of native and non-native Mojave Desert winter annuals to soil disturbance and water additions. - Biol. Invasions 14: 215-227.

[405] Suffling, R. (1995): Can disturbance determine vegetation distribution during climate warming? A boreal test. - J. Biogeogr. 22: 501-508.

[406] Suffling, R., Scott, D. (2002): Assessment of climate change effects on Canada's national park system. - Environmental Monitoring and Assessment 74: 117-139.

[407] Suttle, K.B., Thomsen, M.A., Power, M.E. (2007): Species interactions reverse grassland responses to changing climate. - Science 315(5812): 640-642.

[408] Svejcar, T., Bates, J., Angell, R., Miller, R. (2003): The influence of precipitation timing on the sagebrush steppe ecosystem. - In: McPherson, G., Weltzin, J. (eds.) Changing Precipitation Regimes \& Terrestrial Ecosystems, University of Arizona Press, Tucson, AZ.

[409] Swemmer, A.M., Knapp, A.K., Snyman, H.A. (2007): Intra-seasonal precipitation

[410] patterns and above-ground productivity in three perennial grasslands. - J. Ecol. 95: 780788.

[411] Szentes Sz., Házi J., Bartha S., Sutyinszki Zs., Penksza K. (2010): Comparative researches on resilience of species composition and biomass productivity in pastures and hayfield of the Balataon Uplands, Hungary. Növénytermelés 59: 349-352.

[412] Szentes Sz., Sutyinszki Zs., Zimmermann Z., Szabó G., Járdi I., Házi J., Penksza K., Bartha S. (2011a): A fenyérfü (Bothriochloa ischaemum (L.) Keng 1936) gyep béta-diverzitására gyakorolt hatásainak vizsgálata és értékelése mikrocönológiai módszerekkel. Tájökológiai Lapok 9(2):.463-475.

[413] Szentes Sz., Dannhauser C., Coetzee R., Penksza K. (2011b): Biomass productivity, nutrition content and botanical investigation of Hungarian Grey cattle pasture in Tapolca basin. AWETH 7(2): 180-198.

[414] Tang, G.P., Beckage, B. (2010): Projecting the distribution of forests in New England in response to climate change. - Diversity and Distributions 16(1): 144-158.

[415] Tape, K., Sturm, M., Racine, C. (2006): The evidence for shrub expansion in Northern Alaska and the Pan-Arctic. - Global Change Biol. 12: 686-702.

[416] Teh, S.Y., DeAngelis, D.L., Sternberg, da L. S.L., Miralles-Wilhelm, F.R., Smith, T.J., Koh, H.L. (2008): A simulation model for projecting changes in salinity concentrations and species dominance in the coastal margin habitats of the Everglades. - Ecological Modelling 213: 245-256.

[417] Tellez-Valdes, O., Davila-Aranda, P., Lira-Saade, R. (2006): The effects of climate change on the long-term conservation of Fagus grandifolia var. mexicana, an important species of the Cloud Forest in Eastern Mexico. - Biodiversity and Conservation 15(4): 1095-1107.

[418] Tilman, D., El Haddi, A. (1992): Drought and biodiversity in Grasslands. - Oecologia 98: 257-264.

[419] Trejo, I., Martinez-Meyer, E., Calixto-Perez, E., Sanchez-Colon, S., de la Torre, R.V. (2011): Analysis of the effects of climate change on plant communities and mammals in Mexico. - Atmosfera 24(1) SI: 1-14. 
[420] Urban, D.L., Miller, C., Halpin, P.N., Stephenson, N.L. (2000): Forest gradient response in Sierran landscapes: the physical template. - Landscape Ecology 15: 603-620.

[421] USEPA (1998): Climate Change and Indiana. - Office of Policy, EPA 236-F-98-007g

[422] Valle-Díaz, O., Blanco-García, A., Bonfil, C., Paz, H., Lindig-Cisneros, R. (2009): Altitudinal range shift detected through seedling survival of Ceiba aesculifolia in an area under the influence of an urban heat island. - Forest Ecology and Management 258: $1511-1515$.

[423] van der Valk, A.G., Davis, C.B. (1978): The role of seed banks in the vegetation dynamics of prairie glacial marshes. - Ecology 59: 322-335.

[424] Van Devender, T.R. (1995): Desert grassland history: changing climates, evolution, biogeography and community dynamics. - In: McClaran, M.P., Van Devender, T.R. (eds.) The Desert Grassland, University of Arizona Press, Tucson, AZ, USA.

[425] van Mantgem, P.J., Stephenson, N.L., Byrne, J.C., Daniels, L.D., Franklin, J.F., Fulé, P.Z., Harmon, M.E., Larson, A.J., Smith, J.M., Taylor, A.H., Veblen, T.T. (2009): Widespread increase of tree mortality rates in the Western United States. - Science 323: 521-524.

[426] van Wijk, M.T., Clemmensen, K.E., Shaver, G.R., Williams, M., Callaghan, T.V., Chapin, F.S., Cornelissen, J.H.C., Gough, L., Hobbie, S.E., Jonasson, S., Lee, J.A., Michelsen, A., Press, M.C., Richardson, S.J., Rueth, H. (2003): Long-term ecosystem level experiments at Toolik Lake, Alaska, and at Abisko, Northern Sweden: generalizations and differences in ecosystem and plant type responses to global change. Global Change Biology 10: 105-123.

[427] VEMAP participants (Melillo, J.M. and 26 others) (1995): Vegetation/ecosystem modeling and analysis project (VEMAP): comparing biogeography and biogeochemistry models in a continental-scale study of terrestrial ecosystem responses to climate change and $\mathrm{CO}_{2}$ doubling. - Global Biogeochemical Cycles 9: 407-437.

[428] Viereck, L.A. (1973): Wildfire in the taiga of Alaska. - Quat. Res. 3: 465-495.

[429] Viereck, L.A., Van Cleve, K., Dyrness, C.T. (1986): Forest ecosystem distribution in the taiga environment. - In: Van Cleve, K., Chapin III, F.S., Flanagan, P.W., Viereck, L.A., Dyrness, C.T. (eds.) Forest Ecosystems in the Alaskan Taiga: a Synthesis of Structure and Function, Springer-Verlag, New York.

[430] Von Englen, O.D. (1914): Effects of continental glaciation on agriculture. Part I. - Bull. Am. Geogr. Soc. 46: 241-264.

[431] Walker, M.D., Wahren, C.H., Hollister, R.D., Henry, G.H.R., Ahlquist, L.E., Alatalo, J.M., Bret-Harte, M.S., Calef, M.P., Callaghan, T.V., Carroll, A.B., Epstein, H.E., Jonsdottir, I.S., Klein, J.A., Magnusson, B., Molau, U., Oberbauer, S.F., Rewa, S.P., Robinson, C.H., Shaver, G.R., Suding, K.N., Thompson, C.C., Tolvanen, A., Totland, O., Turner, P.L., Tweedie, C.E., Webber, P.J., Wookey, P.A. (2006): Plant community responses to experimental warming across the tundra biome. - Proc. Natl. Acad. Sci. USA 103: $1342-1346$.

[432] Waple, A.M., Lawrimore, J.H. (2003): State of the climate in 2002. - Bull. Am. Meteorol. Soc. 84: S1-S68.

[433] Watson, E.B., Byrne, R. (2012): Recent (1975-2004) Vegetation Change in the San Francisco Estuary, California, Tidal Marshes. - Journal of Coastal Research 28(1): 51-63.

[434] Webb III, T. (1986): Is vegetation in equilibrium with climate? How to interpret lateQuaternary pollen data. - Vegetatio 67: 75-91.

[435] Webb, W.L., Lauenroth, W.K., Szarek, S.R., Kinerson, R.S. (1986): Primary production and abiotic controls in forests, grasslands, and desert ecosystems of the United States. Ecology 64: 134-151.

[436] Webb III, T. (1987): The appearance and disappearance of major vegetational assemblages: long-term vegetational dynamics in eastern North America. - Vegetatio 69: $177-187$. 
[437] Webb, T., III. (1992): Past changes in vegetation and climate: lessons for the future. - In: Peters, R.L., Lovejoy, T.E. (eds.) Global warming and biological diversity, Yale University Press, New Haven, Connecticut, USA.

[438] Webster, P.J., Holland, G.J., Curry, J.A., Chang, H.-R. (2005): Changes in tropical cyclone number, duration, and intensity in a warming environment. - Science 309: 1844 1846.

[439] Weiss, J.L., Castro, C.L., Overpeck, J. (2009): Distinguishing pronounced droughts in the Southwestern United States: seasonality and effects of warmer temperatures. - J. Clim. 22: 5918-5932.

[440] Weltzin, J.F., McPherson, G.R. (2000a): Implications of Precipitation Redistribution for Shifts in Temperate Savanna Ecotones. - Ecology 81(7): 1902-1913.

[441] Weltzin, J.F., Pastor, J., Harth, C., Bridgham, S.D., Updegraff, K., Chapin, C.T. (2000b): Response of Bog and Fen Plant Communities to Warming and Water-Table Manipulations. - Ecology 81(12): 3464-3478.

[442] Weltzin, J.F., Loik, M.E., Schwinning, S., Williams, D.G., Fay, P.A., Haddad, B.M., Harte, J., Huxman, T.E., Knapp, A.K., Lin, G., Pockman, W.T., Shaw, M.R., Small, E.E., Smith, M.D., Smith, S.D., Tissue, D.T., Zak, J.C. (2003): Assessing the response of terrestrial ecosystems to potential changes in precipitation. - Bioscience 53: 941-952.

[443] Williams, J.W., Webb, T., Richard, P.H., Newby, P. (2000): Late quaternary biomes of Canada and the eastern United States. - J. Biogeography 27: 585-607.

[444] Williams, J.W., Jackson, S.T. (2007): Novel climates, no-analog communities, and ecological surprises. - Front. Ecol. Env. 5: 475-482.

[445] Wirth, C., Lichstein, J.W., Dushoff, J., Chen, A., Chapin, F.S. (2008): White spruce meets black spruce: dispersal, postfire establishment, and growth in a warming climate. Ecological Monographs 78: 489-505.

[446] Woodhouse, C.A., Overpeck, J.T. (1998): 2000 years of drought variability in the central United States. - Bull. Am. Meteorol. Soc. 79: 2693-2714.

[447] Woodward, F. (1987): Climate and Plant Distribution. - Cambridge University Press, Cambridge.

[448] Wright, J.P., Fridley, J.D. (2010): Biogeographic synthesis of secondary succession rates in Eastern North America. - Journal of Biogeography 37: 1584-1596.

[449] Young, J.A., Evans, R.A., Eckert, R.E., Key, B.L. (1987): Cheatgrass. - Rangelands 9: 266-270.

[450] Yurkonis, K.A., Meiner, S.J. (2006): Drought impacts and recovery are driven by local variation in species turnover. - Plant Ecology 184: 325-336.

[451] Zabinski, C., Davis, M.B. (1989): Hard times ahead for Great Lakes Forests: a climate threshold model predicts responses to $\mathrm{CO}_{2}$-induced climate change. - In: Smith, J.B., Tirpak, D.A. (eds.) The Potential Effects of Global Climate Change on the United States, Appendix D: Forests, US EPA, Washington, DC.

[452] Zacarias-Eslava, Y., del Castillo, R.F. (2010): Temperate plant communities in the Sierra Juarez, Oaxaca: altitudinal levels and possible implications associated with climate change. - Boletin de la Sociedad Botanica de Mexico 87: 13-28.

[453] Zavaleta, E.S., Shaw, M.R., Chiariello, N.R., Thomas, B.D., Cleland, E.E., Field, C.B., Mooney, H.A. (2003): Grassland Responses to Three Years of Elevated Temperature, $\mathrm{CO}_{2}$, Precipitation, and N Deposition. - Ecological Monographs 73(4): 585-604.

[454] Zhao, S.Q., Da, L.J., Tang, Z.Y., Fang, H.J., Song, K., Fang, J.Y. (2006): Ecological consequences of rapid urban expansion: Shanghai, China. - Front. Ecol. Environ. 4: 341346.

[455] Zweig, C.L., Kitchens, W.M. (2008): Effects of landscape gradients on wetland vegetation communities: information for large-scale restoration. - Wetlands 28: 10861096.

[456] Zweig, C.L., Kitchens, W.M. (2009): Multi-state succession in wetlands: a novel use of state and transition models. - Ecology 90: 1900-1909. 